تؤكد الأدبيات التي تعرضت للأهداف التعليمية على ضرورة تخطيط الأهداف حتى يتم للفرد معرفة معالم الطريق الذي يسلكه ، فإن لم يتأكد الفرد من تحديد نهاية المكان الذي سوف يذهب إليه فإنه بلا شك سيكون معرضـــــا

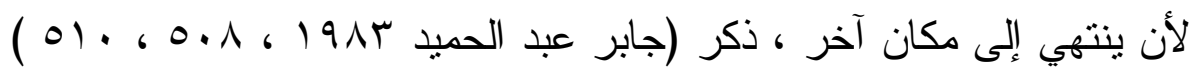

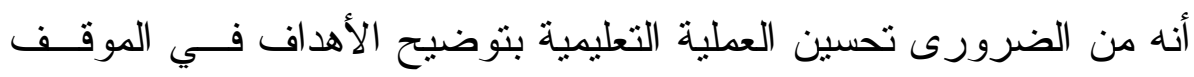

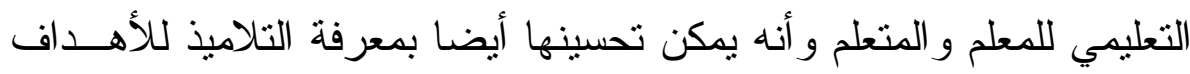
في ظل شروط معينة ، بل ذهب إلى أكثر من ذلك حيث أكد على ضــرورة

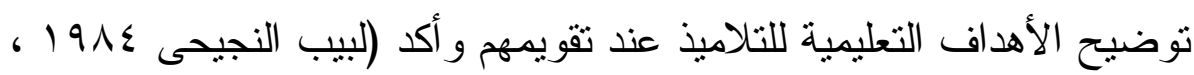

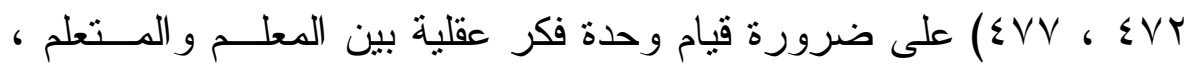
فالوضوح الفكري بينهما يساعد على نجاح التجربة ، كما أن التجربة بدورها تزيد من وضوح الفكر وتمنحه قوة وخصوبة تؤثز ا في الو اقع وتتأثز ا بــهـ ، و هناك ضرورة ملحة لأن يكون لدى معلم التربية الفنية وتلاميذه فكر مبصر ، وبصر فكرى بيتطيعان بهما أن يدركا الأهداف الو اجب تحقيقها في المو اقف التعليمية ، خاصة أن أهداف التربية الفنية يمكن الاستدلال عليهــا بصــريا

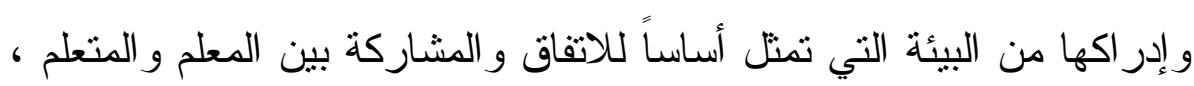
لكونها مصدر أساسى للتعليم و التعلم حينما يستشعر ها كل منهما وينفعلا بهــا كمصدر من مصادر القيم الجمالية الأصيلة و الجوهرية التى يمكن أن يكــون

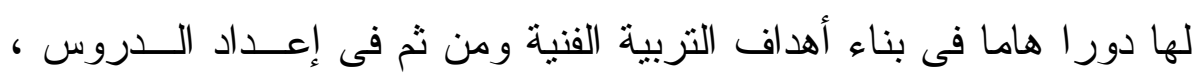

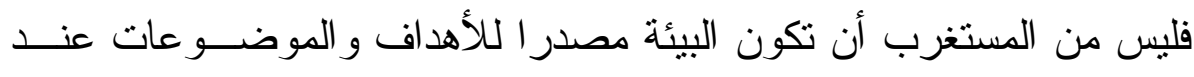
إعداد الدروس ، ولكن المستغرب هو التسليم بأن المعلمين و المشرفين علـى لـى تدريس التزبية الفنية هم مصدر الأهداف و الموضـــوعات التـي يجــب أن 
يمارسها المتعلم ، فهم بذلك يتجاهلون المتعلم الذي أصبح في موقف يجهــل

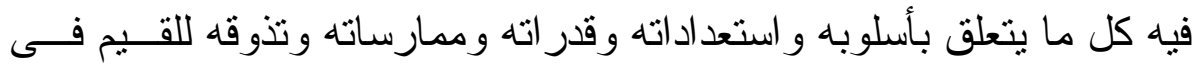

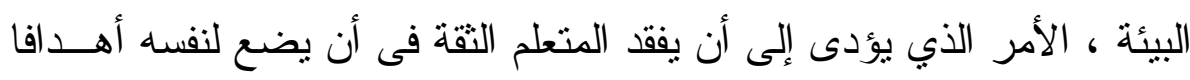

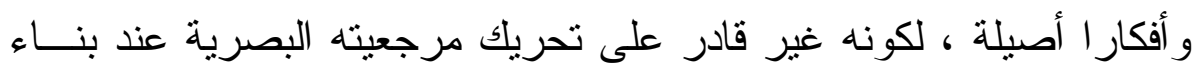

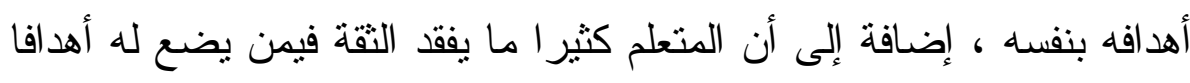

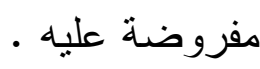
إن الطالب المعلم يخطأ أيضا حينما يضع أهدافا فى كر ساسة تحضيره

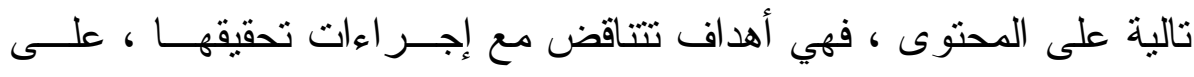

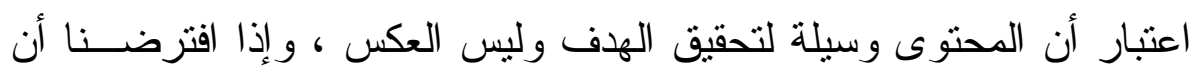

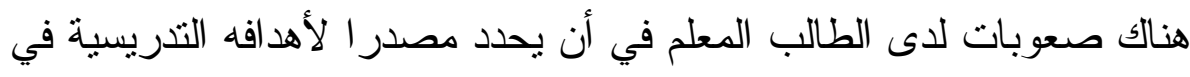

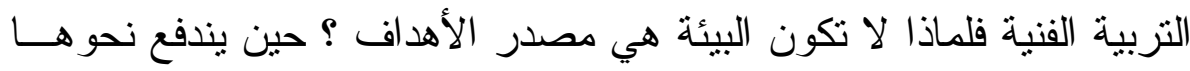

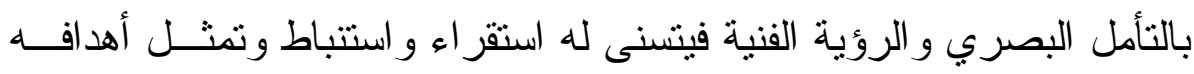

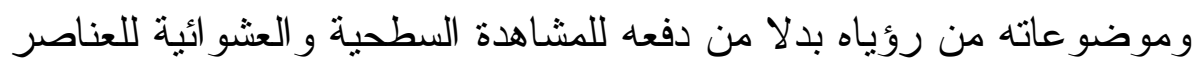

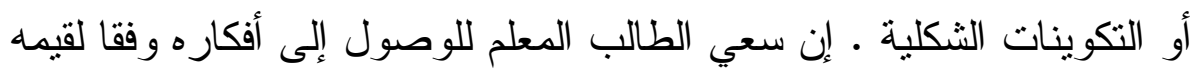

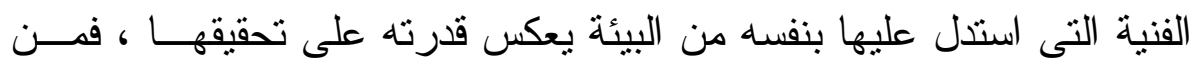
الطبيعى و المنطقي أن يمتلك منتج الهدف إجر اءات تحقيقه.

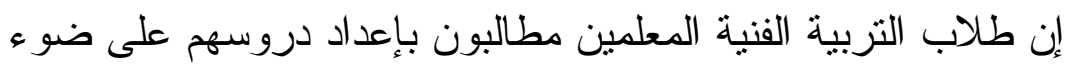

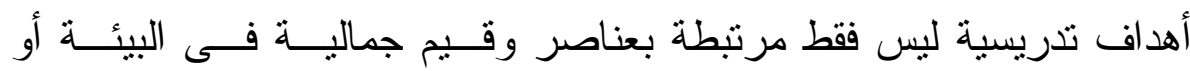

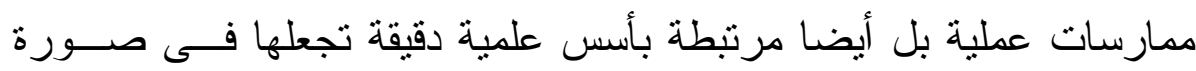

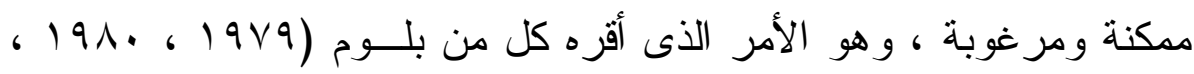

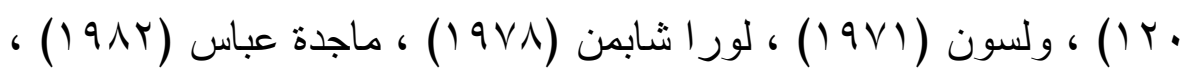

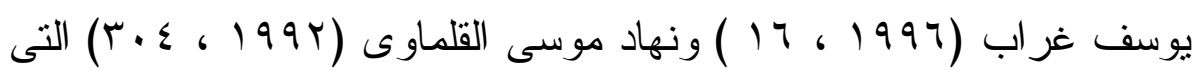


أبدت الدهشة من مشكلة التفكير غير الواضح و المضطرب بشأن الأهداف من

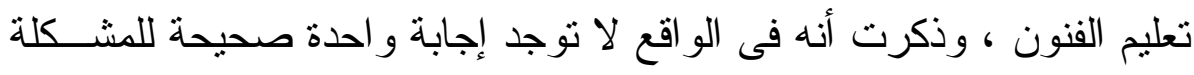
الفنية ، ولكن عندما تدرك الأهداف التعليمية من الناحية الفنية وتقدر بطريقة

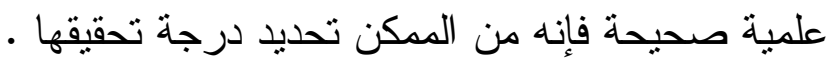

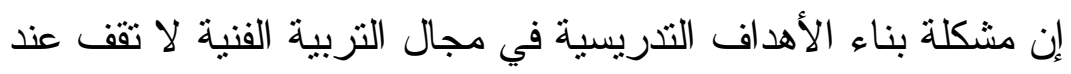

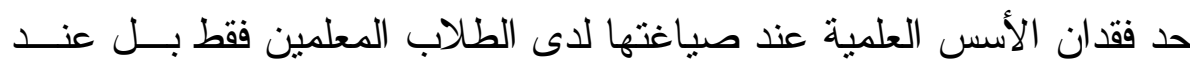

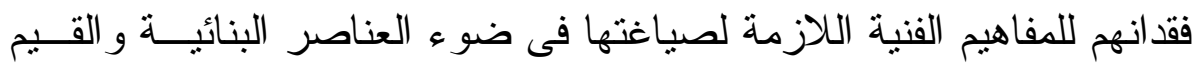

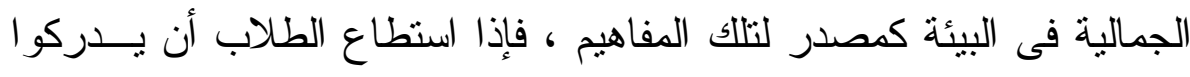

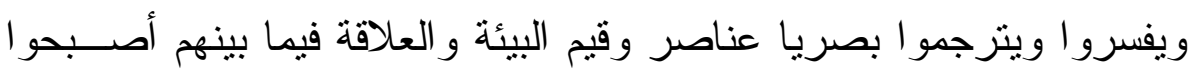

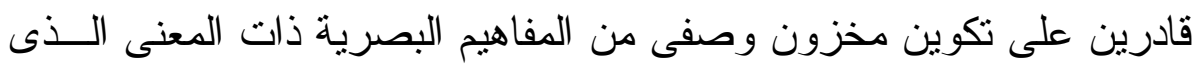

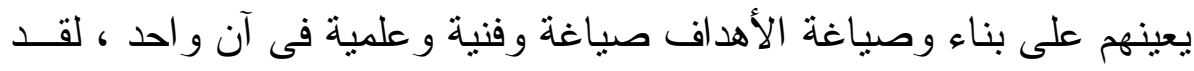

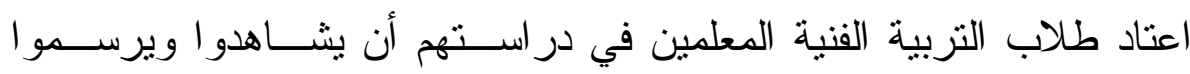

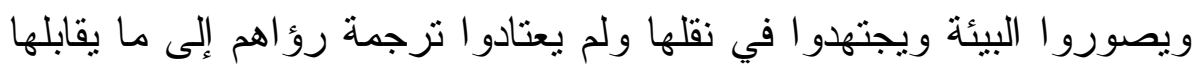

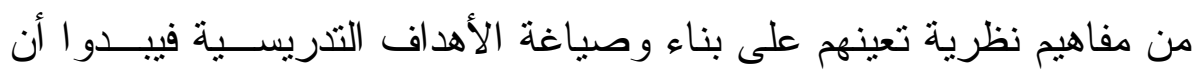

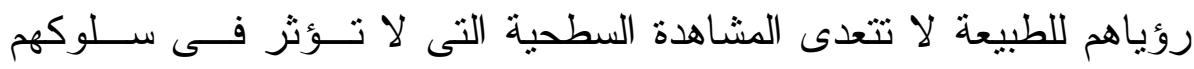

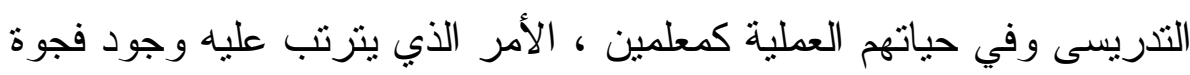

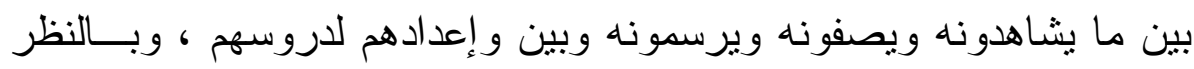

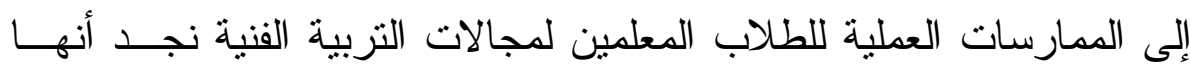

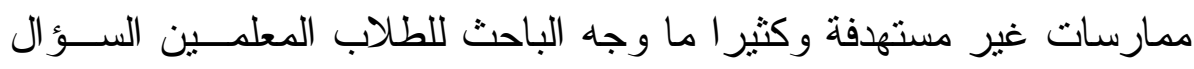
التالى : لماذا تدرسون مواد التربية الفنبة ؟ وما الفائدة التربوية التى تعـود عليكم من در اسة تلك المو اد عند إعدادكم لدروسكم فى التربيـــة الميدانيــة ؟

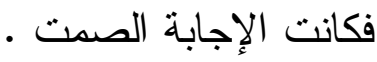


ولذا قد حرص الباحث على تحليل ما أعده الطلاب المعلىـين مسن

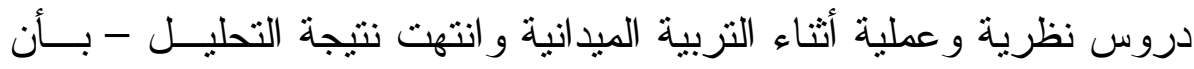

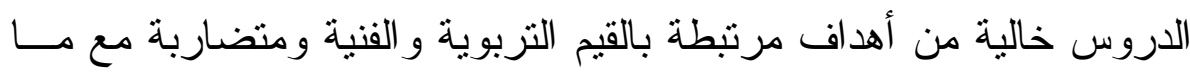

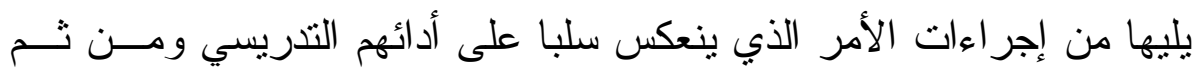

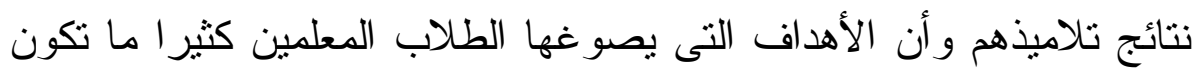

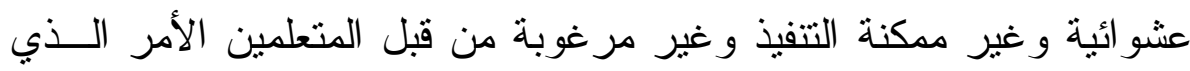

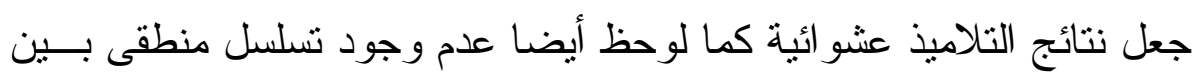

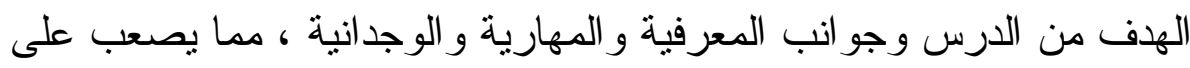

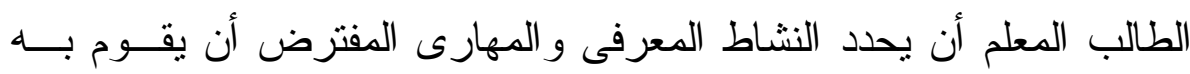

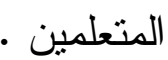

وفى ضوء ما تتحدد مشكلة الدر اسة فى التساؤل الرئيسى التالى :

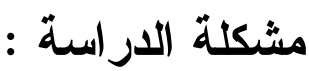

$$
\text { تتحدد مشكلة الدر اسة في التساؤل الرئيسي التالي : }
$$

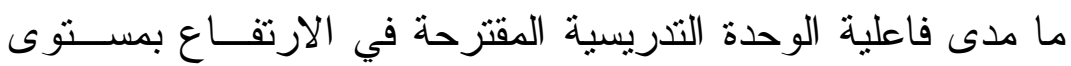

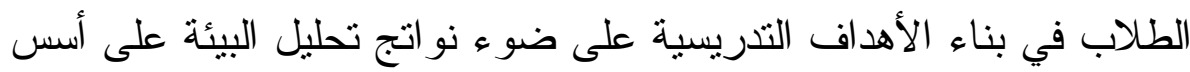
علمية ؟

ويتفرع من التساؤل الرئيسي الأسئلة الثالية :

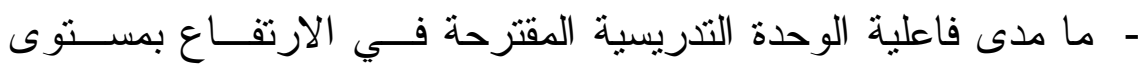
الطلاب فى تحليل البيئة على أسس علمية ؟

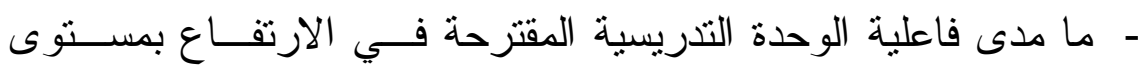

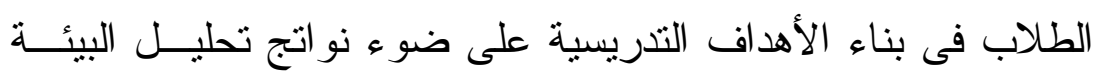

و ولى أسس علمية ؟ 


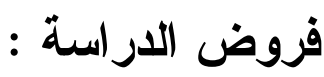

الفرض الأول : توجد فروق دالة إحصائيا عند مستوى(0 •., •)بـين

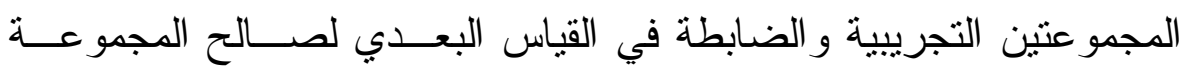

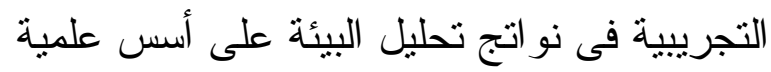

الفرض الثاني : توجد فروق دالة إحصائيا عند مستوى (0. . . •) بين

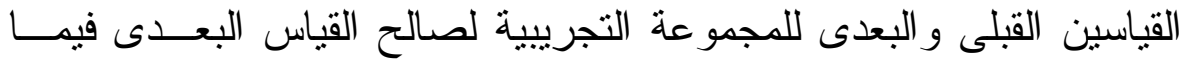

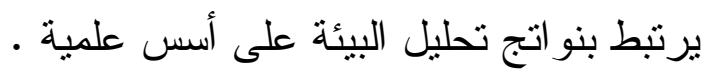

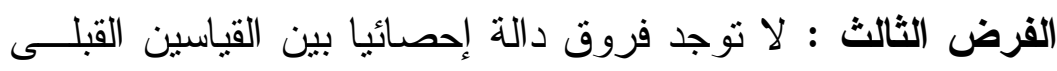

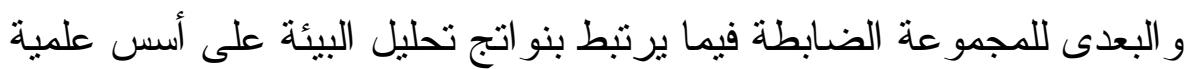

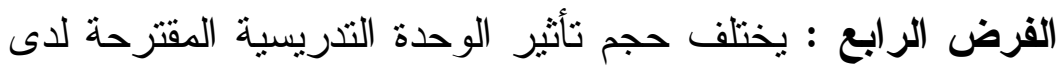

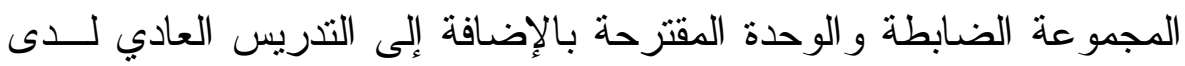
المجموعة التجريبية فيما يرتبط بنو اتج تحليل البيئة على أسس علئة المية.

الفرض الخامس : توجد فروق دالة إحصائيا عند مســتوى (0. •. , )

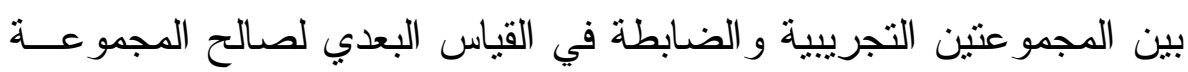

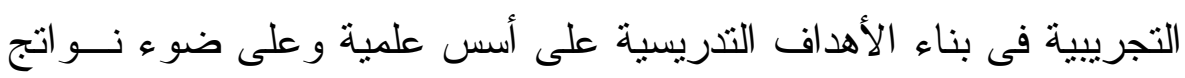
تحليل البيئة على أسس علمية. الفرض السادس : توجد فروق دالة إحصائيا عند مســتوى (0. . , )

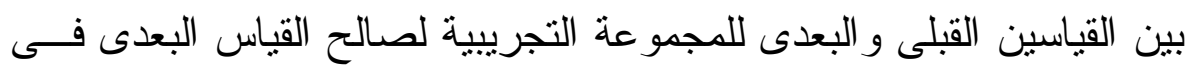

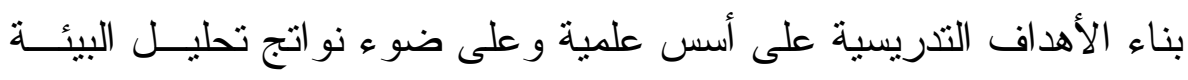

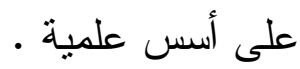




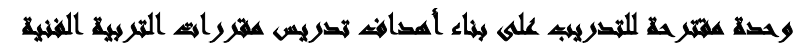

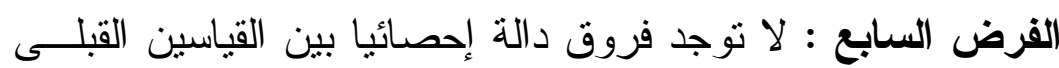

و البعدى للمجموعة الضابطة فى بناء الأهداف التذريسية على أسس على دئسـة

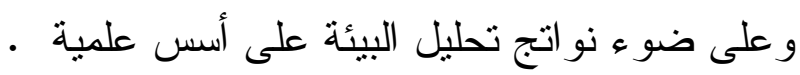

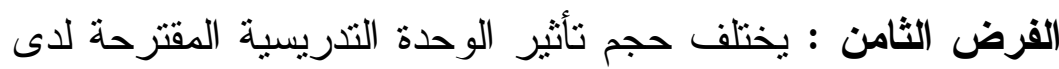

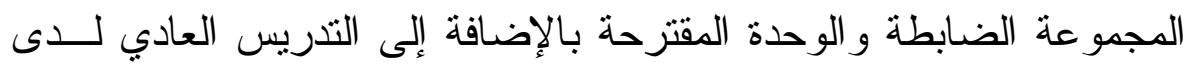

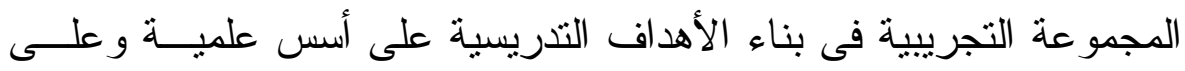

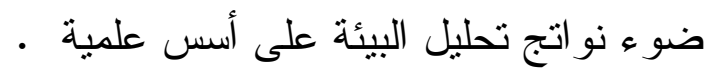

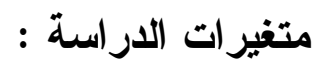

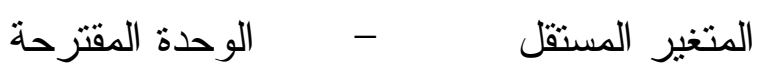

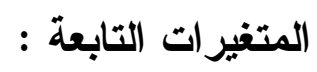

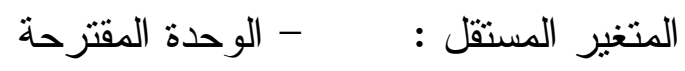

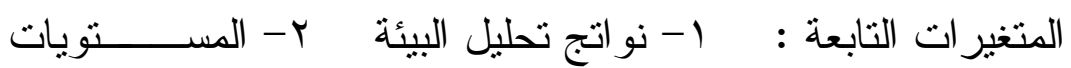

المعرفية لبلوم كأسس علمية

التصميم التجريبي :

\begin{tabular}{|c|c|c|c|}
\hline قياس بعدي & معالجات & قياس قبلي & المجموعات \\
\hline$x$ & $x$ & $x$ & تجريبية \\
\hline$x$ & التدريس العادي & $x$ & ضابطة \\
\hline
\end{tabular}

أهداف الدراسة :

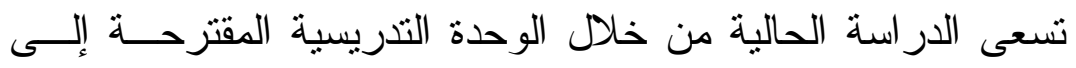

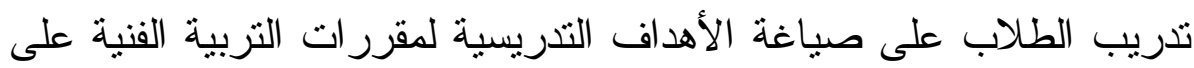

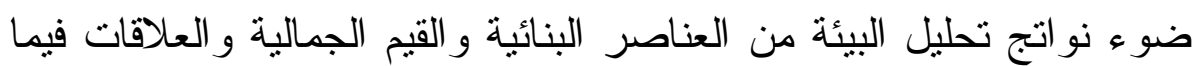

بينها و المستويات المعرفية لبلوم كأسس العلمية . 
- تمكن الدر اسة طلاب التربية الفنية وصف محتوى البيئة من العناصر

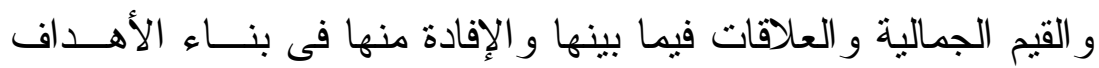

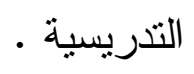

- تمكن الدراسة طلاب التزبية الفنية من الوقوف على الأسـس العلمبـــة

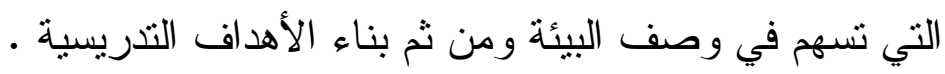

- توجه الدراسة نظر الطلاب المعلمين إلى أهمية بناء الأهداف التدريسية

عند تدريس مقررات التربية الفنية .

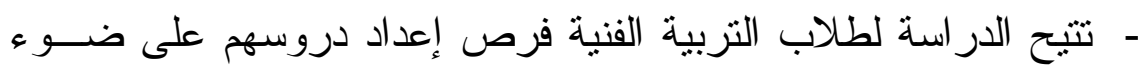

الأهداف التدريسية وما تتضمنة من جو انب معرفية ومهارية ووجدانية

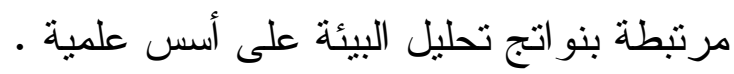

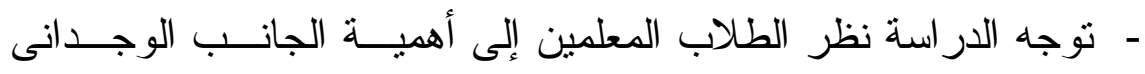

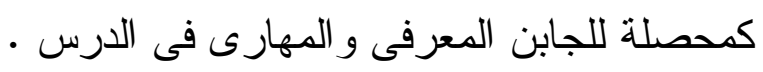

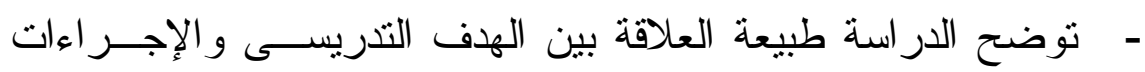

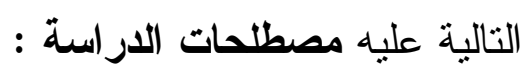

الأهداف التدريسية : يقصد بها الجمل التي يقوم الطالب المعلم بينائها

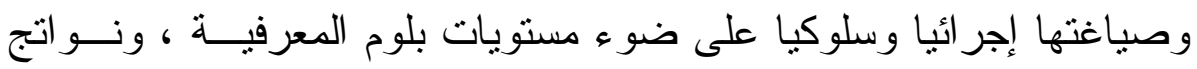

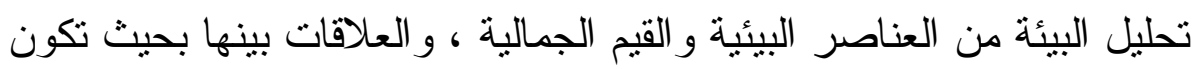

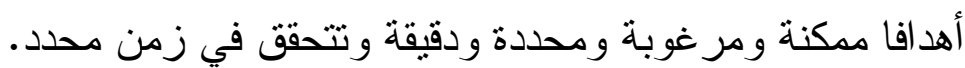

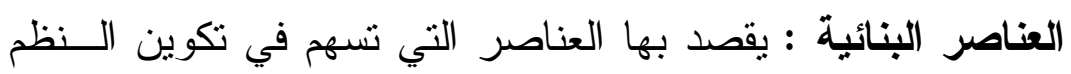

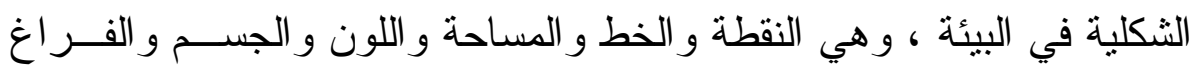


و الملمس وما بينهم من علاقات و التى يستدل عليها الطالب من تحليله للبيئــة

$$
\text { ويستخدما في بناء الأهداف التنريسية . }
$$

القيم الجمالية : ويقصد بها المعايير التى تصف مـــا تكـــن عليـــ

العناصر البنائية في البيئة من جماليات كالاتزان ، و الوحسدة ، و الســيادة ،

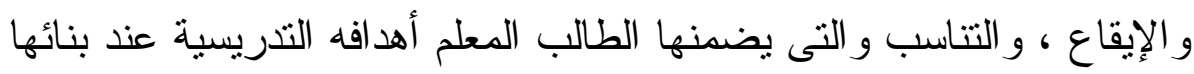

$$
\text { ومن ثم دروسه عند إعدادها. }
$$

نواتج تحليل البيئة : يقصد بها المثير ات الثكلية و القيم الجمالية وما

بينها من علاقات تحيط بالطالب المعلم ويحددها بنفسه ويثـــاهدها ويسـتنال

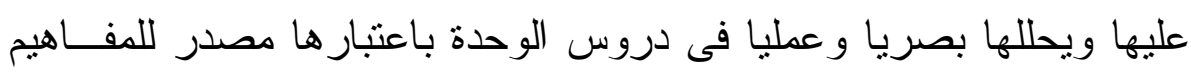
التى تعينه على بناء الأهداف التدريسية .

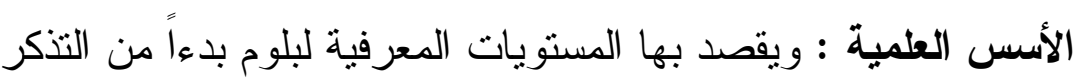

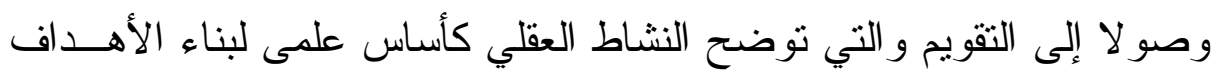

$$
\text { التذريسية }
$$

الإطار النظري والار اسات السابقة

$$
\text { الأهداف التدريسية في التربية الفنية }
$$

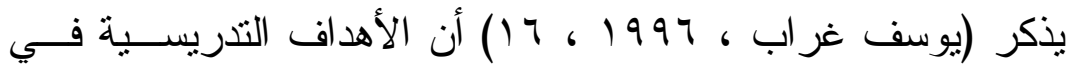

التربية الفنية تتحدد وفقا لمؤشر ات تجعلها تدريسية (إجرائية) وهي :

- أن تتضمن أدله سلوكية تحقق مدى التقدم فى عملية التعلم .

- - أن تحقق الثزجمة للأهداف التعليمية .

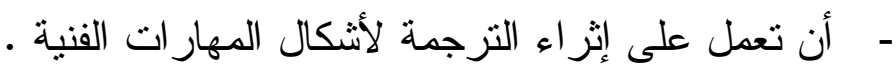

- أن تعمل على تتمية القدرة على تصنيف المادة التعليمية و الفنية . 


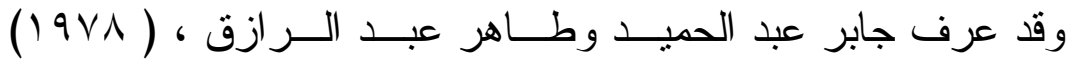

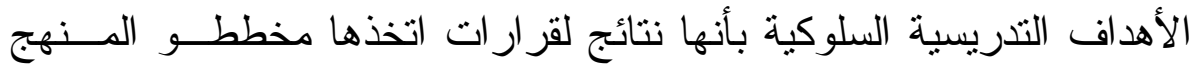

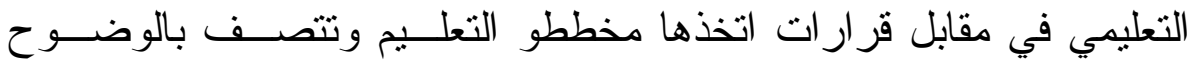

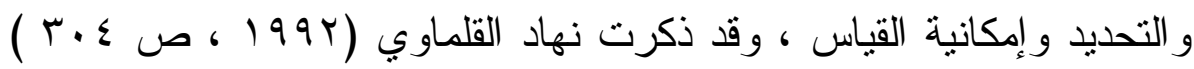

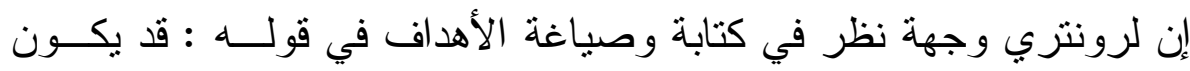

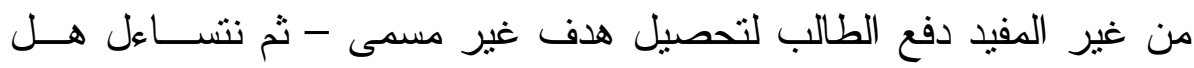

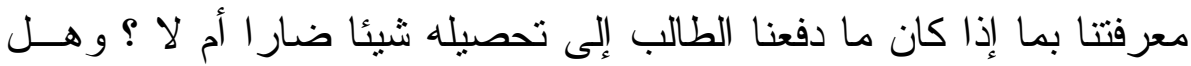

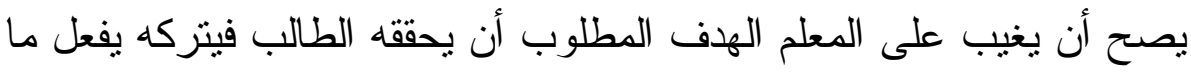

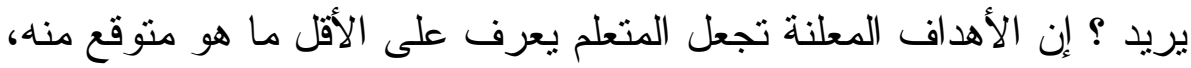

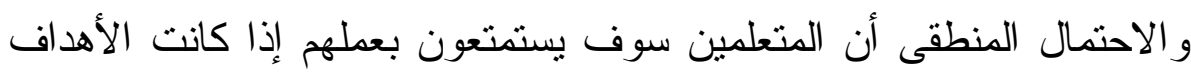

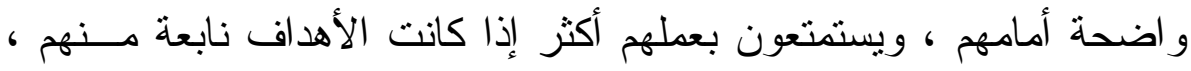

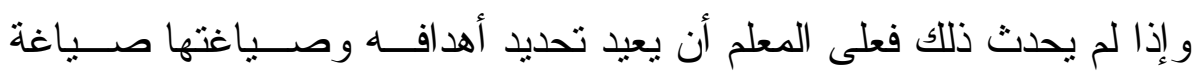

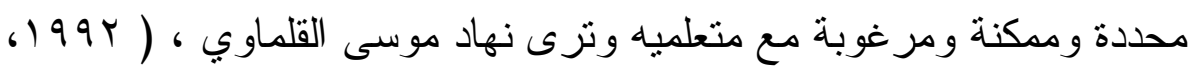

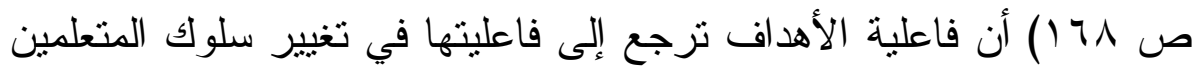

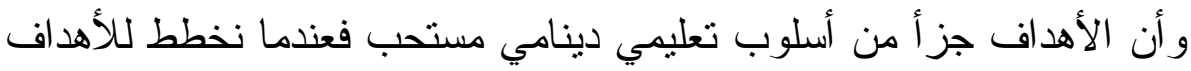

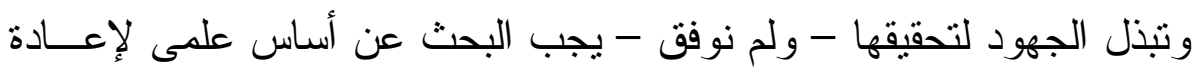

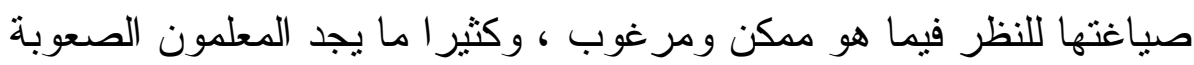

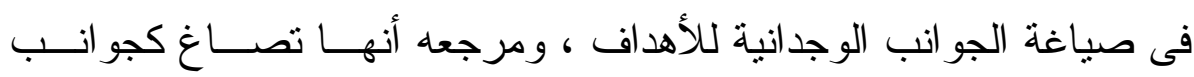

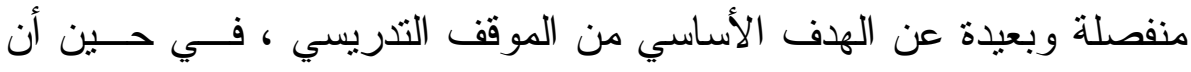

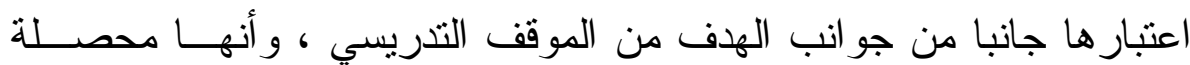

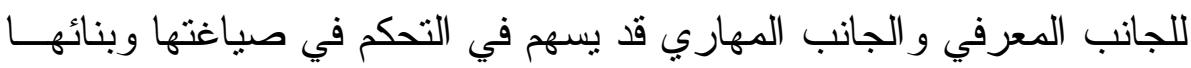

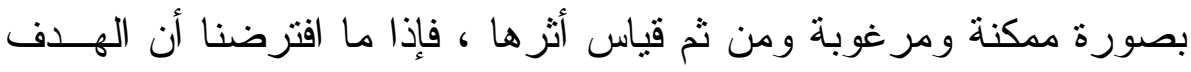


من تدريس في مجال التصميم هو : تتمية مهار ات التصميم الابتكاري لــدى

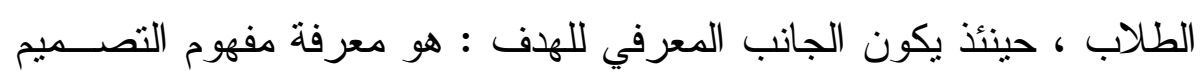

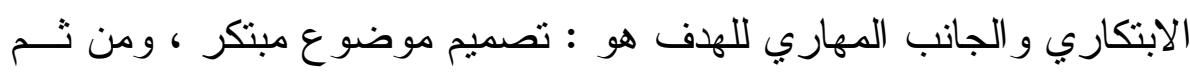

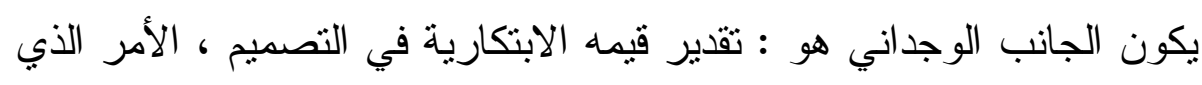

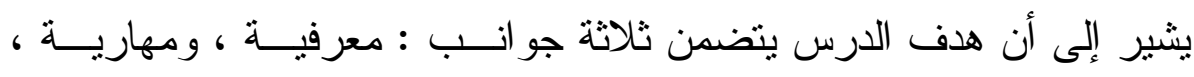

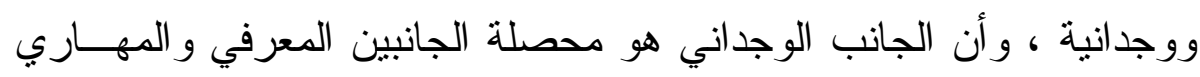

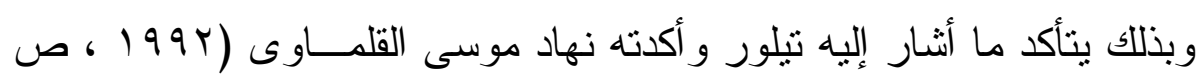

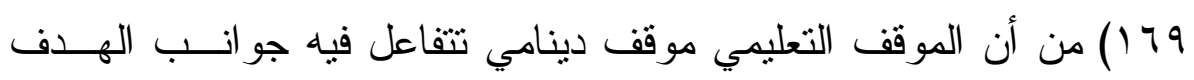

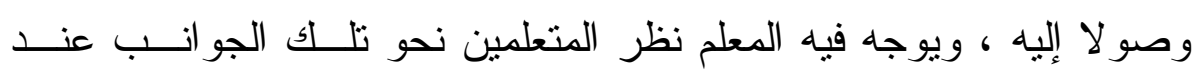

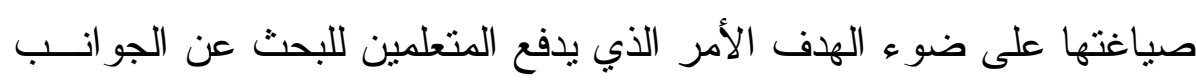

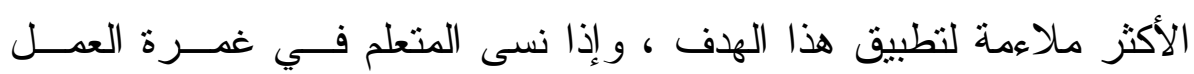

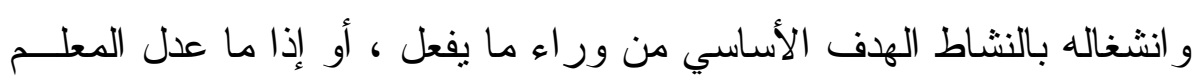
من خطته و غير من خطو اتها ، دون أن يوضح للمتعلم مغزى هذا التعـديل

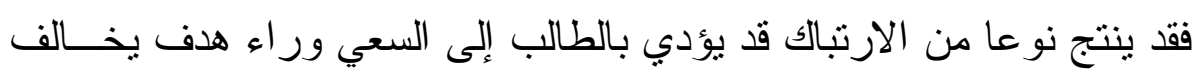
الهدف الذي قصده المعلم من العملية التعليمية . لقد أسست جهود علمية لتحديد وتصنيف الأهداف التدريسية فى مجال

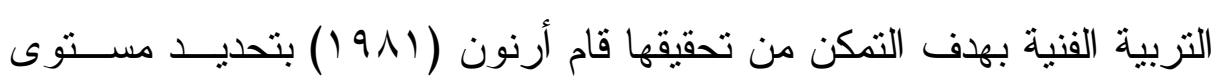

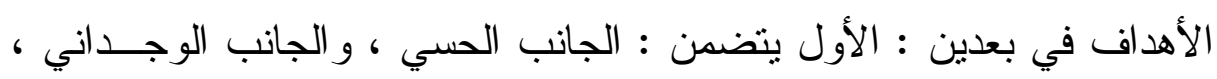

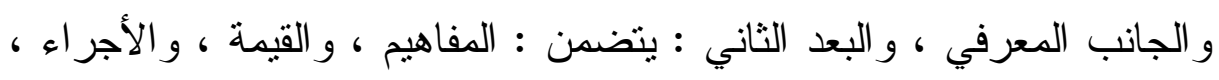
و الافتر اض ، و التقيبم و على ذلك تبنت الدر اسة الحالة تدريب الطلاب المعلمين

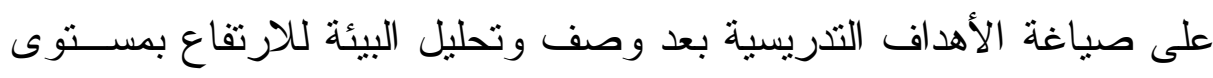
الرؤية الحس بصرية لديهم ، و إدر الك العلاقات بين العناصر الككونــــة للبيئـــة 


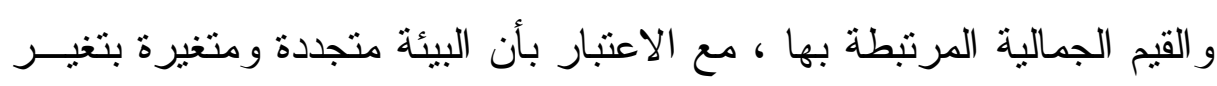

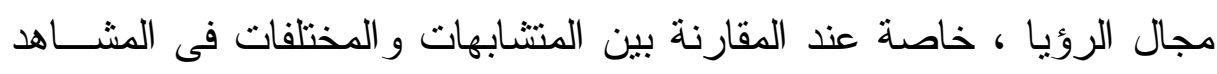

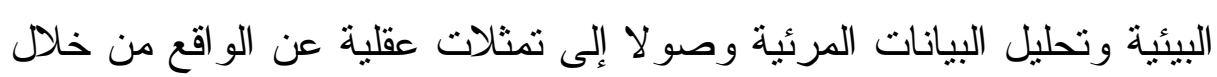

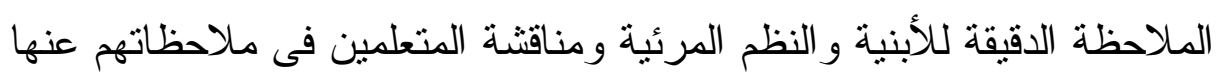

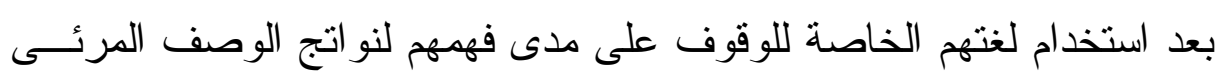

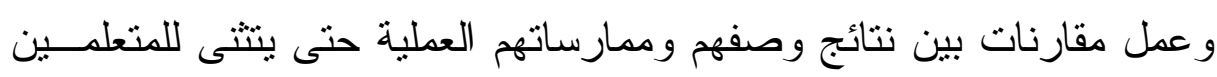

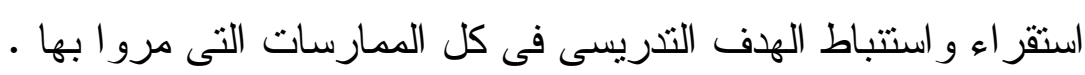

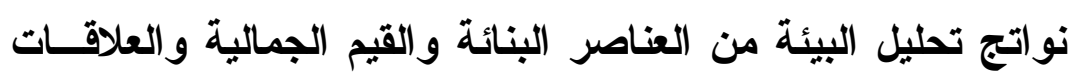

\section{فيما بينها:}

تتححور نواتج تحليل البيئة حول العناصر الثكلية و القيم الجمالية التى التى

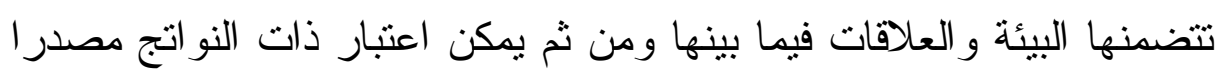

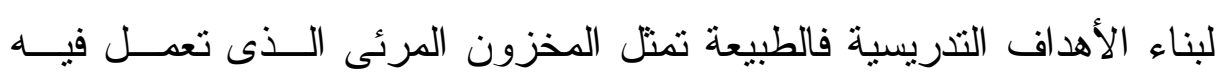
الحو اس و العقول ، و الانفعالات فالسعى المعرفى للفرد لتحليل ما تتضمنه البيئة

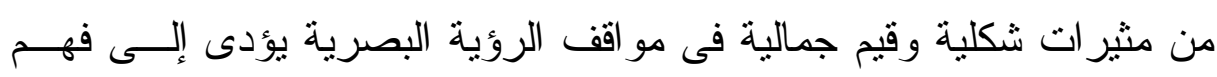

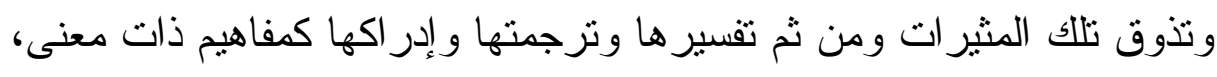

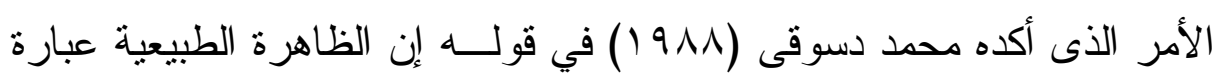

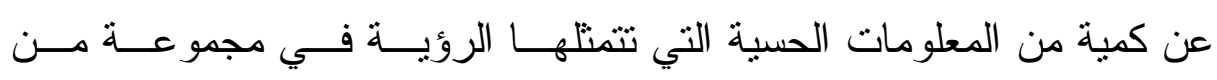

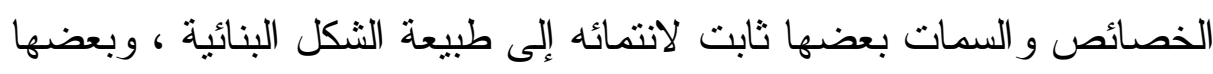

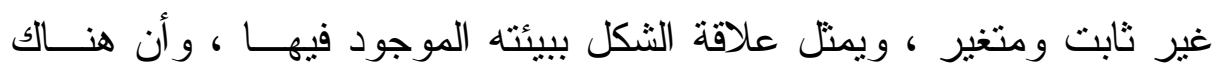

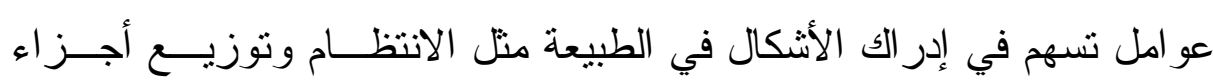

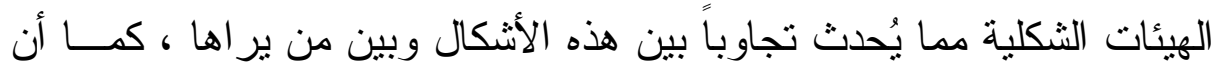

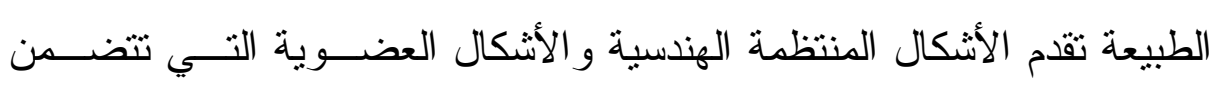




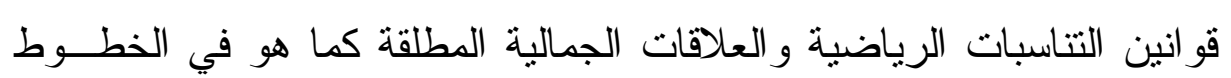

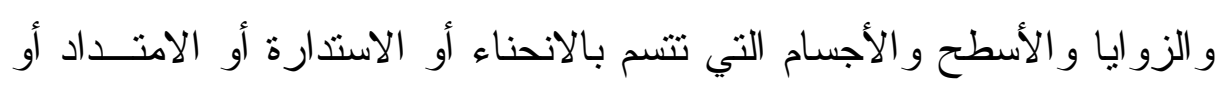

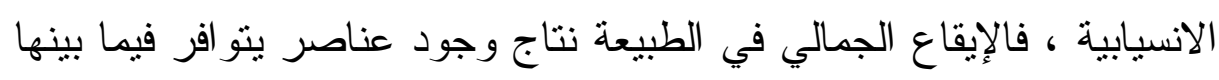

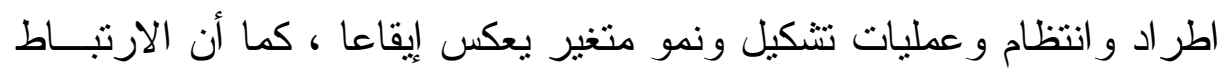

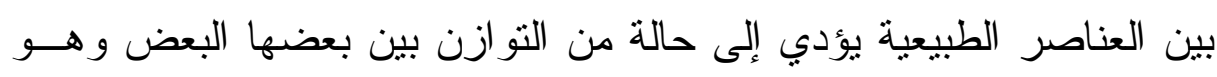

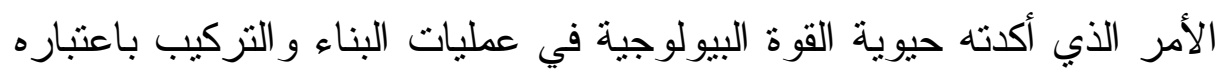

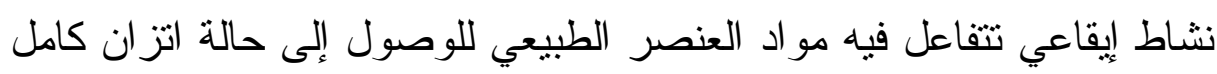

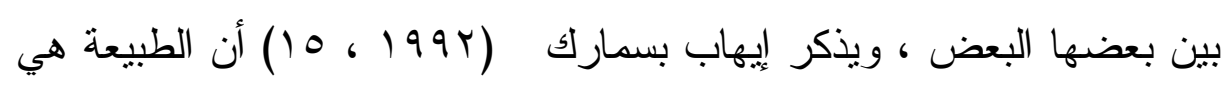

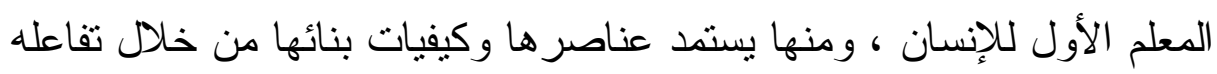

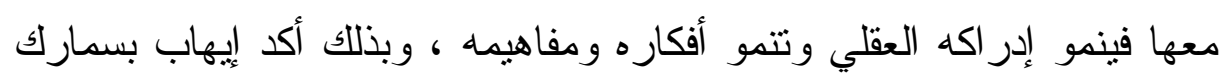

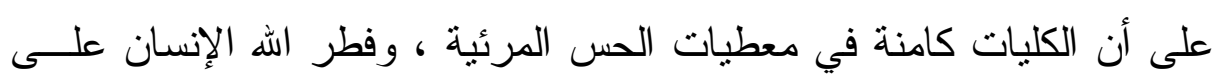

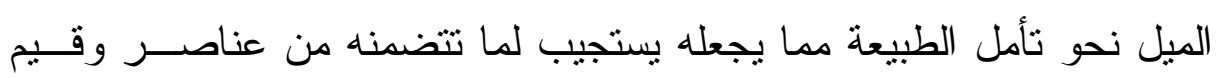

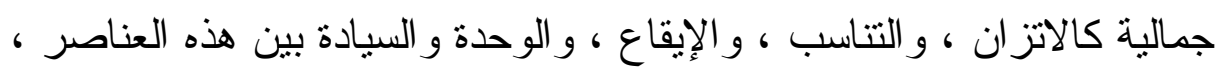

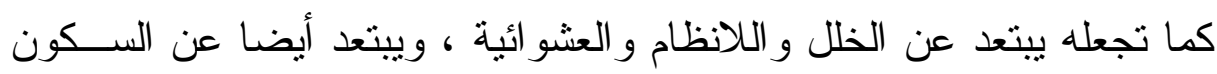

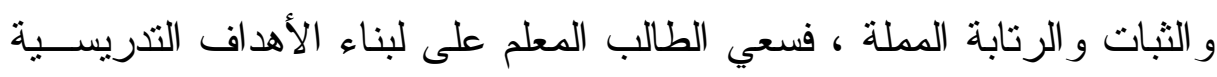

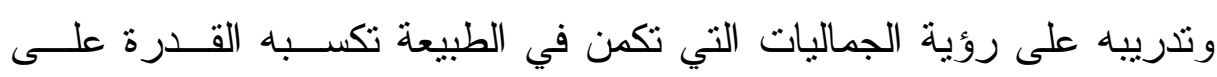

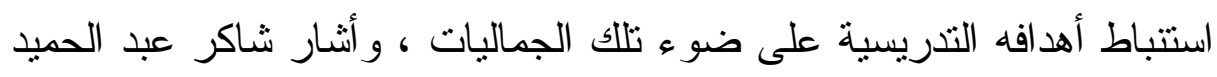

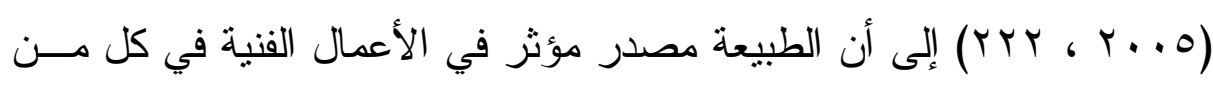

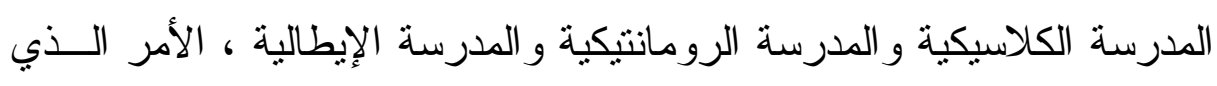

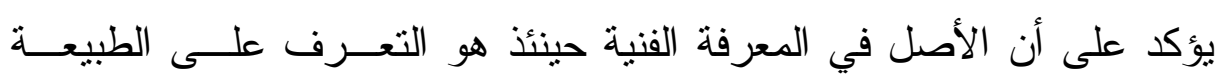

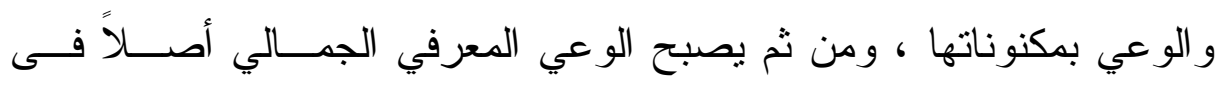

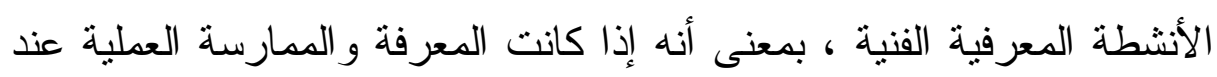




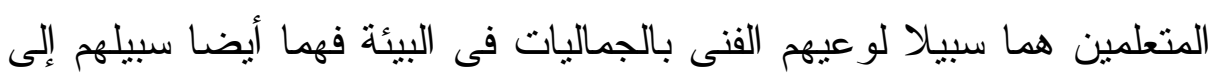

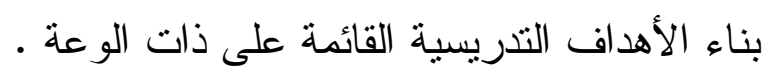

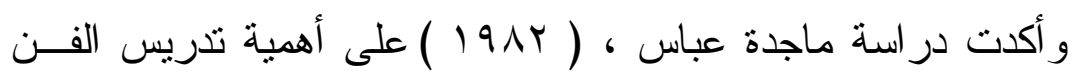

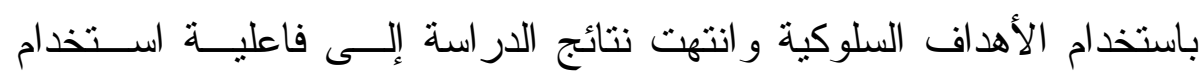
الأهداف السلوكية التي بنيت على ضوء تصنيف بلوم للأهداف في تــدريس

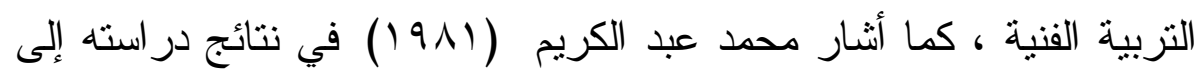

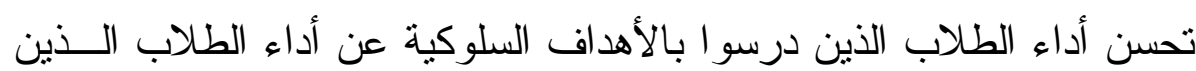

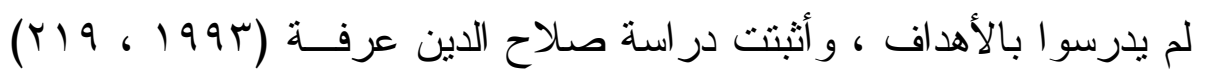

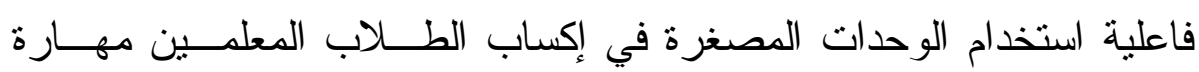

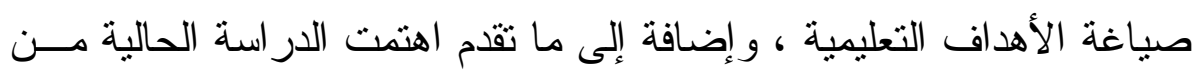

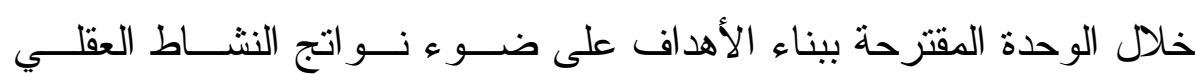

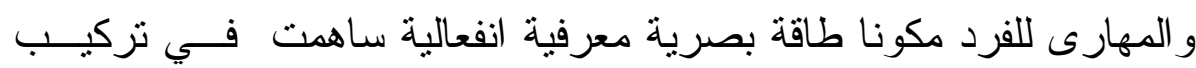

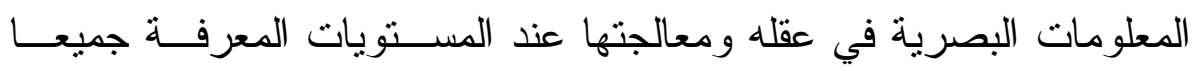

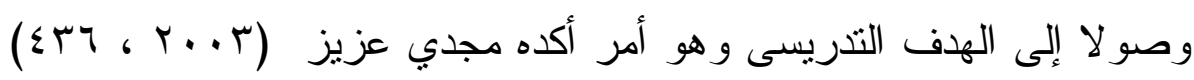
عند تعلم المفاهيم مما دعى الدراسة الحالية إلى الاهتمام بالمفاهيم الأساســية

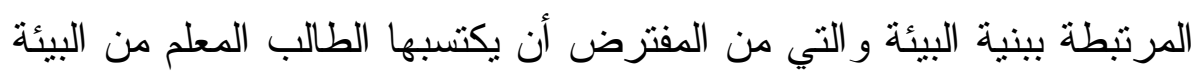

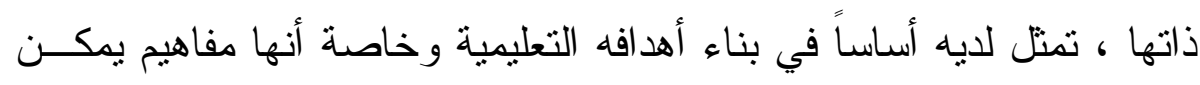
اسنقر ائها و استتباطها من البيئة المرئية المحسوسة المرتبطة بائه بالعناصر البنائية

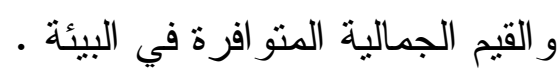

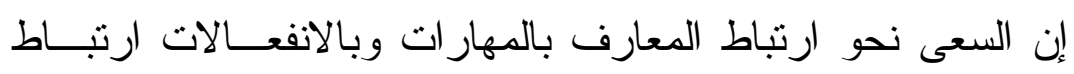

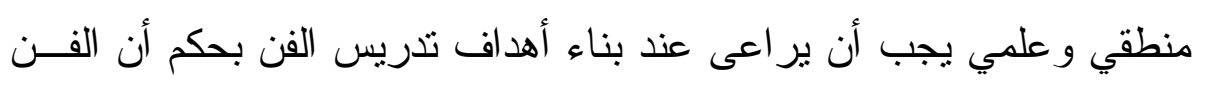


إدر الك حسى و عقلي و انفعالى بجماليات الو اقع البيئي ، وفى الارتبــاط بــين النشاط المعرفى للفرد بالبيئة .

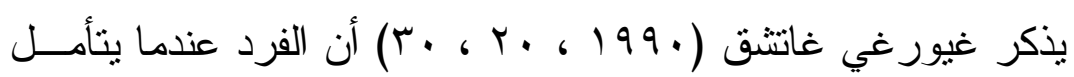

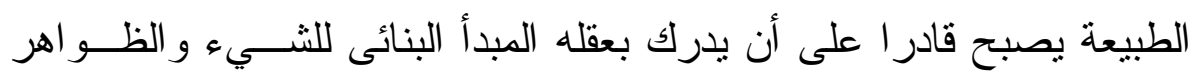

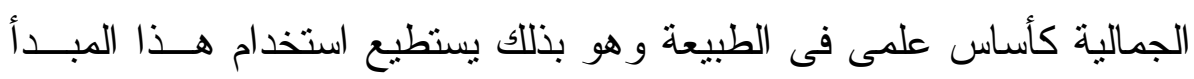

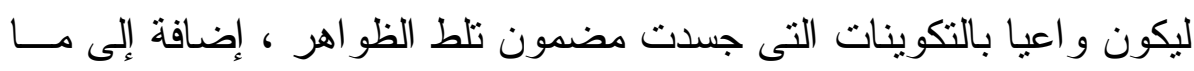

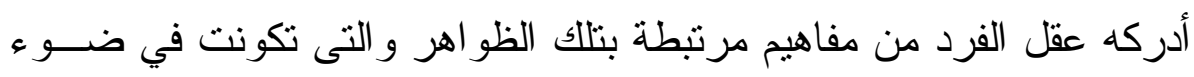

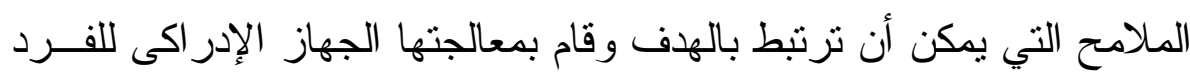

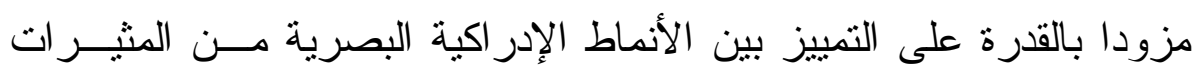
المرئية .

إن الطالب المعلم حينما يصف مكونات البيئة في موقف التعلم بنفســهـ

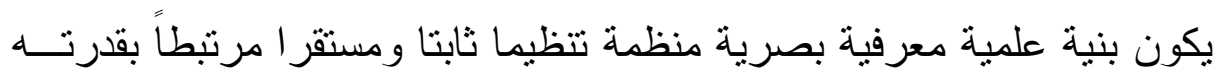

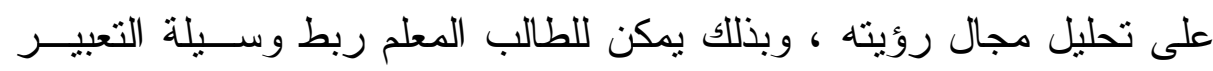

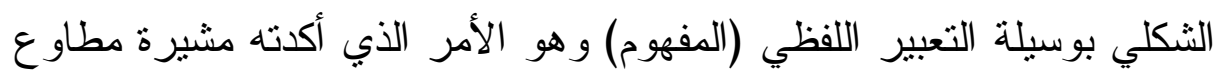

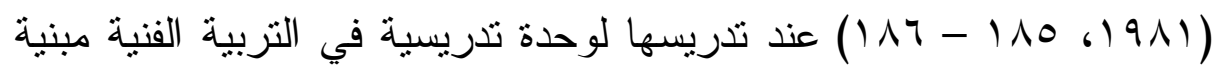

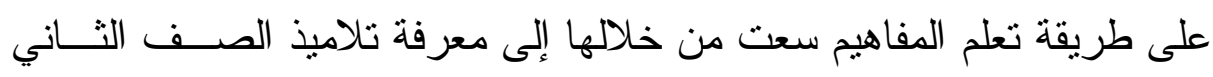

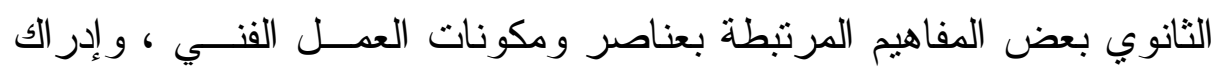

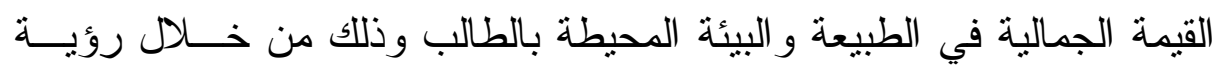

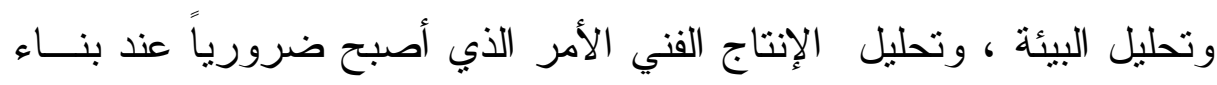

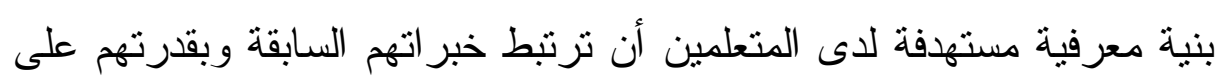
إيجاد علاقات بين ما سبق وما لحق من خبرة في الأمر ذات الأهمية بالأهداف 


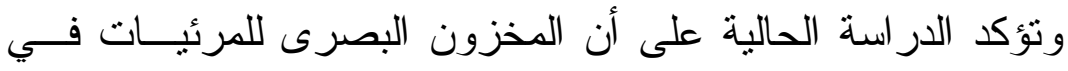

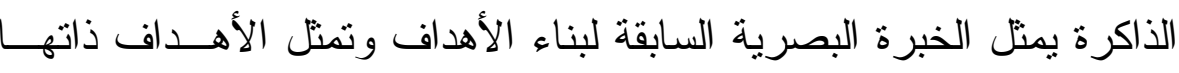

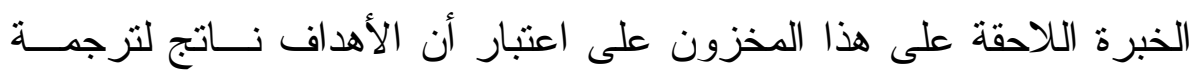

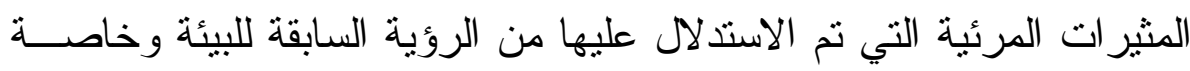

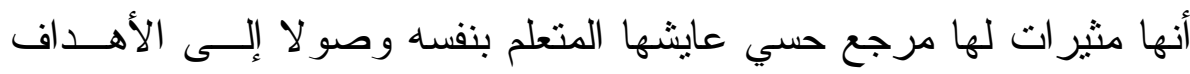

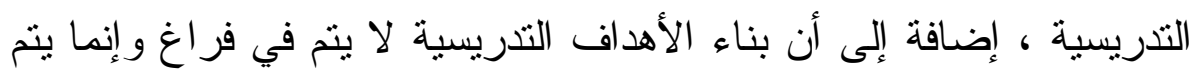

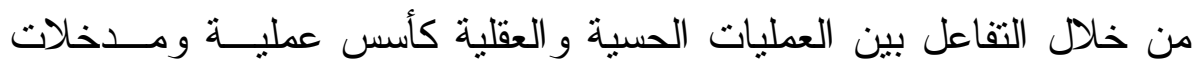
الرؤية البصرية وجميعها يمكن التدريب عليها فى مجال البيئة ذاتها ، الأمر

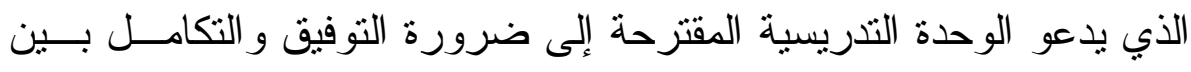
المطلوب الجديد وما سبق أن تعلمه المتعلم في المجال نفسه ، ومن ثم ثم أصبح

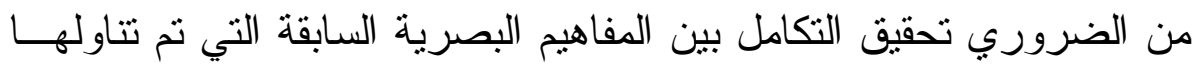

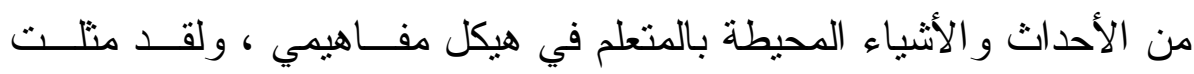

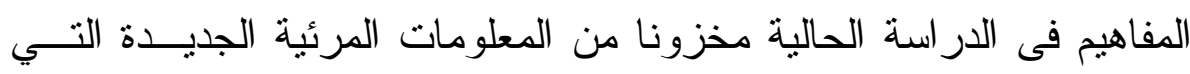

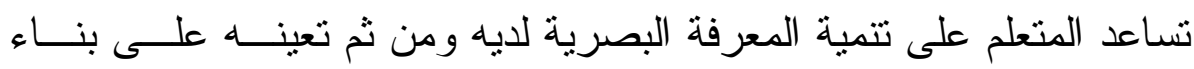

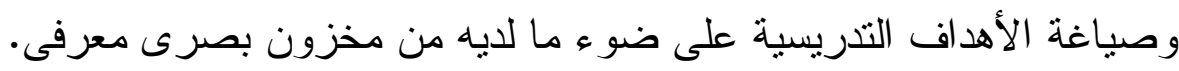

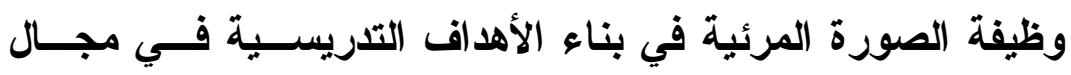

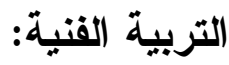

الصورة المرئية تحقق وظيفتها عندما تمثل مثير ا للتفكير المرئـى ،

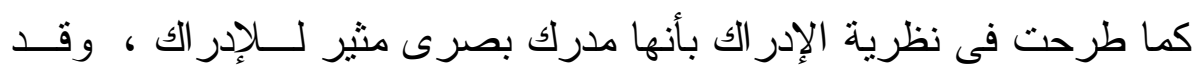

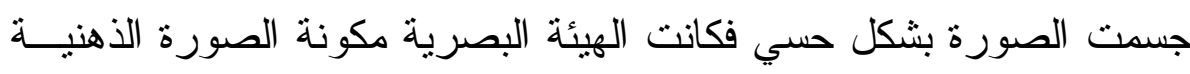

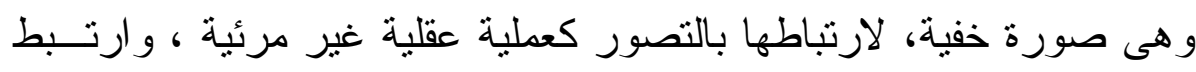

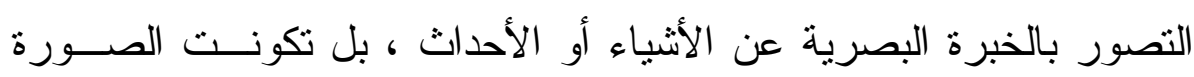


العقلية لدى الفرد عن شيء نتيجة تصور شيء آخر بالإضافة إلـى الخبــرة

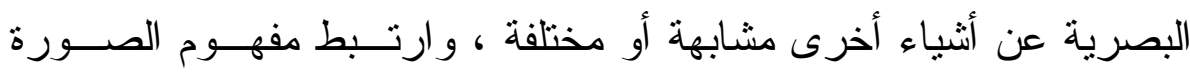

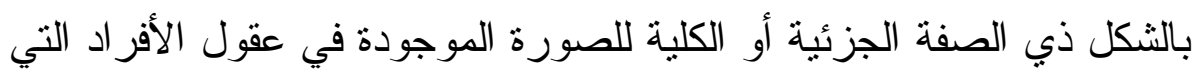

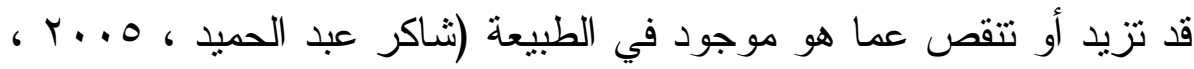
.$(1)$

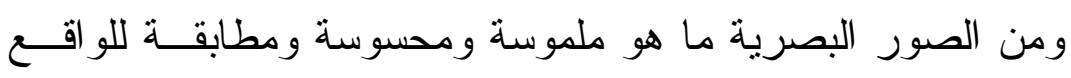

كصور العناصر أو الأثياء في البيئة ، ومنها الصورة النى تعبر عن الخبرة

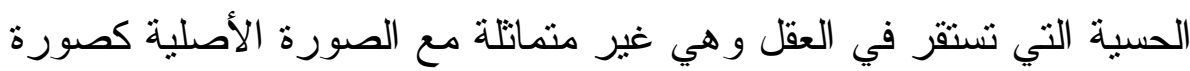

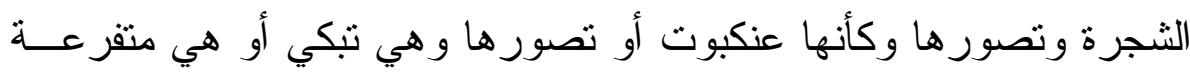

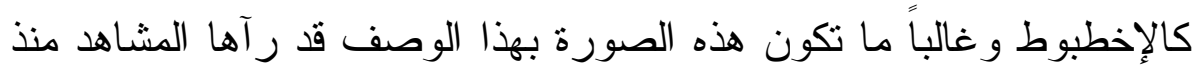

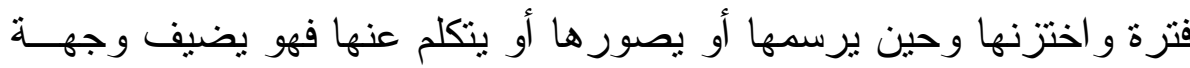

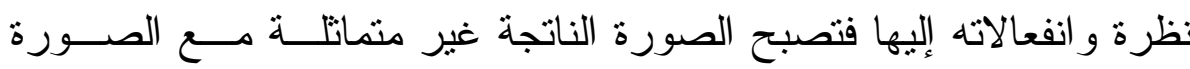
الأصلية فقد أعبد بنائها بصورة تعبيرية ، والصورة الذهنية من صفاتها أنها

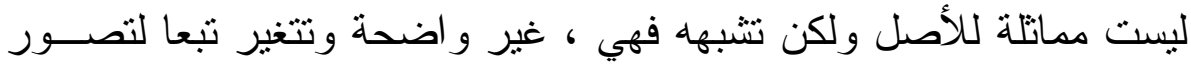

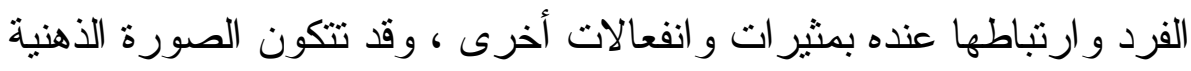

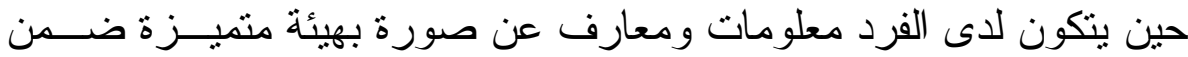
مجموعة هيئات أخرى فى نفس البيئة و الصور و الخيالية ناتجة مسن وجــود قدرة عقلية نشطة كونت تصور ات جديدة لتحوير وتركيب خبرات بصــرية

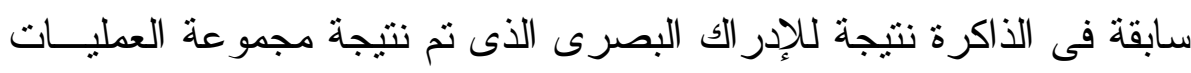

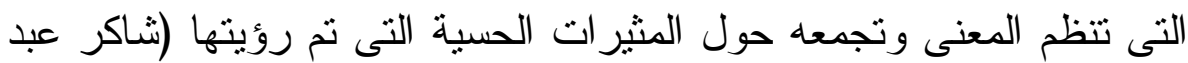

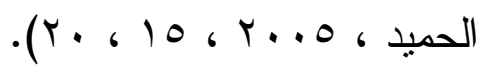


وتسعى الدر اسة الحالية من خلال دروس الوحدة التدريسية المقترحة

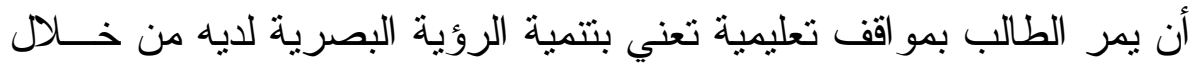

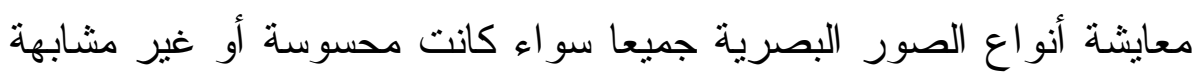

$$
\text { للأصل أو ذهنية أو متخيلة . }
$$

تكوين الصورة المرئية في البيئة وتكوين الأهداف التدريسية :

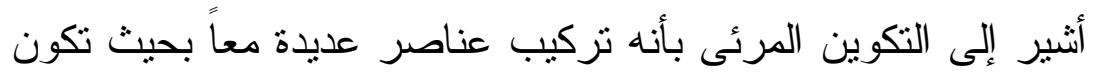

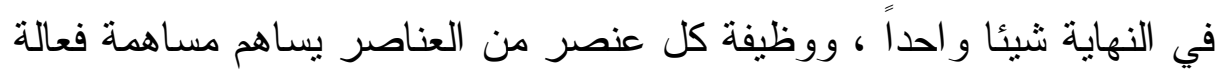

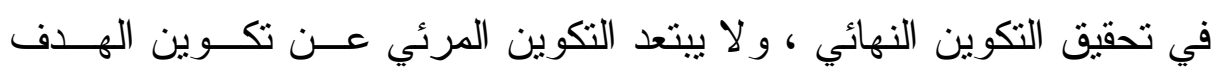

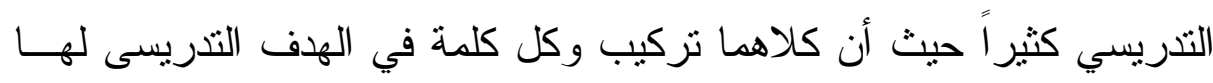

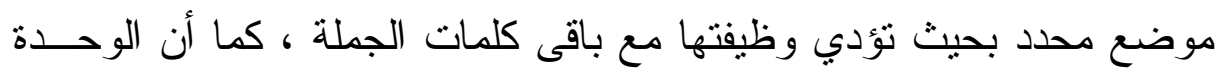

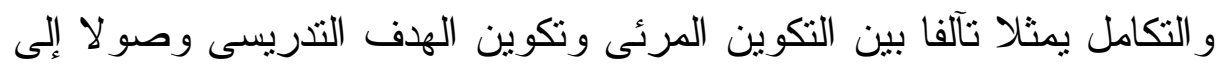

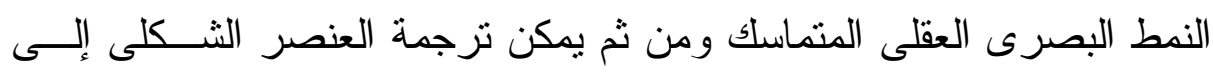

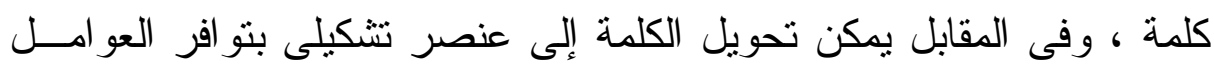

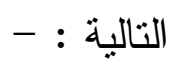

1.وجود عناصر شكلية عديدة في المشهد المرئى ، يقابلها كلمات في

$$
\text { الهدف }
$$

r.أن لكل عنصر شكلى وظيفة فى المشهد المرئى ، ولكل كلمة في

$$
\text { الهدف وظيفة. }
$$

r. أن لكل عنصر شكلى وضع ومقدار فى المشهد المرئى ، وكل كلمة فى

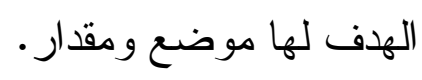

ع. أن لكل عنصر شكلى دلالة فى المشهد المرئى ، وكل كلمة في الهدف

$$
\text { لها وظيفة }
$$


0.كل عنصر فى المشهد المرئى له علاقة بالعناصر الأخرى وهي علاقة

تعكس تتظيما يتصف بالوحدة والإيقاع و التناسب و السيادة والاتزان كقيم جمالية بعكسها المشهد المرئى ، وكل كلمة في الهدف لها علاقة بالكلمات التي تسبقها أو تليها حتى تصبح جملة مفيدة وذات معنى مقصود . مقال

إن الهدف التذريسى أصبح بتلك الصورة نتــاج اســتجابات مرئيــة متثابهة ومختلفة نم تتظيمها فى فئات ذات معنى بعد عمليات تصنيفية عديدة

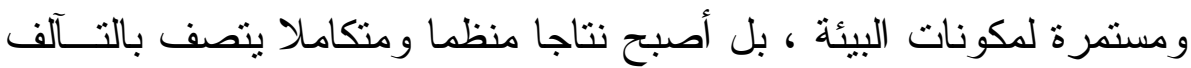

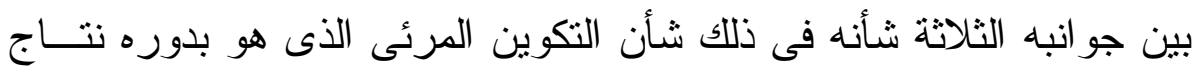

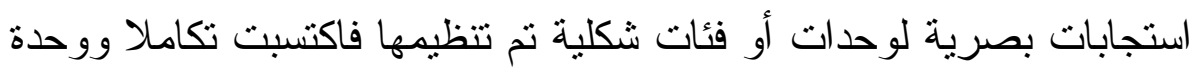
لنتابه خصائصها ووظيفتها مكونة نظام جمالى .

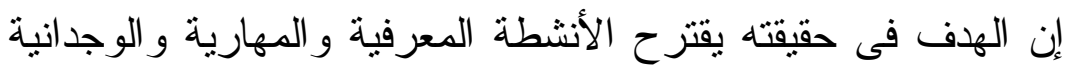

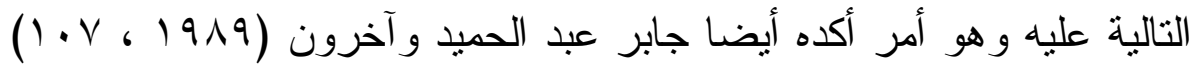

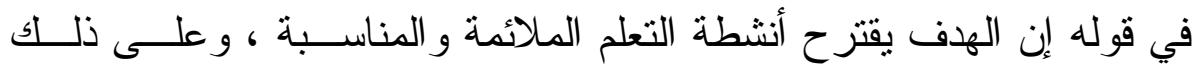

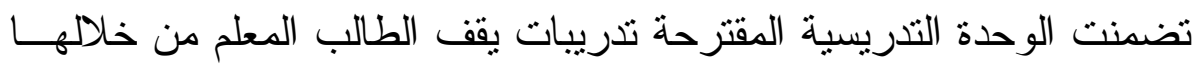

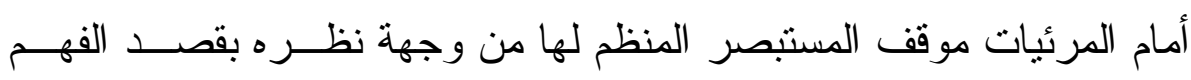

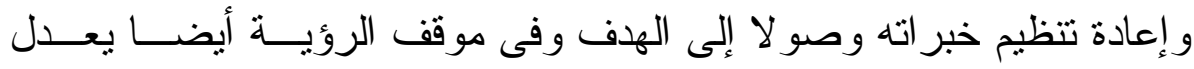

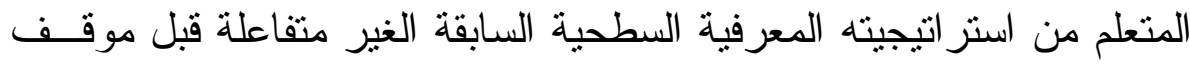
الرؤية إلى استر اتيجية تأملية تحليلية بصرية ليستدل من خلالها على مكونات التئه الأهداف التدريسية المرتبطة بتدريس الفن حيث ينتبه ويدرك وينتقي ويترجم

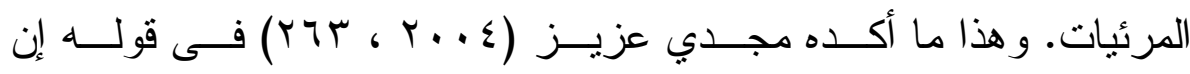
الاستر اتيجيات المعرفية ترتبط بالقدرة على البحث عن المعلومات و استيعابها 
فى الذاكرة بعد تفاعلها على أن تكون الملاحظة البصرية المستمرة هـي أداة

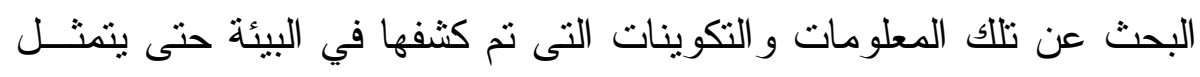

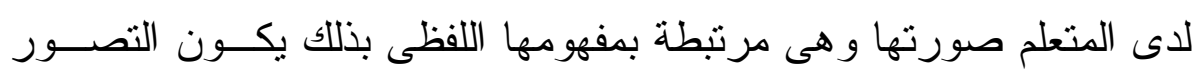
البصري له أثز فعال في فى تتمبة نشاط الذاكرة المعرفية وهو أمر أكده أنور

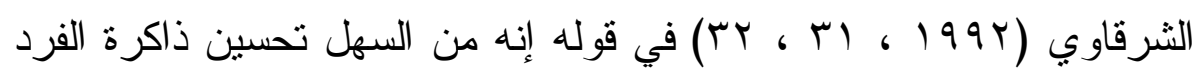
بو اسطة تدريبه على تكوين الصورة في ضوء استر اتيجية التصور التفاعلي

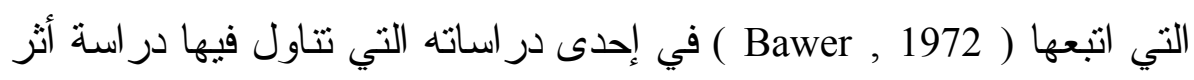

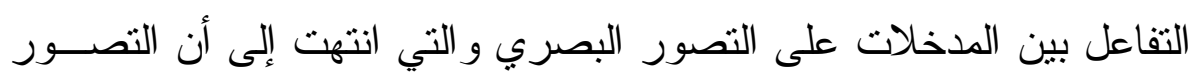

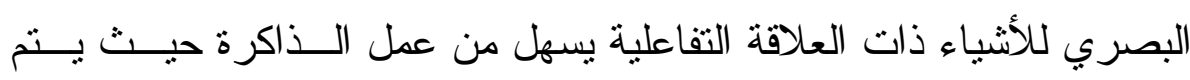

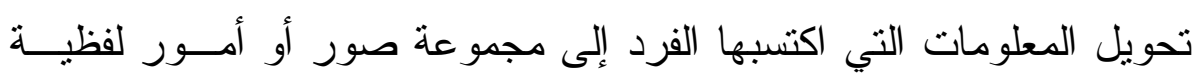

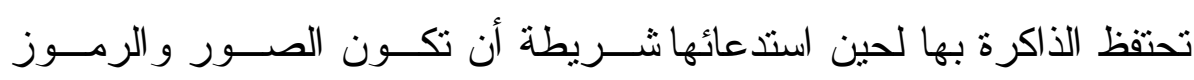

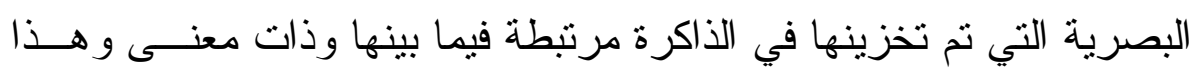

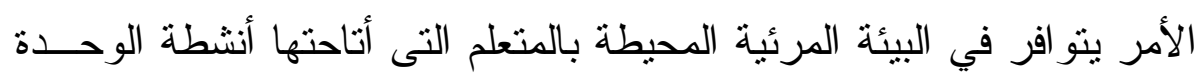

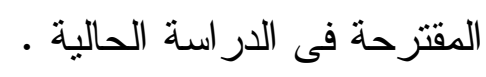

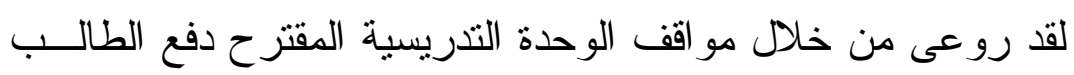
للمعايشة فى البيئة كمصدر للمعلومات المرئية لاستكثاف الخصائص البنائية

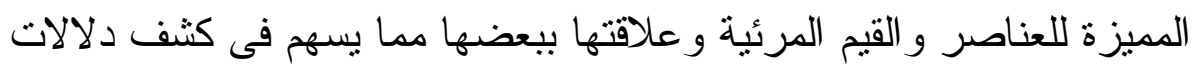

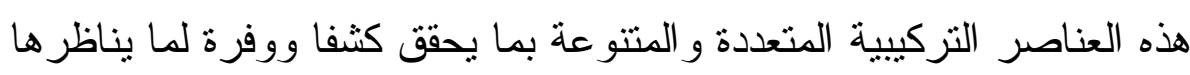

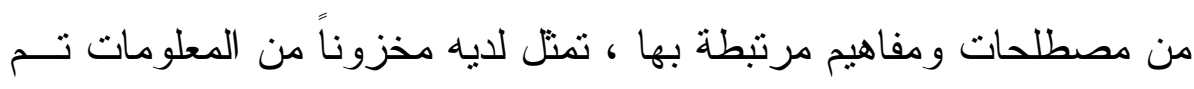

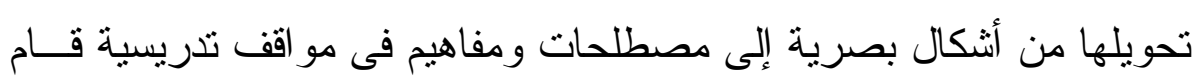

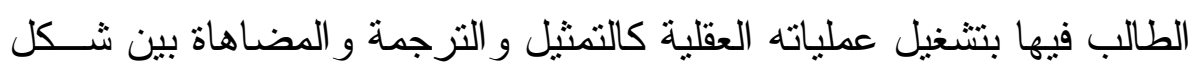
العنصر و المفهوم المرتبط به ، وهو أمر أثنار إليه , Cay Hullard , 1972 ) كمئل 
( 18 فى قولــه : من الضرورى تو افر الخبرات المرتبطة بالإدر الك البصرى

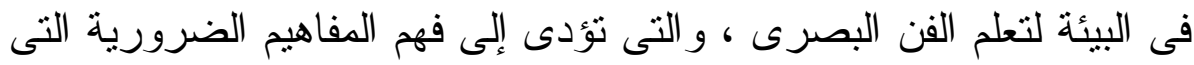

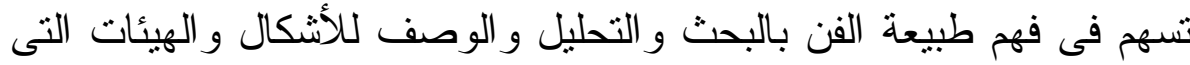

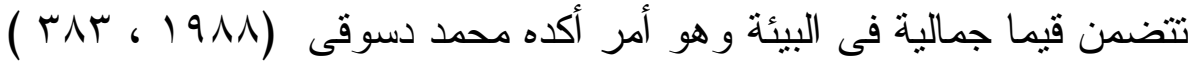
فى برنامجه التجريبى لممارسة التصوير فى قوله أن الطبيعة مصدر للمفاهيم

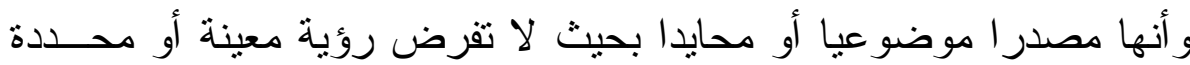
على الطالب ، بل أن الطالب نفسه هو الذى يتفاعل مع الثكل الطبيعى حيث يتبنى رؤية جمالية يدرك بها دلالات الطبيعة وظو اهرها، وهو أمر راعتـهـ الدر اسة الحالية فى المو اقف التدريبية التى تضمنتها الوحدة المقترحة ، حيث ينو افر أمام الطالب المعلم فرص وبدائل للرؤية لاكتشاف التكوينات الثــــلية فى البيئة بنفسه ثم دلالاتها الجمالية ومن ثم مر ادفاتها اللفظية مما يدعم حريته

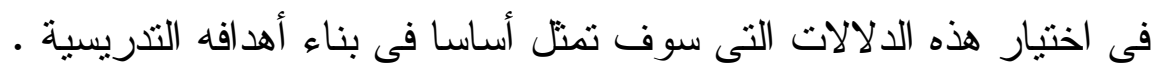
كما روعى عند تدريس الوحدة المقترحة دفع المتعلمين وتــوجيهمج

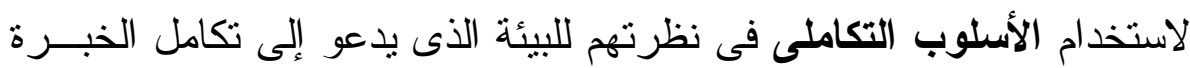

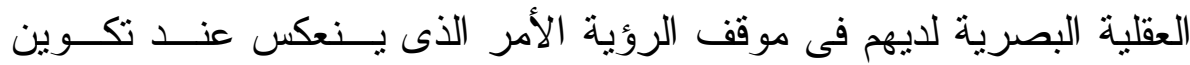

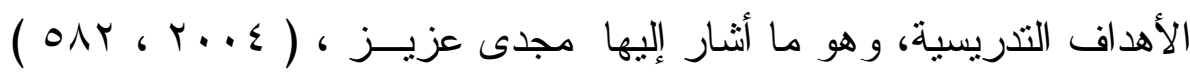

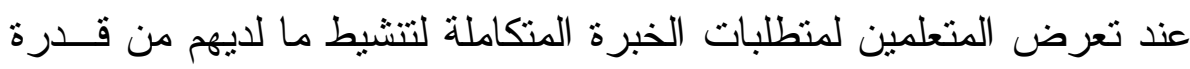
عقلية على إيجاد العلاقات الرمزية المجردة بين الأثكال ومن ثم بين المفاهيم

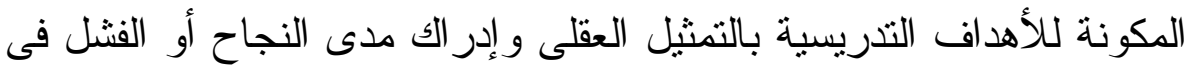
ذلك .

وقد روعى أيضا ضمن الوحدة التدريسية المقترحة بنـــاء المعرفـــة البصرية فى عقل المتعلم بواسطة المتعلم ذاته وهو ما تؤكده النظرية البنائية 


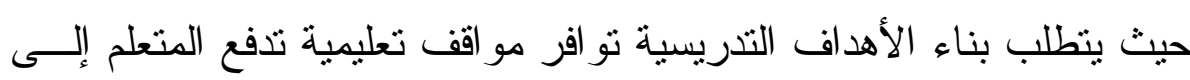

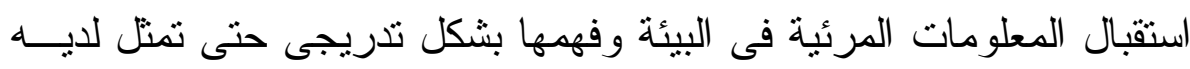

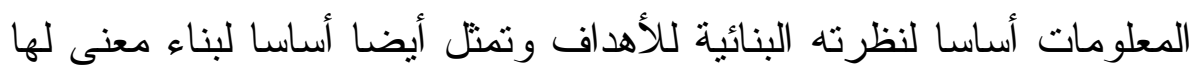

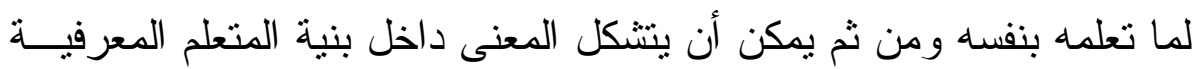
بناء على رؤيته الخاصة.

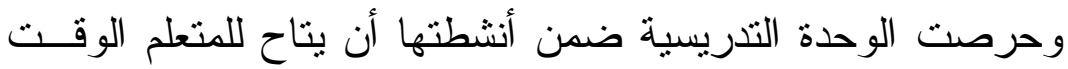

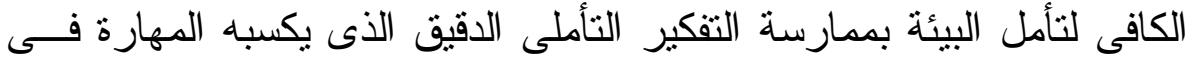

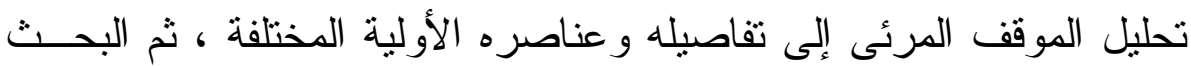

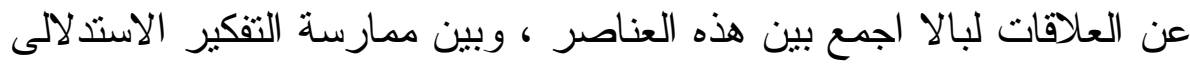
التى تمكنه من الكثف عن العديد من المرئيات وما بينها من علاقات منتشابكة

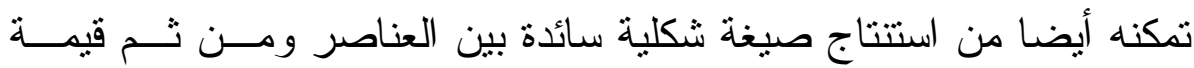
تتظيمية جمالبا كالإيقاع و الوحدة و الإتز ان ، و السيادة . إن من العظماء و الدفكرين من اعتمد على التفكير البصرى أكثر من

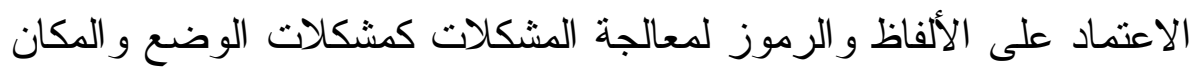

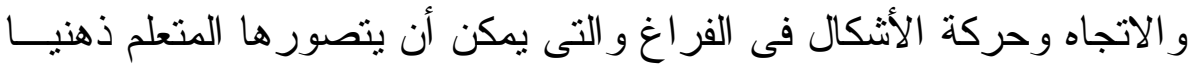
ثم يترجمها عمليا بصورة منضبطة فى سياقات و اقعية متكاملة ذات قيمة . و استمر ار الدفع المتعلمين للتفكير المعرفى البصرى تضمنت الوحدة

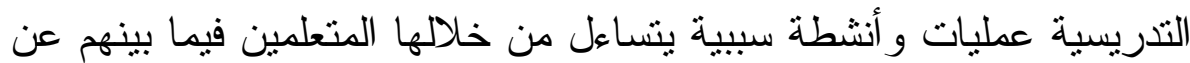

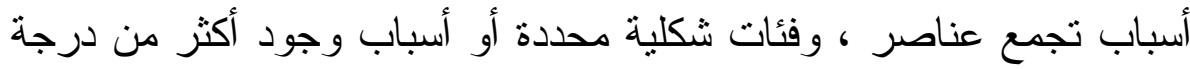
للون الواحد فى العنصر الواحد فى البيئة ، وكذلك أنثطة مرتبطة بممارسات

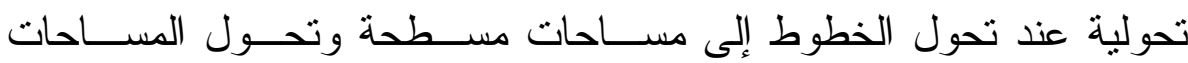
المسطحة إلى أثنكال ثلاثية الأبعاد ( مجسمة ) ، وتحولى الحول الإيقاع المنتظم بين 
الأثكال إلى إيقاع غير منتظم بسبب تحرك تلك العناصر فى الفر اغ ، وتغيير

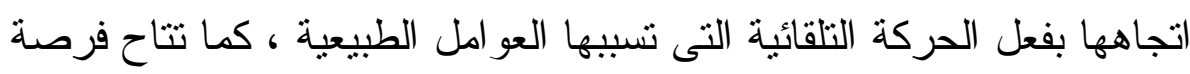

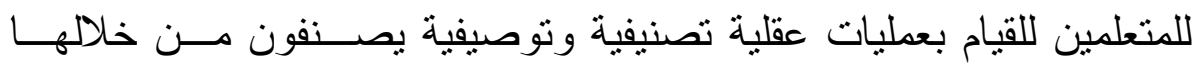
الخطوط و الأنثكال المسطحة الأفقية و الر أسية و المائلة و المنكسرة و المنحنيــة

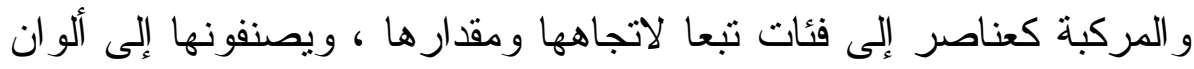

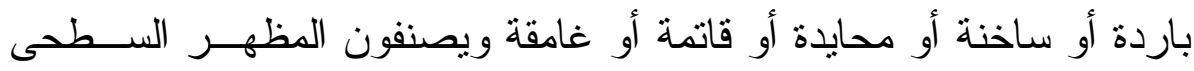

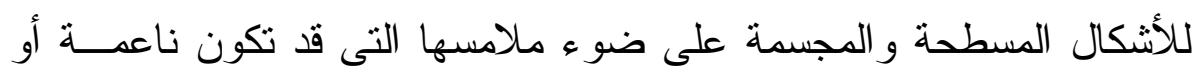

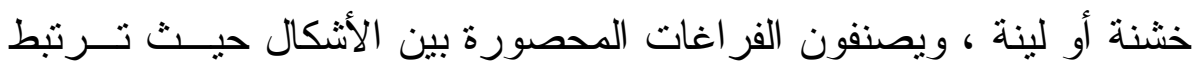

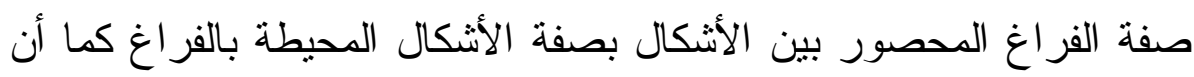

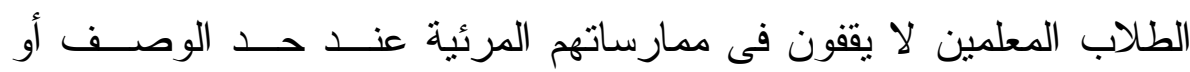

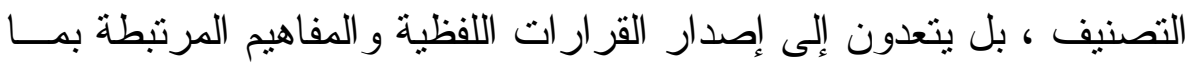
رأوه ووصفوه شكلبا ، وهم فى ذللك يوظفون رؤياهم تبعا لحاجاتهم لكفــاهيم

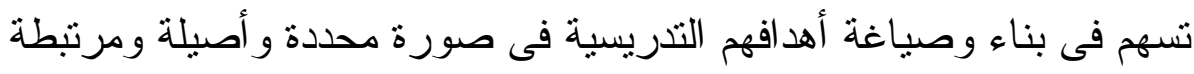

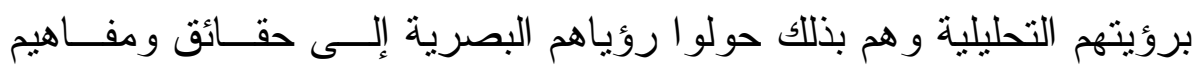
بطرق علمية ومنظمة وصو لا إلى أهداف ممكنة ومر غوبة .

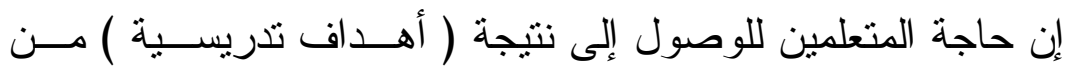

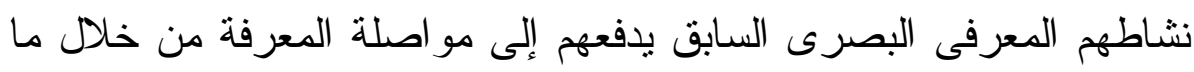
: يلى :

أ- البحث عن المعلومات البصرية المكونة للأهداف . ب- تمثيل المعلومات بنظام رمزى شكلى • ج- تحويل المعلومات من رموز بصرية إلى رمــوز لفظيــة (حقــائق

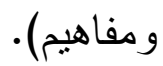


د-تتظيم الحقائق و الدفاهيم تتظيما وظيفيا .

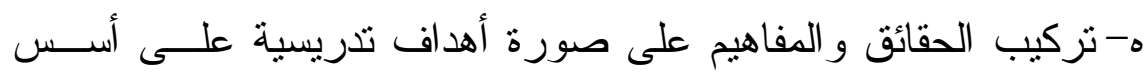

علمية

$$
\text { و - - إعادة نركيب الأهداف التدريسية بصورة إجر ائية سلوكية. }
$$

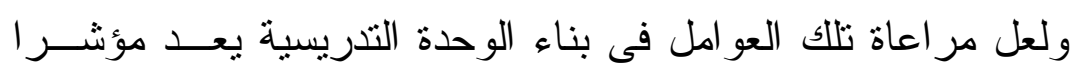

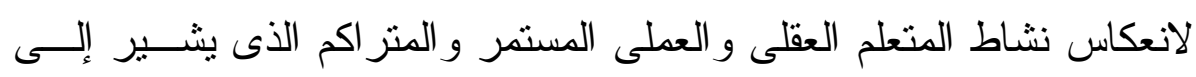

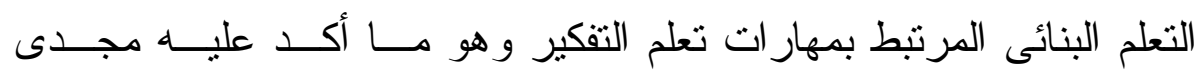

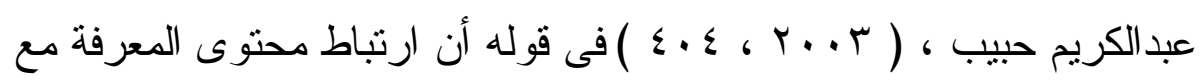

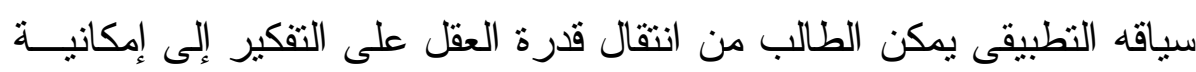

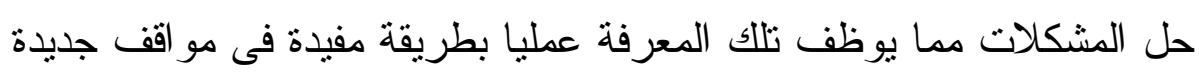

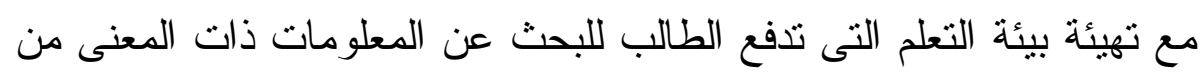

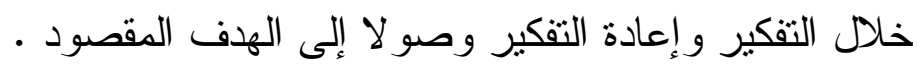

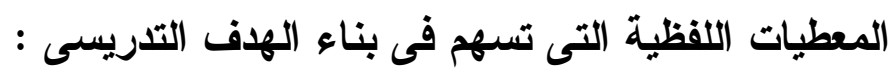

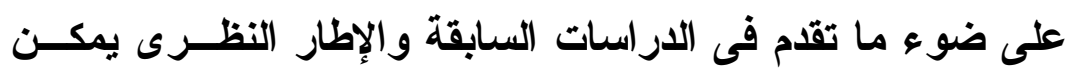
تصور المعطيات اللفظية التى تسهم فى بناء الهذف التدريسـى في بالصــورة التالية : 


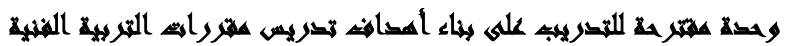

جدول (1)

\begin{tabular}{|c|c|c|c|c|c|c|}
\hline v مكون v & مكون 7 & \multirow{2}{*}{ مكون • } & مكون ؛ & \multirow{2}{*}{ مكون r } & \multirow{2}{*}{ مكون r r } & مكون 1 \\
\hline مقرارات التربية الفنية & القيم الجمالية & & الصناصرة البصرية & & & الأسس \\
\hline أ. أنشغال معادن & أ. الإيقاع & تتصف ب & أ. نقط & من & أ. صياغات & أ. تذكر \\
\hline ب. أثشغال خشب & ب. الوحدة & تنضمن & ب. خطوط & بين & ب. تشكيلات & ب. معرفة \\
\hline ج. النصميم & ج. النتاسب & & ج. مساحات & فى & ج. تكوينات & ج. تطبيق \\
\hline د. الرسم & د. السيادة & & د. أجسام & & د. تعبير ات & د. تحليل \\
\hline هـ. التصوير & هـ الاتز ان & & هـ. ألو ان & & ه. أعمال فنية & ه. تركيب \\
\hline و. النسيج & & & ז. فر اغات & & & \\
\hline ز • الطباعة & & & V. ملامس & & & \\
\hline ح. أثنغال فنية & & & & & & \\
\hline ط. تاريخ فني & & & & & & \\
\hline ى. تذوق & & & & & & \\
\hline ك. النحت & & & & & & \\
\hline ل. الخزف & & & & & & \\
\hline
\end{tabular}

أمثلة على الوحدة التدريسية على ضوء المعطيات السابقة :

- الهوف:تذكر تشكيلات من النقط تتصف بالإيقاع فى الششغولة المعدنية

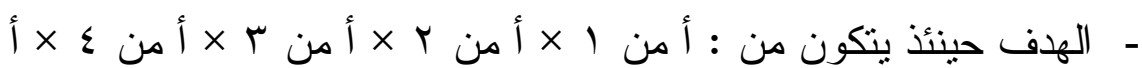

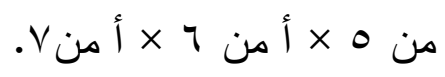

- الهدف : معرفة صياغات من المساحات تتصف بالتتاسب .

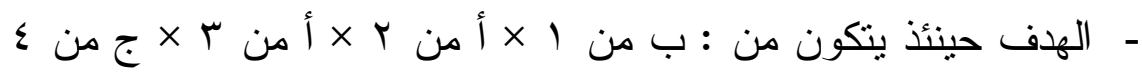

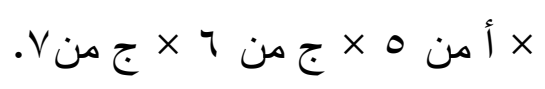

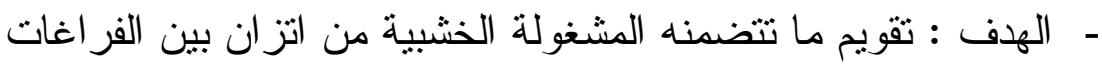

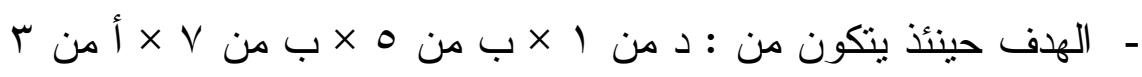

$$
\text { . } 1 \text { ه } 1 \text {. }
$$


- الهدف : تحليل أجسام من النحت تتضمن إيقاعا فى الملمس .

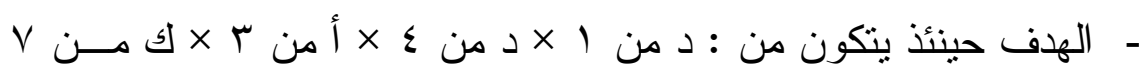

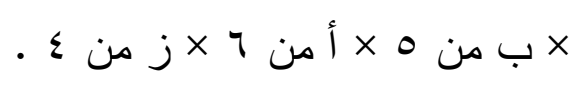

- الهلف : تركيب تكوينات فى التصوير تنصف من عالاتز ان اللونى.

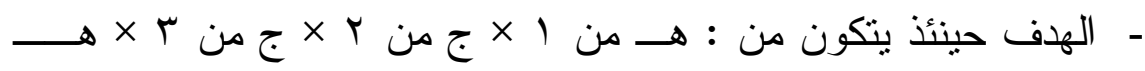

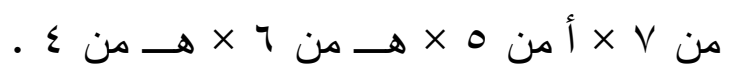

- الهدف : نركيب تكوينات فى التصوير تتصف بالتتاسب الخطى .

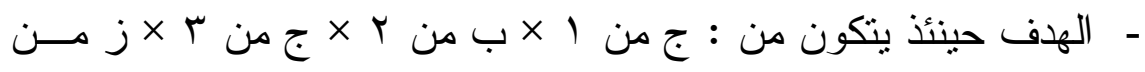

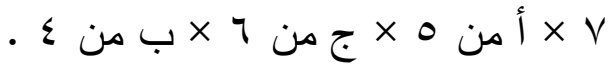

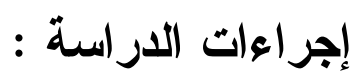

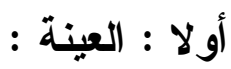

طبقت المعالجة التجريبية على عينة من طلاب الفرقة الثالثة تربيـــة

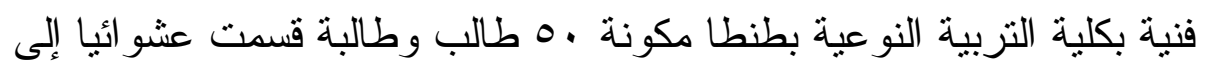
مجمو عة تجريبية وضابطة وتدرس المجموعة التجريبية الوحدة المقترحة .

$$
\text { تجانس العينة : }
$$

تحدد مدى تجانس المجموعتين التجريبية والضابطة في المتغيرات التابعة باستخدام اختبار (ت) للقيم غير المرتبطة في درجات القياس القبلي

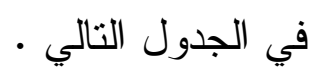




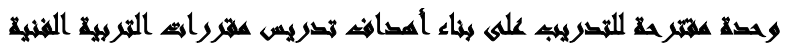

\section{جدول (r) جان (r)}

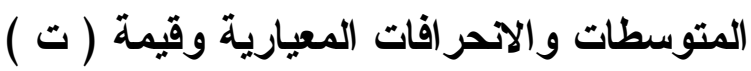

ومستوى دلالتها فى اختبار تحليل البيئة للمجموعتين

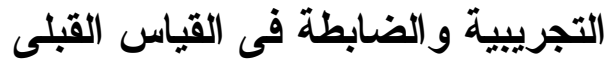

\begin{tabular}{|c|c|c|c|c|c|}
\hline مستوى الدلاية & $ت$ & $\varepsilon$ & P & ن ن & المجموعاتة القياسات \\
\hline \multirow{2}{*}{ غير دال } & & $\varepsilon, O r$ & $r \checkmark, \wedge \wedge$ & ro & تج • ق \\
\hline & & $\varepsilon, \varepsilon \varepsilon$ & $r ד, 9 T$ & ro & ص. ق \\
\hline
\end{tabular}

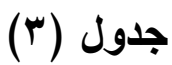

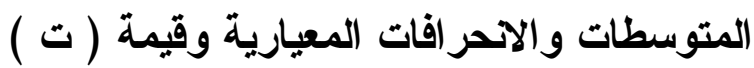

ومستوى دلالتها فى اختبار بناء الأهداف على ضوء الأسئس العلمية

ونو اتج تحليل البيئة للمجموعتين التجريبية والضابطة فى القياس القبلى التئي

\begin{tabular}{|c|c|c|c|c|c|}
\hline مستوى & ت & $\varepsilon$ & p & $\dot{ن}$ & مجموعات القياسات \\
\hline \multirow{2}{*}{ غير دال } & & $1 \cdot, r 9$ & $19 \pi, Y \wedge$ & ro & ج. ق \\
\hline & & $I Y, Y V$ & 109,17 & ro & ט. ق \\
\hline
\end{tabular}

يتضح من الجدولين السابقين تجانس المجموعتين في درجات القياس

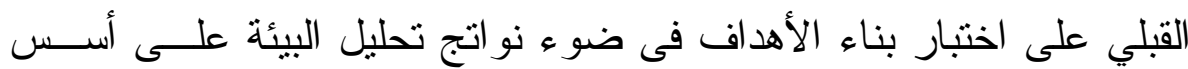
العلمية مما يدل على عدم وجود فروق فعلية بينهما الأمر الذى يعنى تجانس المجمو عتن قبل إجر اء المعالجة التجريبية : ثانيا : الأدوات :

1.اختبار تحليل البيئة - إعداد الباحث . 


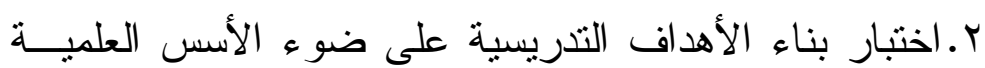

ونو اتج تحليل البيئة - إعداد الباحث ـ الاهن

$$
\text { إجراءات بناء الاختبار : اختبل : البيئة : }
$$

أ- الهذف من الاختبار : الوقوف على ما تتضمنه البيائـة مـنـ

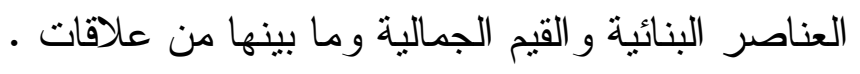

ب- محتوى الاختبار : قام الباحث بحصر الدراسات و البحوث التي

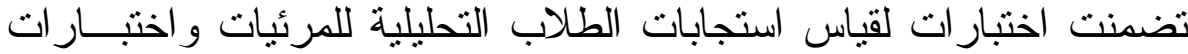
تحليل الأعمال الفنية ، وتحليل محتوى محور الرؤية الفنية في مناهج التربية

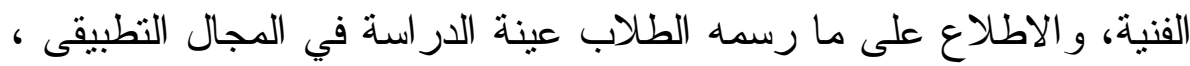
وكذا تحليل محتوى الوحدة التدريسية المقترحة وتحليل مشاهد متعـددة فــي

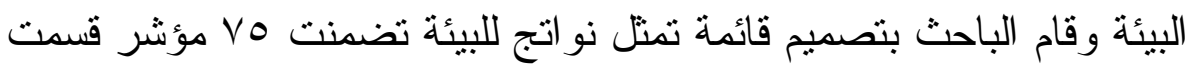

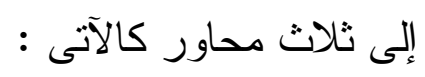

- المحور الأول : ويتضمن العناصر البنائية والتــي تســهم فــي بنــاء

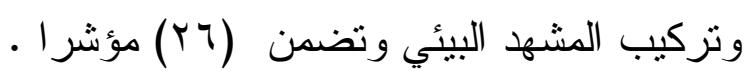

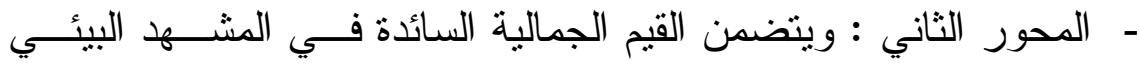

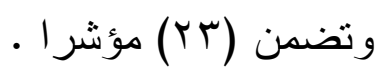

- المحور الثالث : وتضمن العلاقات بين العناصر البنائية و القيم الجمالية

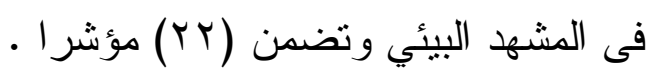

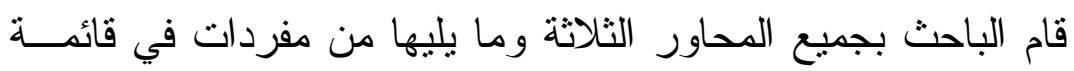

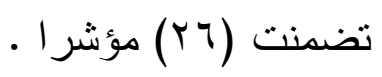




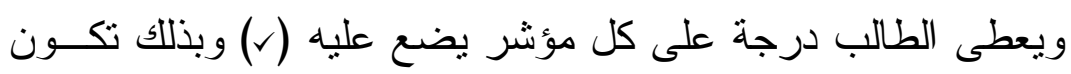

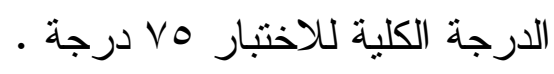

ج- التجربة الاستطلاعية للاختبار :

\section{الهدف من التجربة :}

- - التأكد من صلاحية الاختبار للنطبيق : -

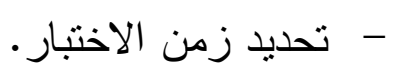

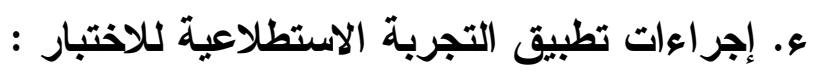

قام الباحث بتوزيع الاختبار على 10 طالباً وطالبة .

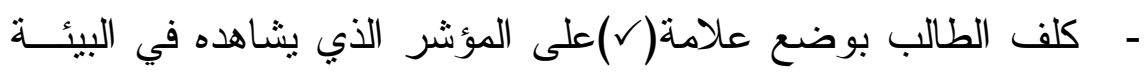

$$
\text { المحيطة به }
$$

- تم تصحيح الاختبار بوضع درجة واحدة لكل مؤشر بصــري وضــع

$$
\text { عليه الطالب (،). }
$$

هـ - تحليل نتائج التجربة الاستطلاعية للاختبار :

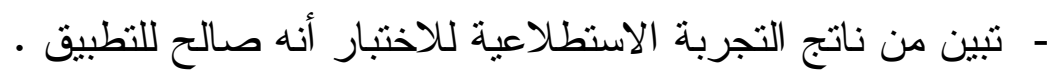

و - تحدد زمن الاختبار بالمعادلة التالية :

تم تحديد زمن الاختبار بتطبيق المعادلة التالية :

$$
\text { مج الدقائق التي استغرقها الطلاب }
$$

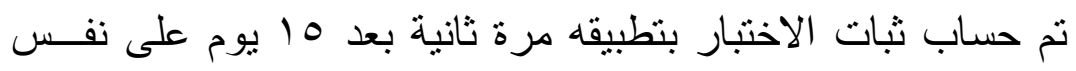

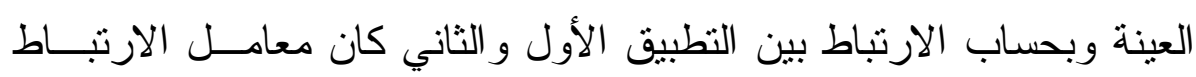

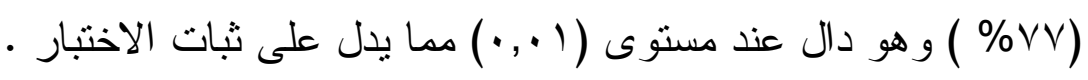




\section{ح- صدق الاختبار :}

تم عرض الاختبار ومرفق به الوحدة التدريسية على لجنة المحكمين

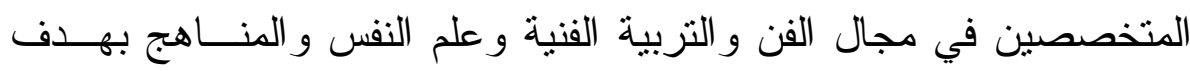

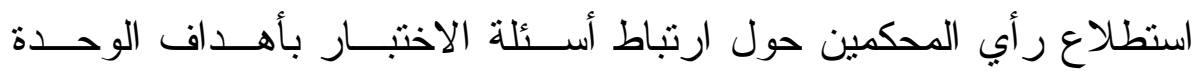
التدريسية ور أي المحكمين أن الاختبار صادقا إلى حد كبير بنسبة ( •^ \% \%).

وبذللك أصبح الاختبار فى صورته النهائية ملحق رقم ( ) r. اختبار بناء الأهداف التدريسية :

أ- الهلف من الاختبار : قياس قدرة طلاب النزبية الفنية على بنــاء الأهداف التنريسية على ضوء نواتج تحليل البيئة من العناصر البنائية و القيم

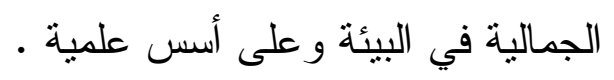

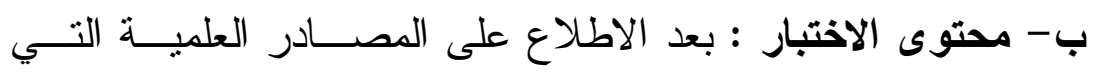

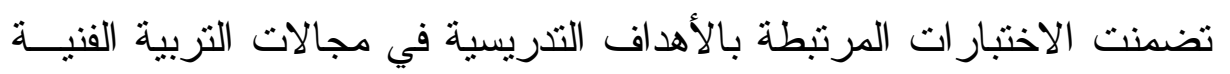

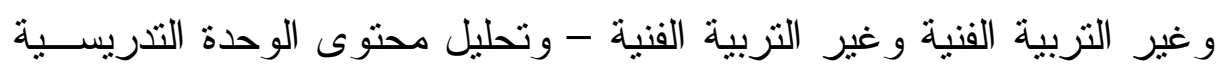

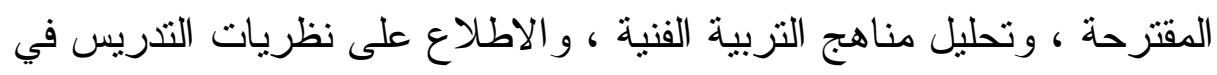

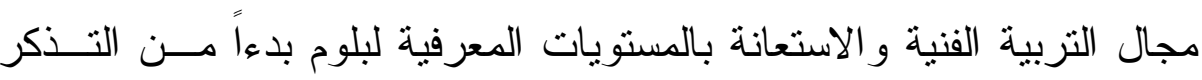
لالتقويم مجن

\section{احتوى الاختبار على محورين :}

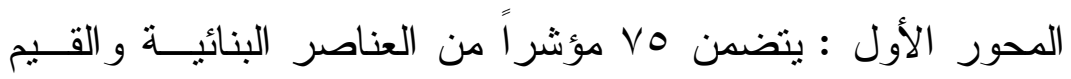

الجمالية و العلاقات و التى منلت نو اتج تحليل البيئة . ل

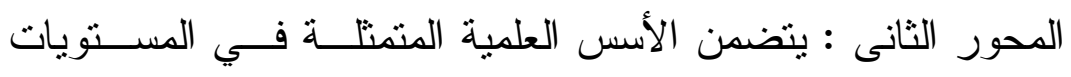
المعرفية لبلوم ( المعرفة - الفهم - التطبيق - التحليل - التركيب - التقويم). 
للطالب الحرية فى اختيار المقررات الفنية التى يمكن أن يصيخ فيها

أهدافه التدريسية و التى تحددت بـ (Y () مجال وبذلك يكون مجمل عبار ات الاختبار حاصل ضرب المستويات المعرفية الست × عدد المؤشرات (نواتج

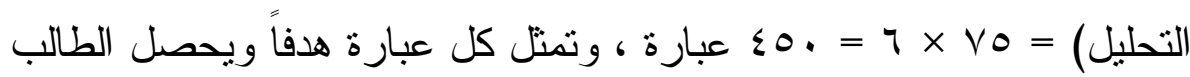

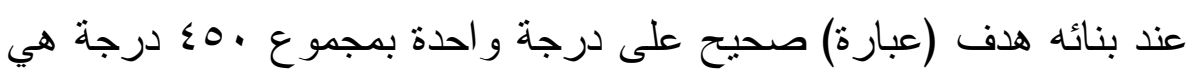

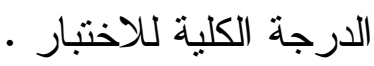

ج- التجربة الاستطلاعية للاختبار : الهاف من التجربة :

1. التأكد من صلاحية الاختبار للتطبيق .

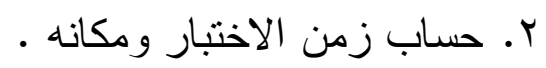

ع- إجراءات تطبيق التجربة الاستطلاعية للاختبار :

قام الباحث بتطبيق الاختبار 10 طالباً وطالبة . هـ - نتائج التجربة الاستطلاعية : أثنتت نتائج التجربة الاستطلاعية قدرة الطلاب على صياغة الانطة الأهداف كما أمكن تحديد زمن الاختبار بالصورة التالية : و الذي بلغ · و دقيقة تقريبا

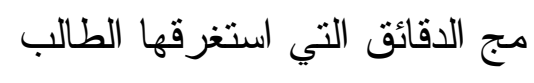

$$
\text { عدد الطلاب }
$$

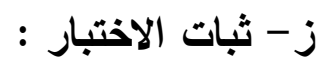

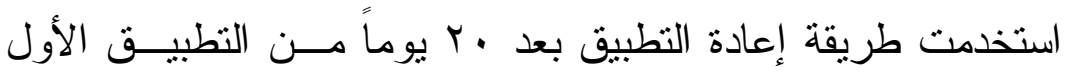

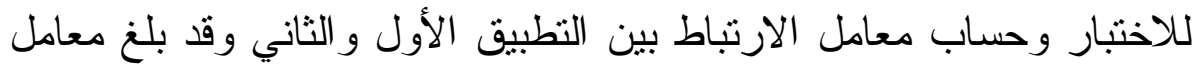

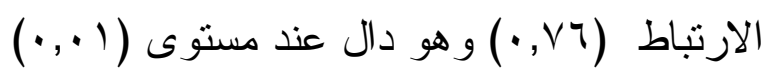




\section{ح- صدق الاختبار :}

قام الباحث باستطلاع ر أي المحكمين المتخصصين حول مدى ارتباط

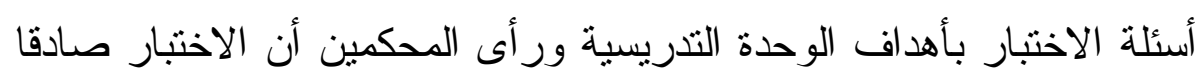

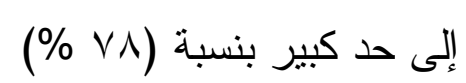

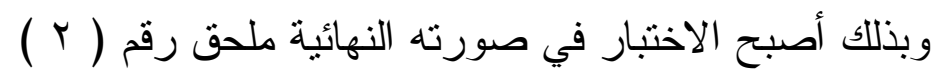
ثالثا : الوحدة التدريسية

\section{ا ـ الهدف من تدريس الوحدة :}

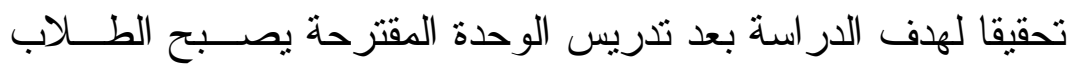

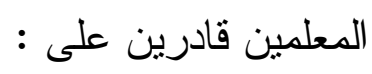

صياغة وبناء الأهداف التدريسية في مجال التربية الفنية على ضوء

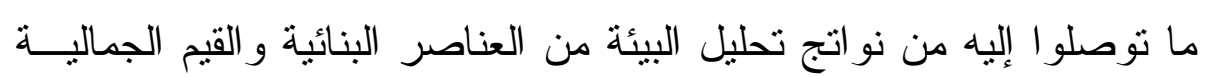

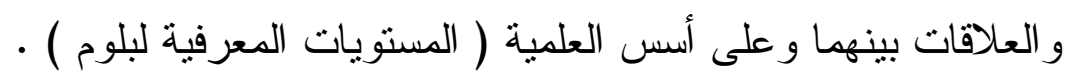
ويتضمن الهدف السابق الجوانب التالية : أ- بالجوانب المعرفية للهرف :

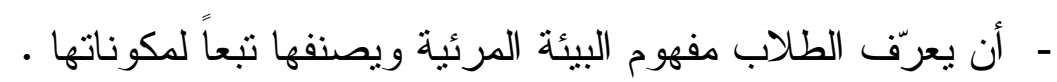
- - أن يتعرف الطلاب على العناصر البنائية المكونة للبيئة في مشهد مرئي. - أن يتعرف الطلاب على القيم الجمالية في البيئة في مشهد مرئي من البيئة

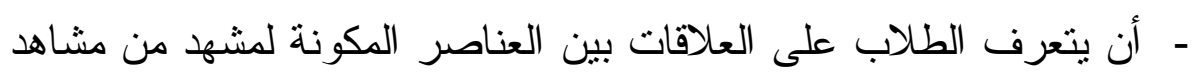

البيئة

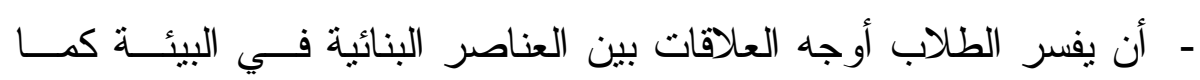
شاهدها - أن يذكر الطلاب العلاقات بين القيم الجمالية في البيئة كما شاهدها. 
- أن يعرف الطلاب الأسس العلمية لبناء الأهداف التذريسية فــي التزبيــة الفنية

- أن يعرف الطالب العلاقة بين البيئة ومناهج النربية الفنية .

- أن يعرف الطلاب الجو انب المرتبطة بالهدف التدريسى عند صياغته.

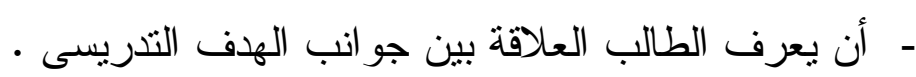

- أن يفسر الطلاب العلاقة بين الأسس العلمية و الأهداف التنريسية .

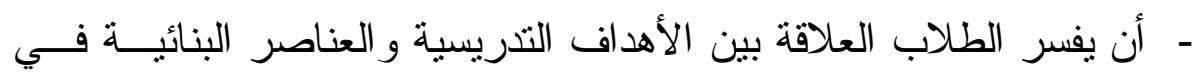
البيئة

- أن يفسر الطلاب العلاقة بين الأهداف التدريسية والقيم الجمالية في البيئة

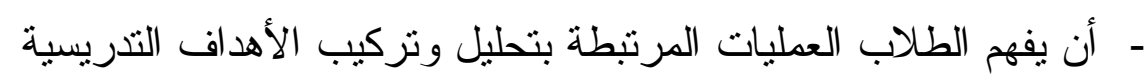
- أن يتعرف الطلاب على نماذج من التراث الفني البصري .

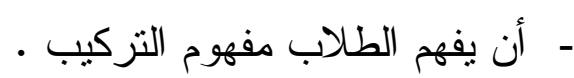
- أن يعرف الطلاب مفهوم إعداد الدروس في مجال التربية الفنية .

$$
\begin{aligned}
& \text { - أن يعرف الطلاب الأهداف التدريسية . } \\
& \text { - - أن يعرف الطلاب مفهوم التقويم - } \\
& \text { - أن يقوّم الطلاب دروس التربية الفنية . } \\
& \text { ب- الجواتب المهارية للهرف : }
\end{aligned}
$$

- أن يترجم الطلاب المصطلحات و المفاهيم المرتبطة بالعناصــر البنائيــة و القيم الجمالية وما بينها من علاقات إلى رسوم وتخطيطات. - أن يحلل الطلاب مشاهد من البيئة .

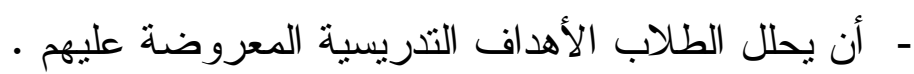


- ـ أن يحلل الطلاب الرسوم و الصور المرتبطة بالبيئة في منــاهج التربيـــة الفنية .

- أن يحلل الطلاب القيم الجمالية في البيئة .

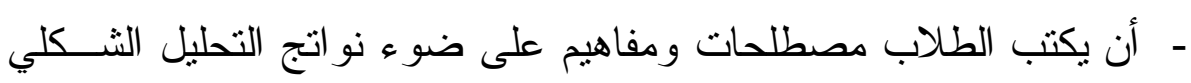
للبيئة - أن يركب الطلاب من المصطلحات و المفاهيم الناتجة من التحليل أهـــاف تدريسية

- أن يركب الطلاب أهدافا تدريسية تضمن أسس علمية (مستويات معرفية)

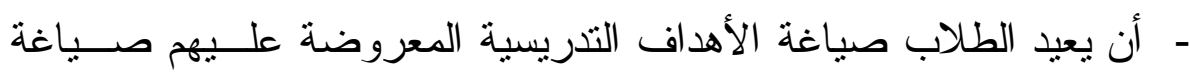

\section{صحيحة}

- أن يركب الطلاب أهداف ندريسية تتضمن عناصر شكلية في البيئة . - أن يركب الطلاب أهداف تدريسية تتضمن قيم جمالية في البيئة . - أن بركب الطلاب أهداف تدريسية تتضمن قيم جمالية و عناصر بنائية - أن يركب الطلاب الأهداف التدريسية من مفاهيم في مجالات التربية الفنية

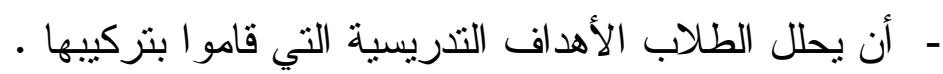

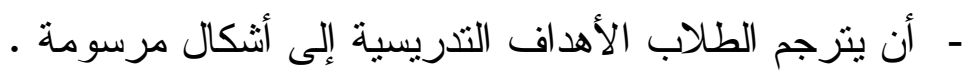
- أن يترجم الطلاب الأثكال المرسومة إلى أهداف تدريسية .

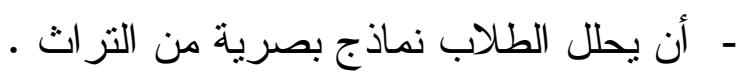
- - أن بترجم الطلاب النماذج البصرية إلى مصطلحات ومفاهيم لفظية .

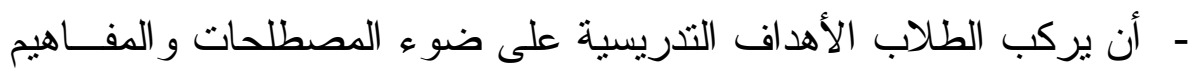
اللفظبة 
- أن يصيخ الطلاب أهدافاً تدريسية في مجالات التزبية الفنية المختلفة .

- أن يكتب الطلاب إجر اءات الدرس المنزتبة على الهذف التدريسي .

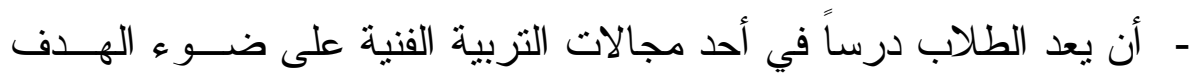

$$
\text { التدريسي }
$$

-

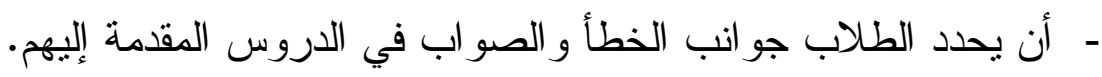
- أن يعيد الطلاب إعداد الدروس بصورة صحيحة ل

\section{ج- الجوانب الوجدانبة للهلف :}

- أن يهتم الطلاب بالعناصر البنائية و القيم الجمالية المكونة للبيئة . - أن يهتم الطلاب بالأهداف التدريسية في مناهج التربية الفنبة .

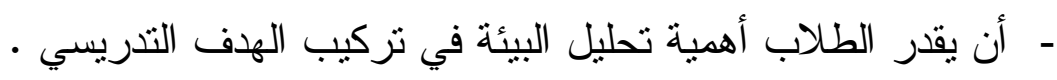
- أن يهتم الطلاب بترتيب جو انب الهدف التدريسي ترنيبا منطقيا . - أن يقبل الطلاب على تحليل وتركيب الأهداف التخريسية . - أن يقدر الطلاب أهمية المخزون في بناء بالأهداف التندريسية . - أن ينبنى الطلاب الهدف التدريسي في إعداد الدروس .

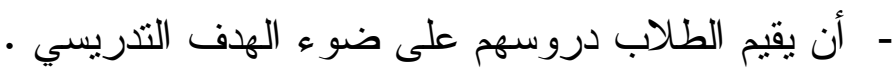
r ـ محتوى الوحدة التدريسية :

تضمنت الوحدة التدريسية المو اقف التثريسية السبع التالية :

$$
\text { أ- الموقف التدريسي الأول : }
$$

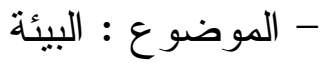
- الهدف : التعرف على البيئة - الزمن : - الزعتان

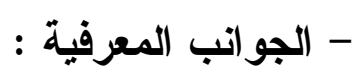
- أن يعرّت الطلاب مفهوم البيئة المرئية . 
- أن يتعرف الطلاب على مكونات البيئة .

- أن يتعرف الطلاب على فئات من العناصر البنائية المكونة للبيئة .

- أن ينعرف الطلاب على النظم المشكلة في البيئة .

- أن يتعرف الطلاب على القيم الجمالية في البيئة .

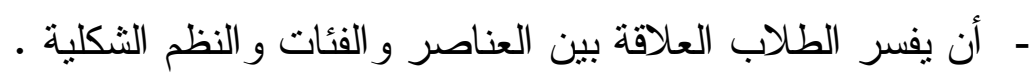

- - أن يدرك الطلاب العلاقة بين القيم الجمالية و النظم الثكلية في البيئة.

- أن يستقر أ الطلاب العناصر المكنة لمشهذ من مشاهد البيئة .

- أن يستقر أ الطلاب القيم الجمالية في مشهد من مشاهد البيئة .

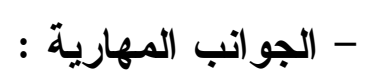

- أن بيترجم الطلاب المصطلحات و المفاهيم المرتبطة بالعناصــر البنائيــة

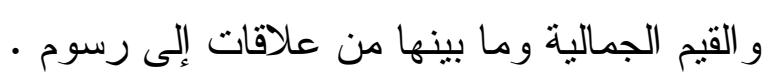

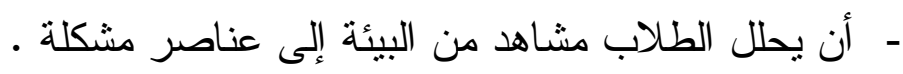

- أن يحلل الطلاب مشاهد من البيئة إلى فئات مشكلة .

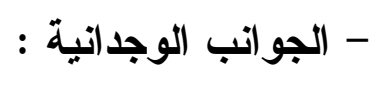

- أن يهتم الطلاب بالعناصر البنائية و القيم الجمالية المكونة للبيئة .

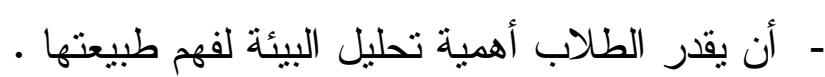

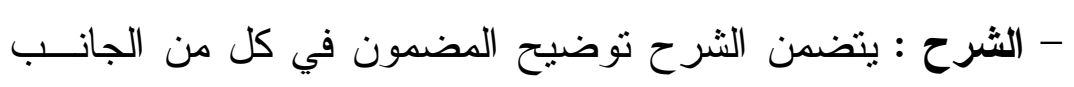

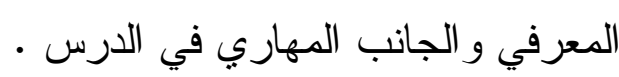

- طريقة التدريس : الإلقاء- الحوار و الدناقنتة - البيان العملـي حل المشكلات

- الخامات والأدوات : القلم الرصاص و الورق الأبيض . 
- أساليب التقويم:تتم على ضوء ما تحقق مــن الهـدف وجو انبــــ

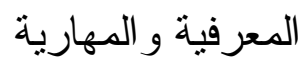

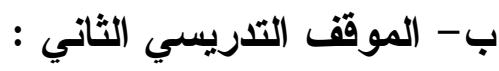

- الهلف : - الهوف -

فهم الأهداف التدريسية على ضوء الأسس العلمية و البيئية .

- الموضوع : الأهداف التذريسية

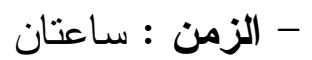

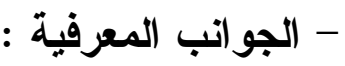

- أن يعرف الطلاب الأسس العلمبة للأهداف التدريسية في التربية الفنية

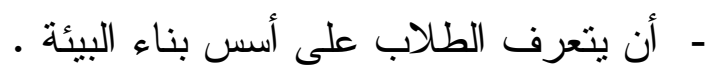

- أن يعرف الطالب العلاقة بين البيئة و الأسس العلمية للأهداف التدريسية

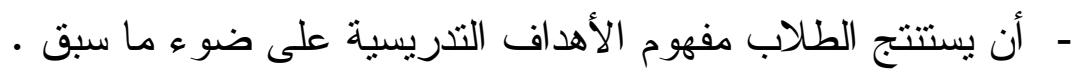

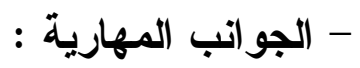

- أن يحلل الطلاب الأهداف التنريسية المعروضة عليه .

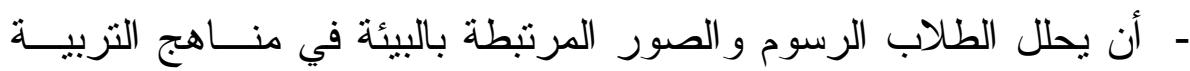

الفنية .

- أن يحلل الطلاب العناصر البنائية في البيئة . -

- أن يحلل الطلاب القيم الجمالية في البيئة .

- أن يكتب مصطلحات ومفاهيم على ضوء نو اتج التحليل الثنلي للبيئة

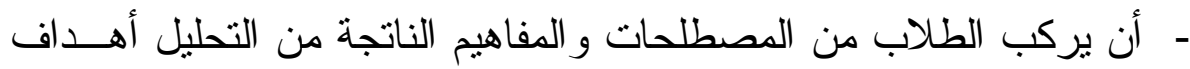

تدريسية فى مجال النطبيق.

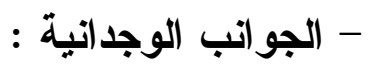

- أن يهتم الطلاب بالأهداف التدريسية في مناهج التربية الفنية . 
- الثرح : ينعرض المعلم لثرح الجانبين المعرفي و المهاري وما بينهما من علاقات منطقية.

- طريقة التدريس : الإلقاء - الحوار و المناقثة - حل المشكلات

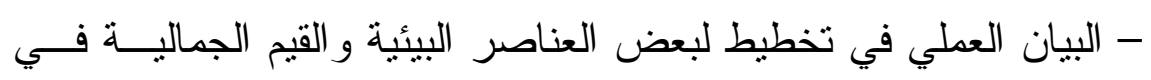
البيئة . - الخامات والأدوات : القلم الرصاص - الورق الأبيض •

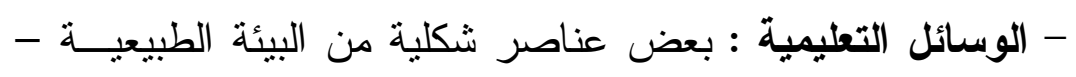

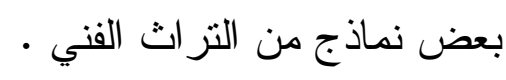

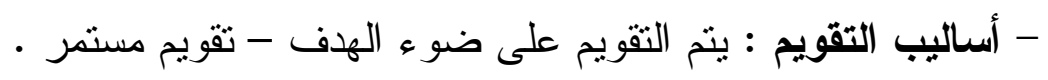
ج- الموقف التدريسي الثالث :

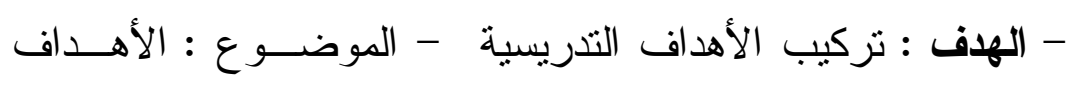
التذريسية

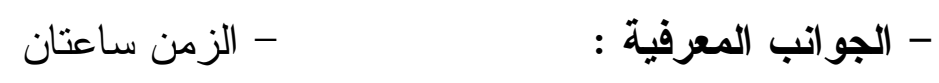
- - أن يفسر الطلاب العلاقة بين الأسس العلمية و الأهداف التدريسية .

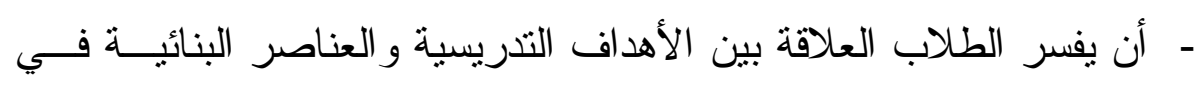

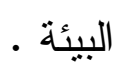

- أن يفسر الطلاب العلاقة بين الأهداف التدريسية والقيم الجمالية في البيئة

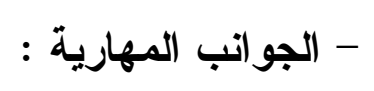

- أن يركب الطلاب أهدافا ندريسية تضمن أسس علمية (مستويات معرفية)

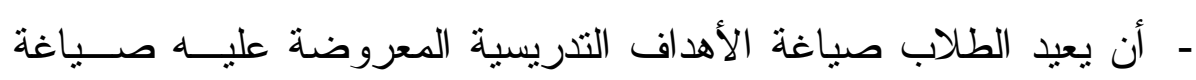
صحيحة

- أن يركب الطلاب أهداف تدريسية تتضمن عناصر بنائية في البيئة . 
- أن يركب الطلاب أهداف تدريسية تتضمن قيم جمالية وعناصر في البيئة فى مجال تطبيقى مختلف عن ما سبق.

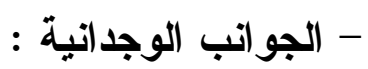
- أن يهنم الطلاب بترتيب الأهداف التخريسية .

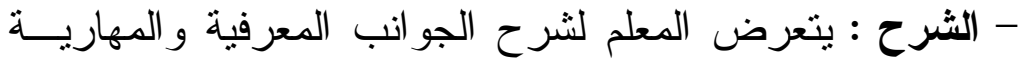

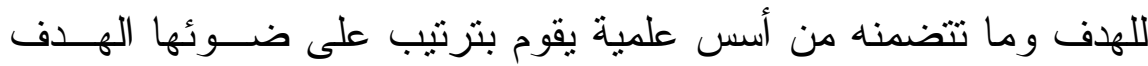
إضافة إلى العناصر البنائية والقيم الجمالية المتو افرة في البيئة .

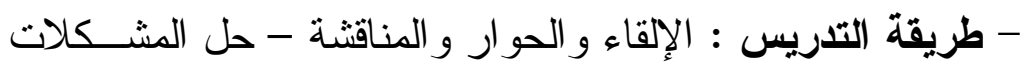
- البيان العملي الموضح لكيفيات تركيب الأهداف في صيغ علمية .

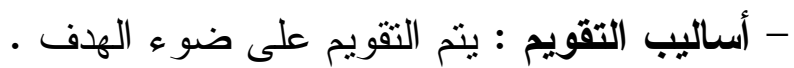
ع- الموقف التدريسي الرابع : - الهذف : تحليل وتركيب الأهداف التخريسية - الموضوع : شكــل ومضمون الأهداف التـريسية

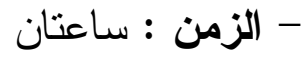

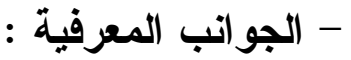
- أن يفهم الطلاب العمليات المرتبطة بتحليل وتركيب الأهداف التدريسية .

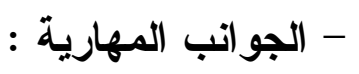

- أن يركب الطلاب الأهداف التنريسية من مفاهيم في مجالات التربية الفنية

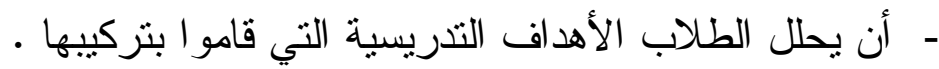

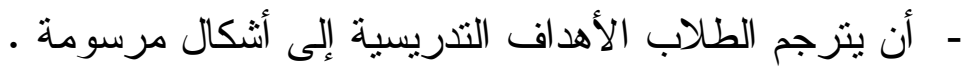
- أن يترجم الطلاب الأثكال المرسومة إلى أهداف تدريسية .

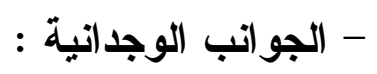

- أن يهتم الطلاب بتحليل وتركيب الأهداف التدريسية . 
- أن يقدر الطلاب شكل ومضمون الأهداف التنريسية .

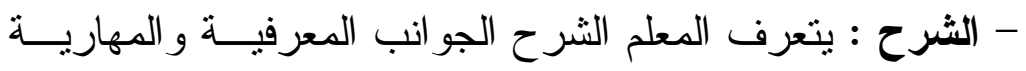

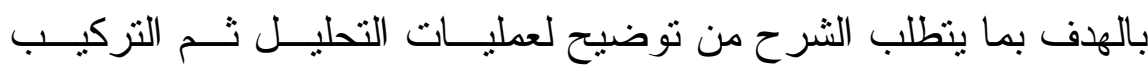

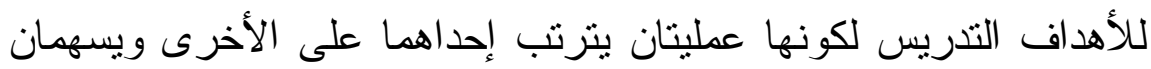

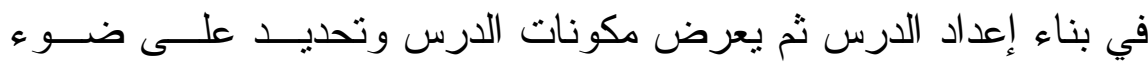
الهدف التدريسي فئاء إعاد

- طريقة التدريس : الإلقاء و الحوار و الدناقتشة - حل المشكلات .

- أساليب التقويم : ينم التقويم على ضوء الهوبه الهدف .

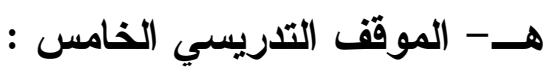

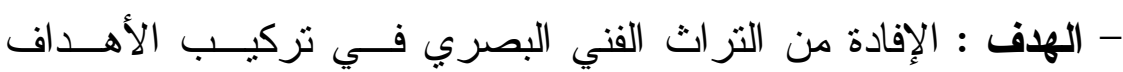

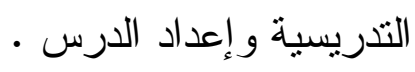

- الموضوع : التراث كمصدر للأهداف التنريسية

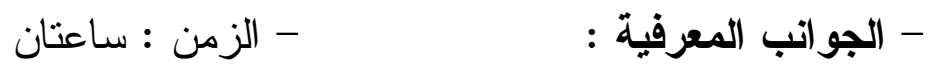
- أن يتعرف الطلاب على نماذج من التراث الفني البصري .

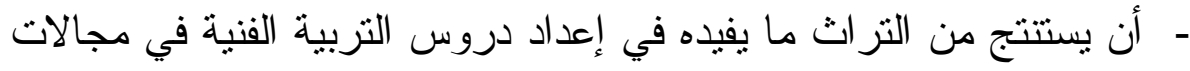
مختلفة - الجو انب المهارية :

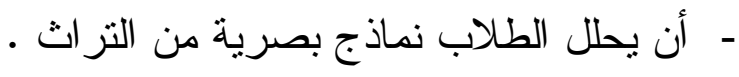
- أن يترجم الطلاب النماذج البصرية إلى مصطلحات ومفاهيم لفظية .

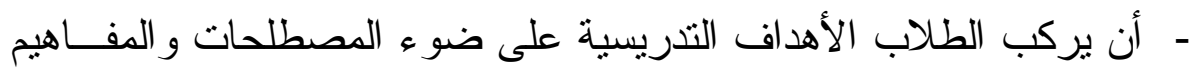
اللفظية

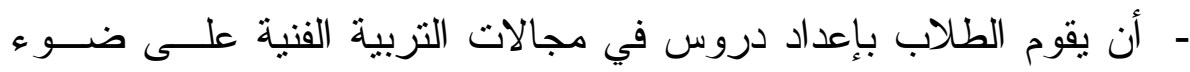

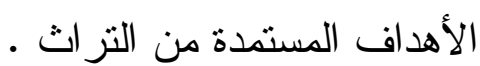


- أن يهتم التلميذ بالتراث الفني البصري و علاقته بالأهداف التنريسية ـ

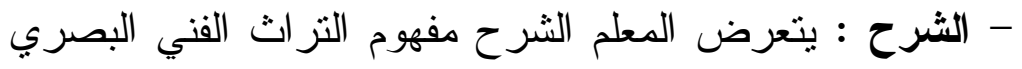

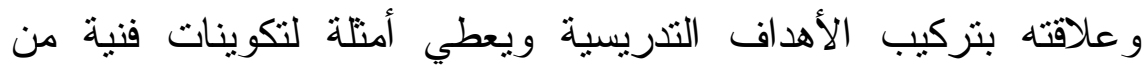
التزراث .

- طريقة التدريس : الإلقاء و الحوار و المناقثة - البيان العملـي حل المشكلات - الوسائل التعليمية : أعمال فنية مصورة من التراث .

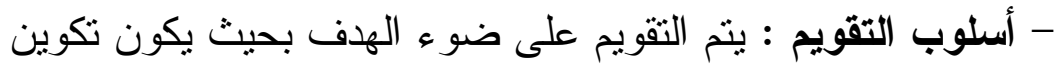

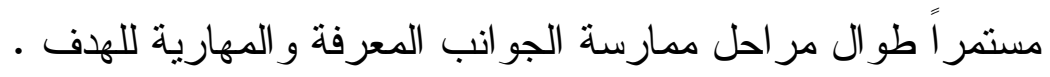

$$
\text { و - الموقف التدريسي السادس : }
$$

- الهدف:إعداد دروس على ضوء الأهداف التدريسية في مجالات

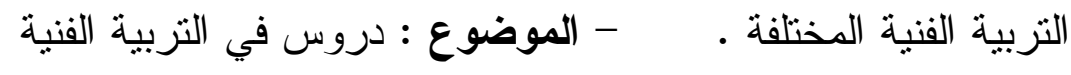

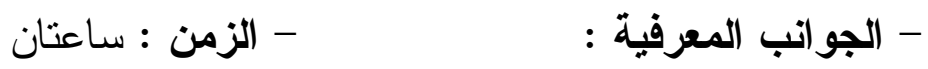
- أن يعرف الطلاب مفهوم إعداد الدروس في مجال التربية الفنية .

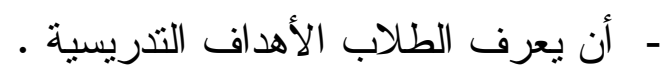
- أن يحدد الطلاب الهدف التدريسي . -

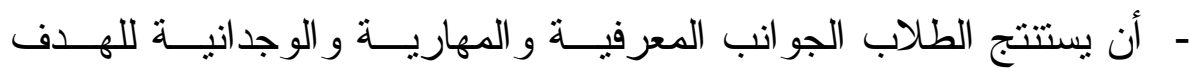

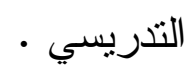
- أن يستتنج الطلاب العلاقة بين الهدف التدريسي وما يليه مـن إجــر اءات محققة له 
- أن يصيخ أهدافاً تدريسية في مجالات التزبية الفنية المختلفة . - أن يكتب إجر اءات الدرس المترتبة على الهدف التدريسي •

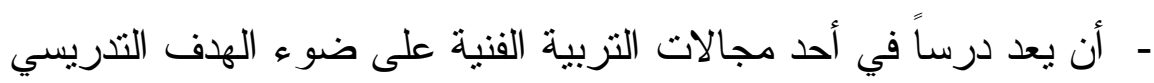

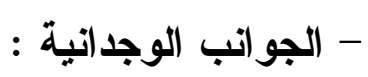
- أن يهتم الطلاب بقيمة الهدف التدريسي في إعداد الدروس :

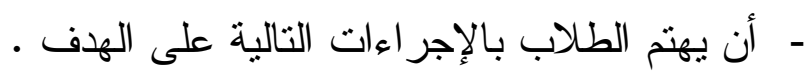

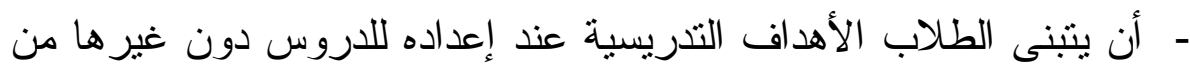

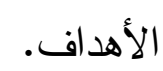

- الثرح : يتعرض المعلم الثر ح مفهوم الإعــداد للــدرس ثــم

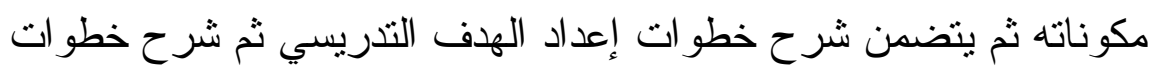
إعداد الدرس على ضوء الهدف التدريسي .

- طريقة التدريس : الإلقاء و الحوار و المناقثة - حل المشكلات .

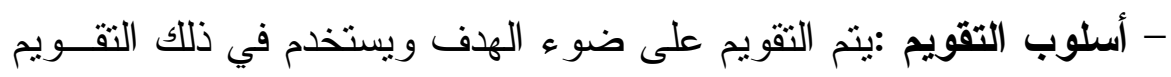

$$
\text { ز - الموقف التذريسي السابع : }
$$

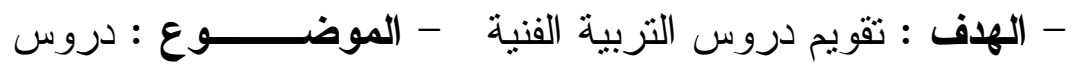

$$
\text { - }
$$




$$
\text { - الجوانب المهارية : }
$$

- أن يحلل الطلاب الدروس في أحد مجالات التزبية الفنية .

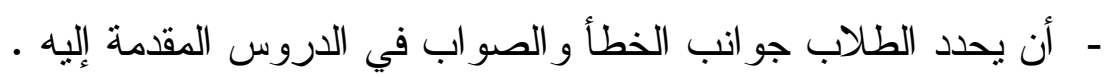
- أن يعيد الطلاب إعداد الدروس بصورة إجر ائية سلوكية . - أن يعالج الطلاب نقاط الضعف في دروس التربية الفنية المقدمة إليه.

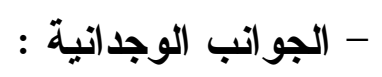

- أن يقدر قيمة التقويم في إعداد الدروس بصورة أنه : صحيحة .

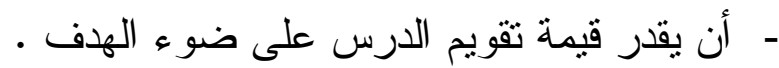

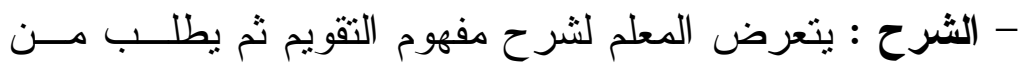

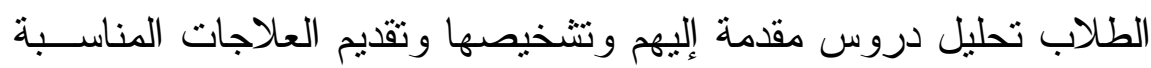
و الصحيحة لما يتضمنه من نواحي ضعف وقصور ثم بطلب منهم إعـداد

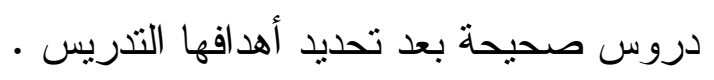

- طريقة التدريس : الإلقاء - الحوار و المناقثة - حل المشكلات

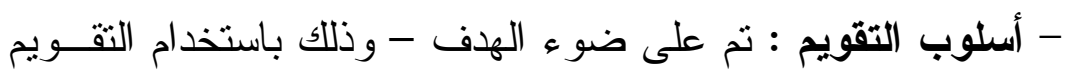
المستمر.

\section{رابعا : الأشطة المرتبطة بتدريس الوحدة :}

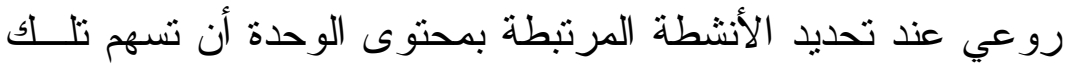
الأنشطة في تحقيق أهداف الوحدة ، فتضمنت الوحدة الأنشطة التالية :

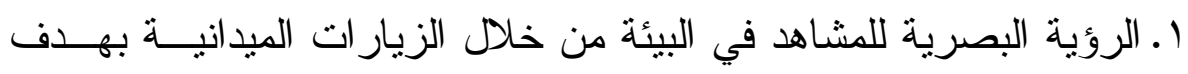

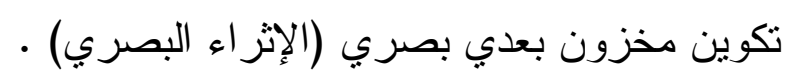

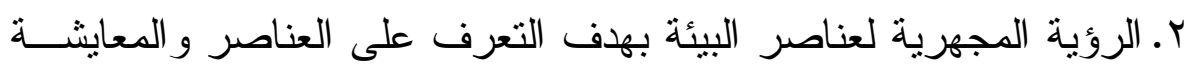
المحسوسة التي تتضمنها. 
r. رؤية الرسوم و الصور المطبو عة وتحليلها بهدف الوقوف على العناصــر

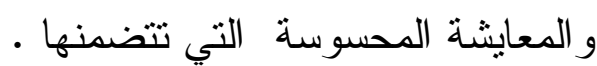

ع.ممارسة مهار ات الرسم لعناصر البيئة و التجارب اللونية بهــف تكـــين

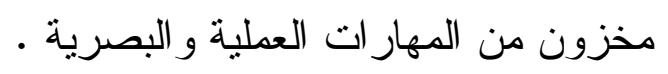

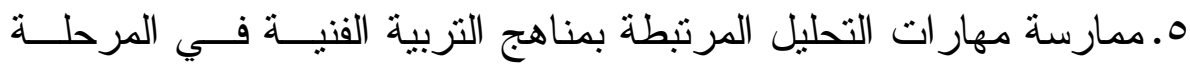

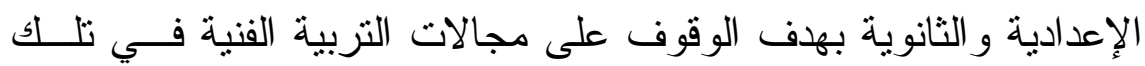

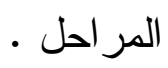

T. إنتاج وسائل تعليمية مرتبطة ببعض الأهداف التنريسية .

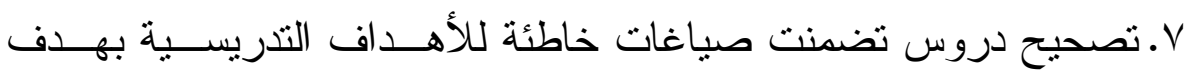

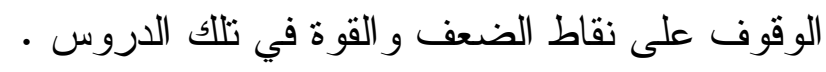

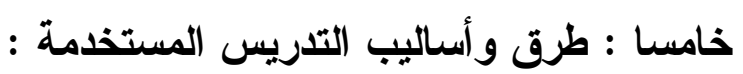

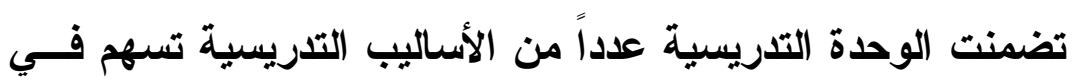

$$
\text { تحقيق هدف الوحدة هي : }
$$

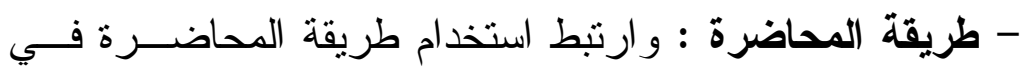
شرح و إيضاح الجو انب المعرفية و المهارية لدروس الوحدة وما تتضــــــهـ من مصطلحات ، ومفاهيم ومهار ات .

- طريقة الحوار والمناقشة : و وارتبط استخدام طريقــة الحسـوار و المناقثة في كثف ما لاى الطلاب من معلومات مؤكدة وصحيحة حسول الجو انب المعرفية و الدفاهيم المرتبطة بالعناصر المرئية و القيم الجمالية في

$$
\text { البيئة . }
$$

- طريقة حل المشكلات : و استخدمت هذه الطريقة فـي تعـديل معارف ومفاهيم الطلاب حول مكونات الهذف التنريسي القائمة على نو اتج 


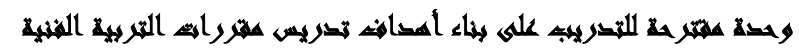

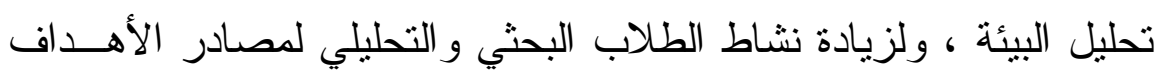

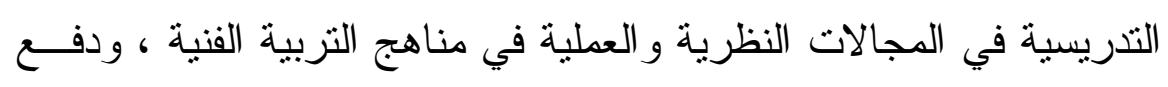

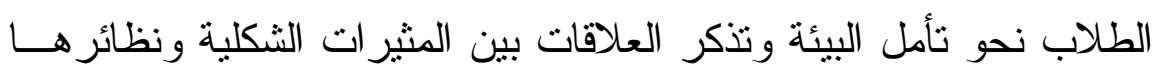

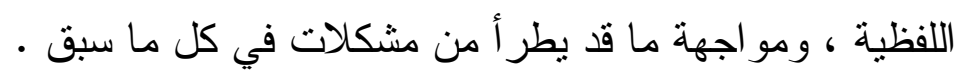

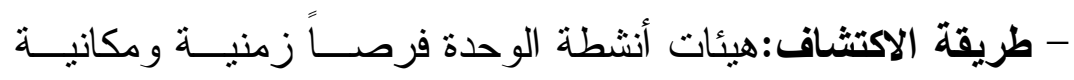

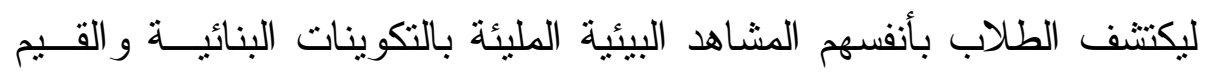
الجمالية في البيئة .

- طريقة التثخيص العلاجي : استخدمت هذه الطريقة في كثـــ فئس

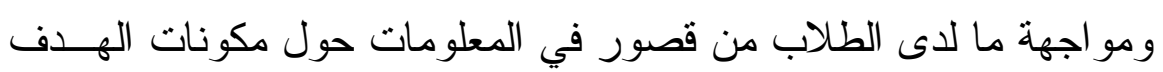
التذريسي ، وكذلك في مو اجهة عدم قدرتهم على مناظرة المثير ات المرئية

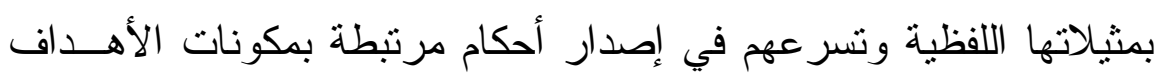

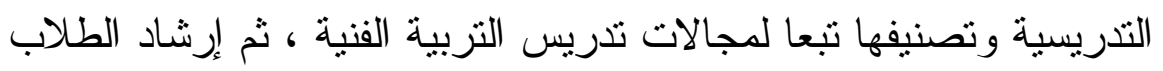
نحو كم الأهداف الصحيحة التي حققو ها وتصحيح أخطائهم بعد تحليلها . سادسا : أساليب التقويم :

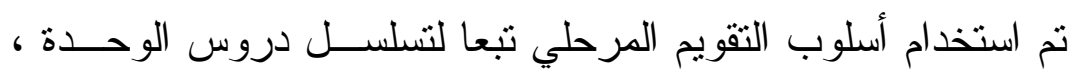

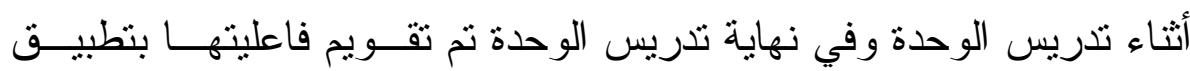

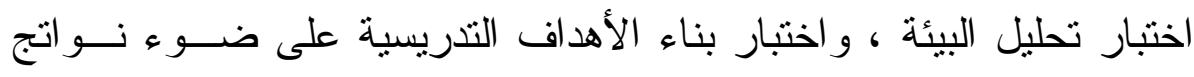
تحليل البيئة. 


\section{نتائج الار اسة :

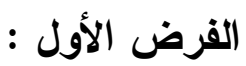

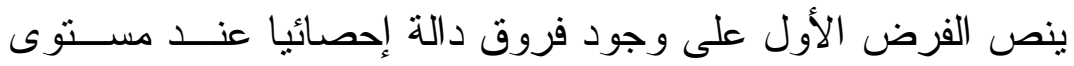

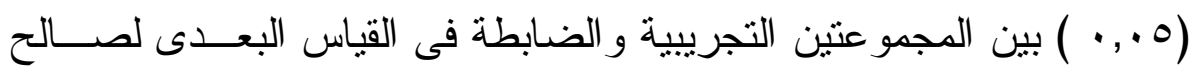
المجموعة التجريبية فى نو اتج تحليل البيئة .

جدول (๕)

\begin{tabular}{|c|c|c|c|c|c|}
\hline مستوى الدلالة & $ت$ & $\varepsilon$ & م & $\dot{ن}$ & المجموعات \\
\hline \multirow{2}{*}{ دال عند } & \multirow{2}{*}{$M, r Y$} & $\wedge, 1 \leq$ & $O \Lambda, \cdot \varepsilon$ & ro & تج. ق \\
\hline & & $\Lambda, 7)$ & $r q, \cdot 1$ & ro & ض.ع \\
\hline
\end{tabular}

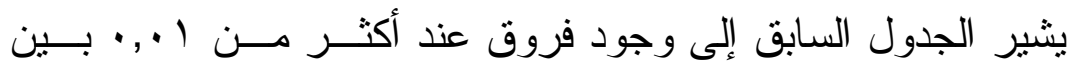

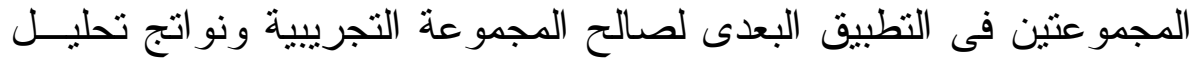

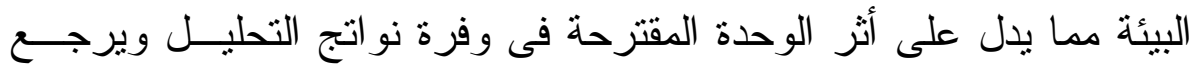
البحث هذه الفروق إلى ما أتاحته الوحدة المقترحة من أنثطة الرؤية التحليلية

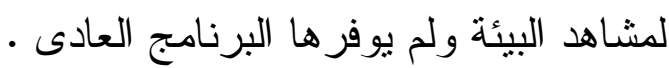

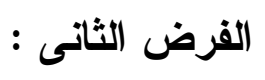

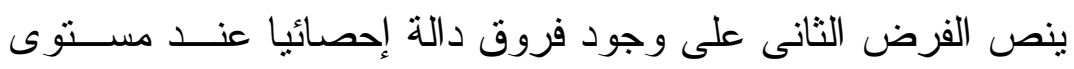

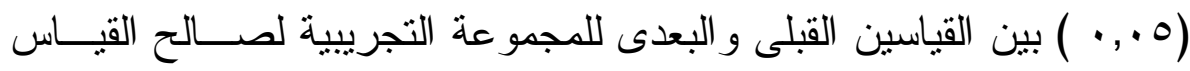

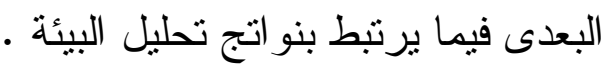

جدول (0)

\begin{tabular}{|c|c|c|c|c|c|}
\hline مستوى الدلالة & ت & $\varepsilon$ & م & $\dot{ن}$ & المجموعات \\
\hline \multirow{2}{*}{ دال عند } & \multirow{2}{*}{$17,7 \wedge$} & $\varepsilon$, or & $r\rceil, \wedge \wedge$ & ro & تج .ق \\
\hline & & $\Lambda, 1 \leq$ & $0 \wedge, \cdot \Sigma$ & ro & تج.ع \\
\hline
\end{tabular}




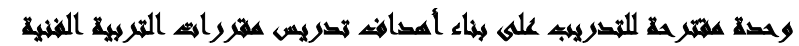

يشير الجدول السابق إلى وجود فروق دالة إحصائيا فى القياس القبلى

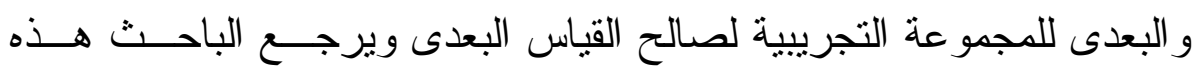

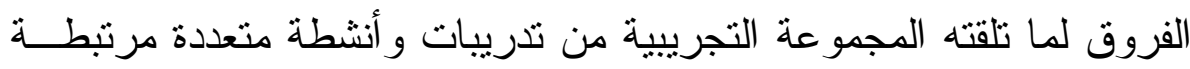

بمشاهدات البيئة لمو اقع متفر عة ومقارنات لفظية وحوار ات مقدمة من المعلم

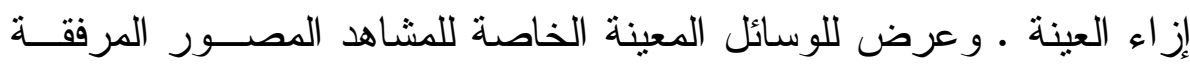
ورسمها وتمثيل الو اقع برسوم من الذاكرة وترجمة المشاهدات إلــى مفــاهيم

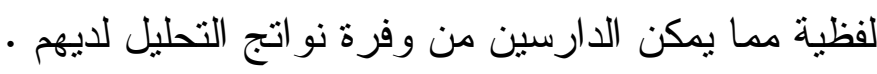

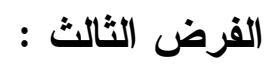

ينص الفرض الثالث على عدم وجود فروق دالــة إحصــائيا بــين القياسين القبلى و البعدى للمجموعة الضابطة فيما يرتبط بنو اتج التحليل البيئة.

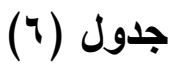

المتوسطات والاحر افات المعيارية وقيمة ت ومستوى الدالاة فى القياسين القبلى و البعدى للمجموعة الضابطة فيما يرتبط بنواتج تحليل البيئة

\begin{tabular}{|c|c|c|c|c|c|}
\hline مستوى الدلالة & $ت$ & $\varepsilon$ & r & ن & المجموعات \\
\hline \multirow{2}{*}{ غير دال } & \multirow{2}{*}{$1,1 \mathrm{~V}$} & $\{, \varepsilon \varepsilon$ & $r 7,9 T$ & ro & ق · تج \\
\hline & & $\Lambda, 7)$ & $r q, \cdot 1$ & ro & ع.تج \\
\hline
\end{tabular}

تشير النتائج السابقة أن عدم وجود فروق فـى متوســط درجـات

الطلاب فى المجموعتين التجريبية و الضـابطة برجع إلى مرور هما بخبــرات

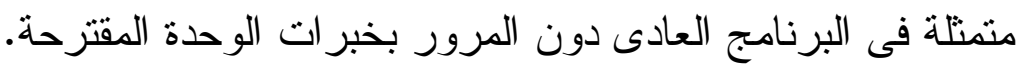




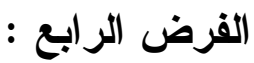

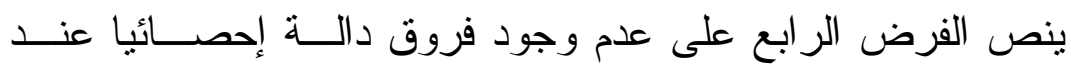

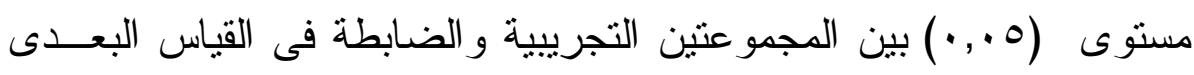

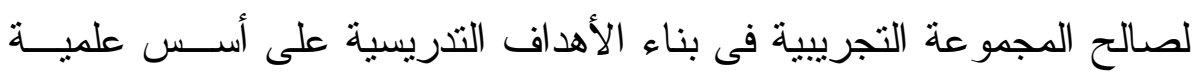

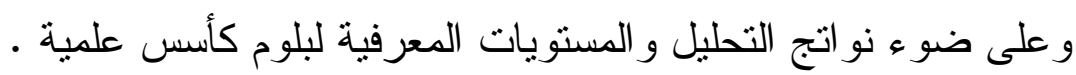

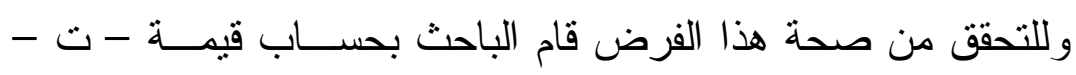
المتوسطات النطبيقية وجاءت النتائج كالآتى : جدول (v)

\begin{tabular}{|c|c|c|c|c|c|}
\hline مستوى الدلالة & 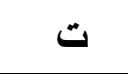 & $\varepsilon$ & م & $\dot{ن}$ & المجموعات \\
\hline \multirow{2}{*}{$\cdot, \cdot 1$} & \multirow{2}{*}{$r 1,79$} & $r q, \leqslant q$ & $r \leqslant \wedge, 97$ & ro & ع · تج \\
\hline & & $M, r \leq$ & $17 r, 94$ & ro & $\varepsilon$. \\
\hline
\end{tabular}

يشير الجدول السابق إلى وجــود فــروق دالــة إحصــائيا لصــالح

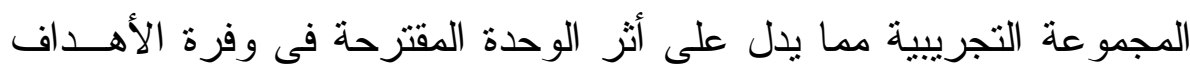
التدريسية ويرجع الباحث تلك الفروق إلى وفرة نواتج التحليل التى استفاد بها

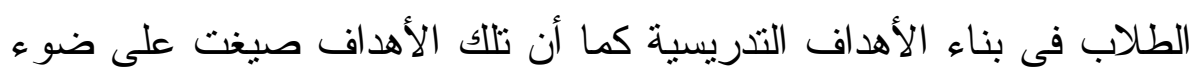
المستويات المعرفية جميعها بداية من التذكر حتى التقويم مما يدعم وفرتها.

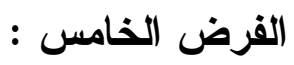

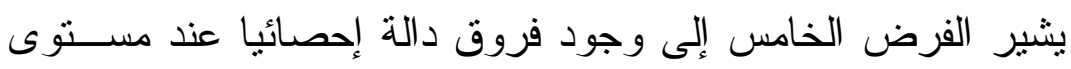

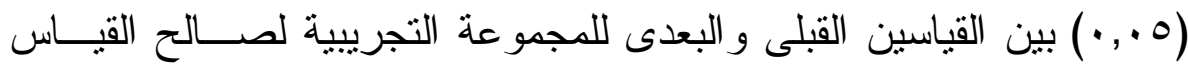

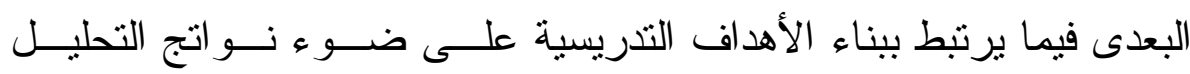

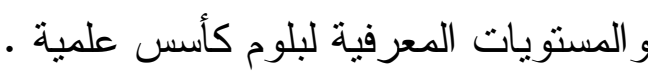




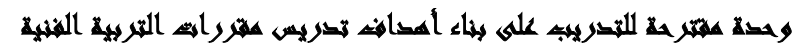

جدول (^)

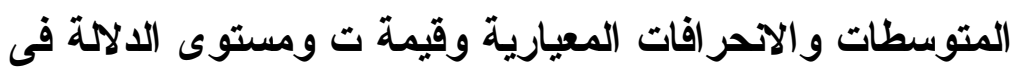

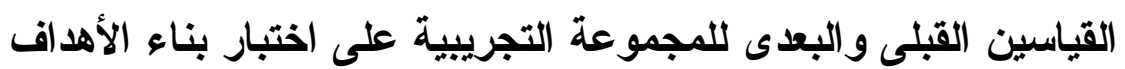

التذريسية

\begin{tabular}{|c|c|c|c|c|c|}
\hline مستوى الدلالة & $ت$ & $\varepsilon$ & م & ن & المجموعات \\
\hline \multirow{2}{*}{ أقل من } & \multirow{2}{*}{$r_{\cdot, r_{0}}$} & $1 . r q$ & 1ד,YאA & ro & . تج \\
\hline & & $r 7, \leqslant q$ & $r \leqslant \Lambda, 90$ & ro & c- \\
\hline
\end{tabular}

يشير الجدول السابق إلى وجود فروق دالة إحصائيا فى القياس القبلى

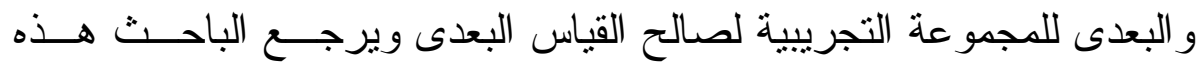

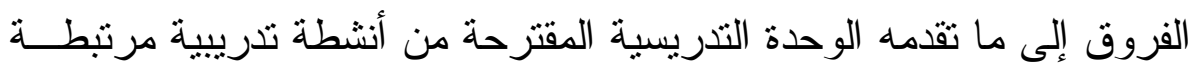

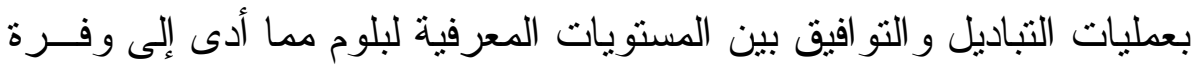

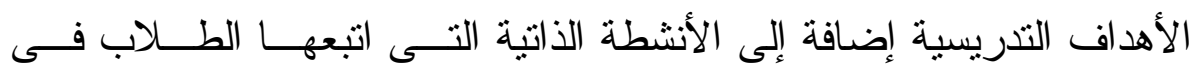

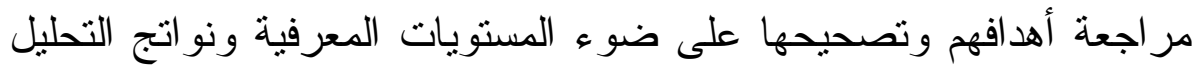
المناسبة لها .

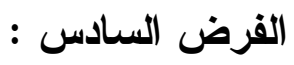

ينص الفرض السادس على وجود فروق دالة إحصائيا بين القياسـين

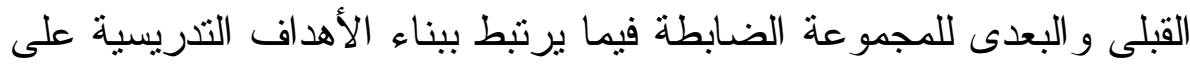
أسس علمية و على ضوء نو اتج التحليل. 
جدول (9)

المتوسطات والاحمرافات المعيارية وقيمة ت ومستوى دلاتها فى القياسين القبلى والبعدى للمجموعة الضابطة فيما يرتبط بيناء الأهداف على ضوء نواتج التحليل والمستويات المعرفية لبلوم كأسس علمية

\begin{tabular}{|c|c|c|c|c|c|}
\hline مستوى الدلاة & ت & $\varepsilon$ & م & $\dot{ن}$ & المجموعات \\
\hline \multirow{2}{*}{ غير دال } & \multirow{2}{*}{$1, \varepsilon r$} & $M, r V$ & 109,17 & ro & ، ض. \\
\hline & & $M, r \leq$ & $17 \pi, 94$ & ro & ض \\
\hline
\end{tabular}

يشير الجدول السابق إلى وجود فروق دالة إحصائيا فى القياس القبلى

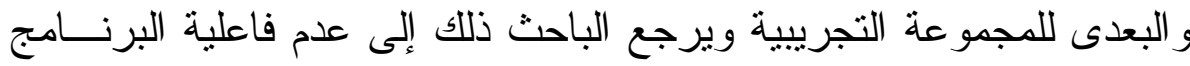
العادى فى بناء وصياغة الأهداف التعليمية لدى الطلاب .

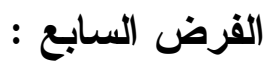

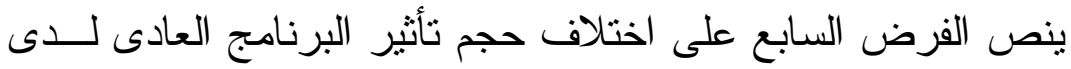

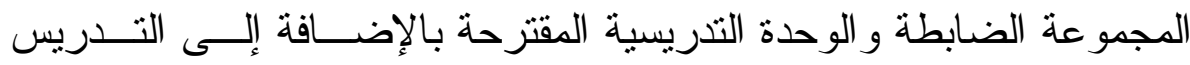
العادى لدى المجموعة التجريبية فى نو اتج تحليل البيئة .

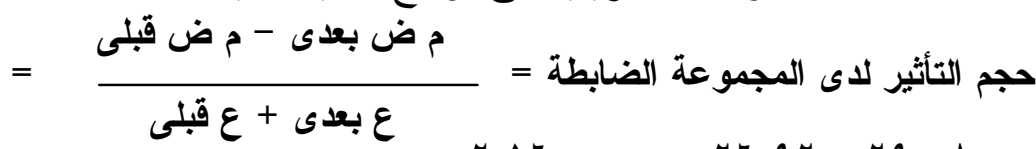
., $170=\frac{r, 14}{1 r, .0}=\frac{r q, q r-r q, .1}{\varepsilon, \varepsilon \varepsilon+\Lambda, 71}=$

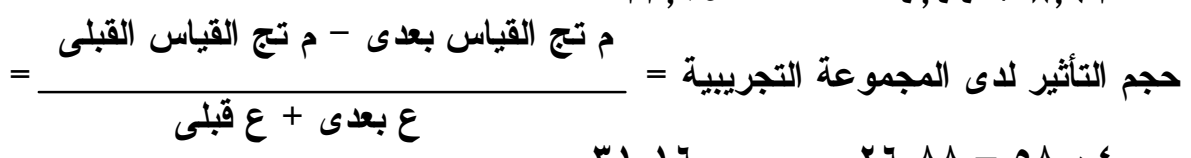

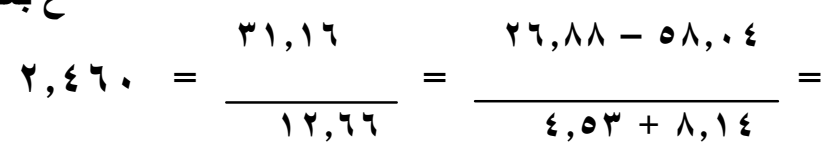

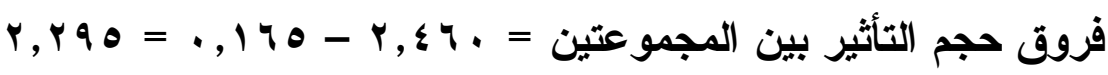




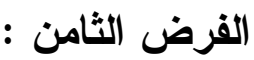

ينص الفرض الثامن على اختلاف حجم التأثير بين التنريس العادى

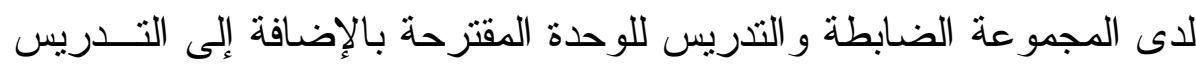

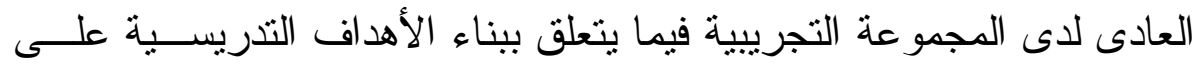

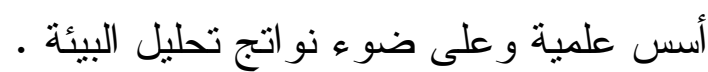
وللتحقق من قيمة الفرق تستخدم معادلة حجم التأثنير

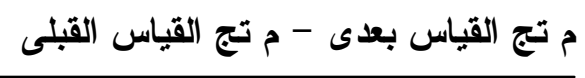
$=$

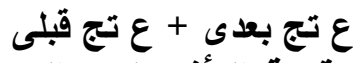

حساب قيمة التأثير لدى اعجى المجموعة الضابطة : 109,17-17r,94

$\cdot, 19 \leq=$

$$
\text { Ir,rV+ Tr,r }
$$

حساب قيمة التأثير لاى المجموعة التجريبية : 1 $4 r, r \wedge-r \leqslant \Lambda, 94$

$$
0, \vee \text { เ }=
$$

$$
1 \cdot, r q+r q, \varepsilon q
$$

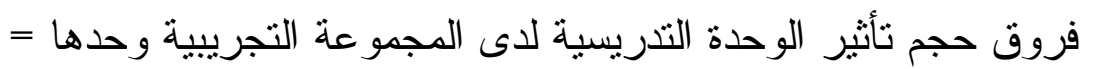

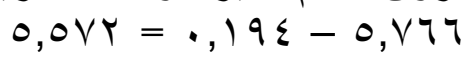

$$
\text { تعليق : }
$$

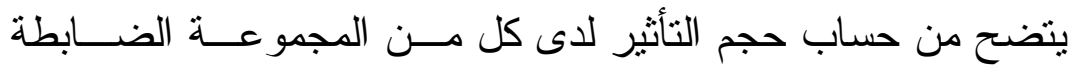

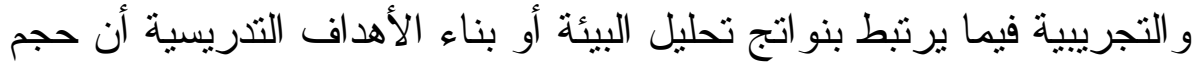

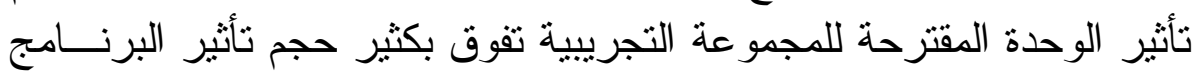

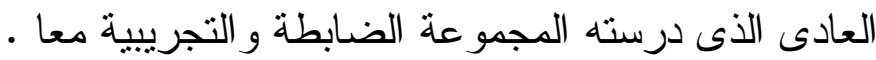
جدول الأهداف المنتجة

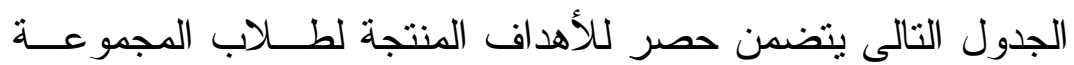
التجريبية و المجموعة الضابطة ، موزعة على على مقرر لات التربية الفنية الأثنى

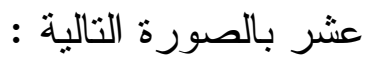




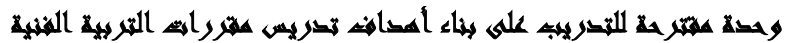

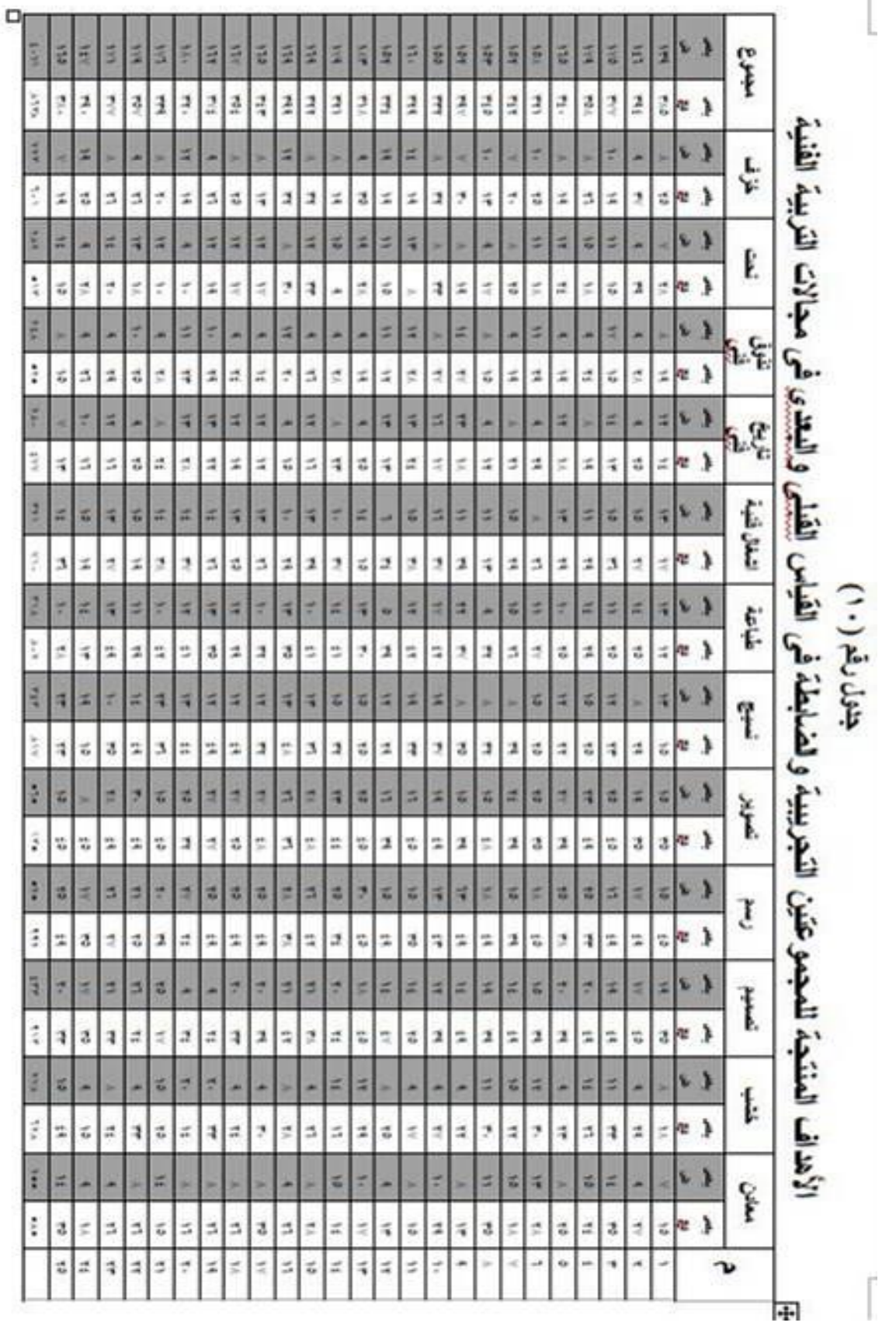




\section{التحليل الوصفى لنتائج الاراسة :}

من خلال الجدول (^) يتبين من الجدول السابق تباين أهداف الطلاب الطي

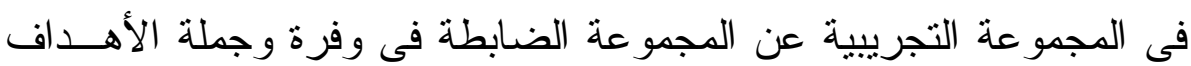
فى مجالات التربية الفنية لصالح المجموعة التجريبية فى القياس البعدى .

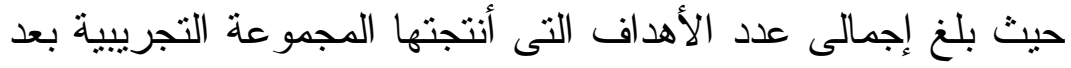

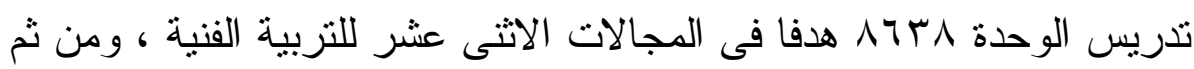

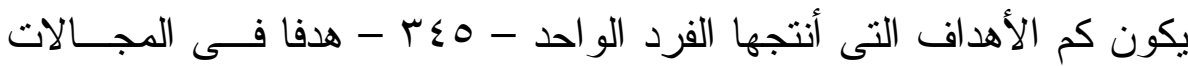
الاثتى عشر للتربية الفنية نم إنتاجها طو ال تدريس الوحدة المقترحة .

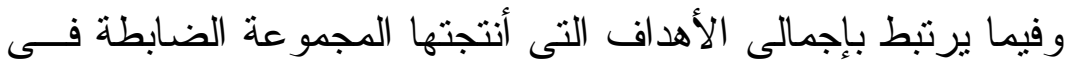

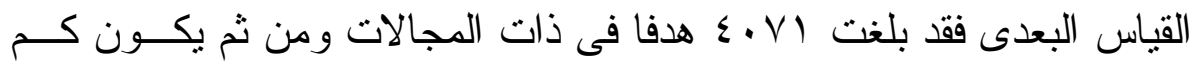

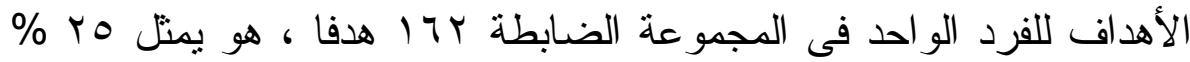

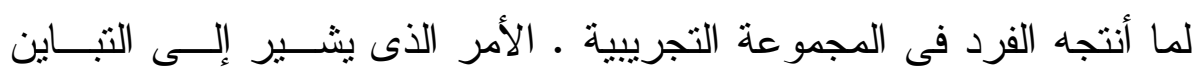

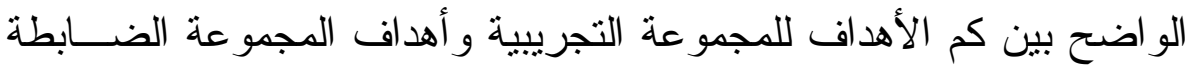
لصالح المجموعة التجريبية ـ و الذى يؤكد فعالية الوحدة التنريسية المقترحسة

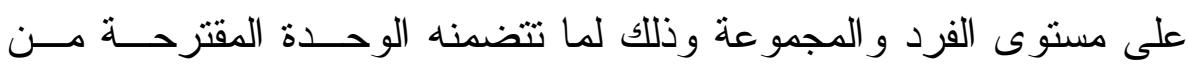
تدريبات للطلاب المعلمين ارتبطت بتحليل البيئة و الاستدلال عن ما شـــاهدوه

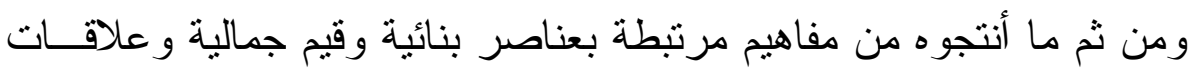

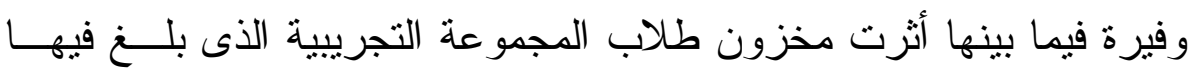
إنتاج الفرد للأهداف يفوق إنتاج الفرد للأهداف فى المجموعة الضرن الضابطة بفارق كبير فى مجالات التربية الفنية الاثنى عنر • لالترد 


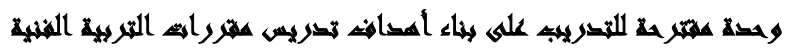

وما يلى جدول ترنيب الأهداف المنتجة ترتيبا تبعا لعددها عند طلاب

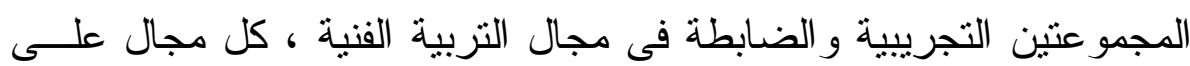

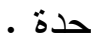

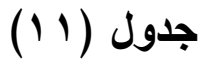

\begin{tabular}{|c|c|c|c|c|c|}
\hline \multicolumn{2}{|c|}{ عدد الأهداف تنازليا } & \multirow{2}{*}{ المجال } & \multicolumn{2}{|c|}{ عدد الأهد اف تنازليا } & \multirow{2}{*}{ المجال } \\
\hline هدف & 070 & & هدف & $1 . r 0$ & \\
\hline هدف & oro & r- الرسم & هدف & 994 & r- الرسم \\
\hline هدف & ETr & r- التصميم & هدف & $91 \pi$ & r- التصميم \\
\hline هدف & $r \leq r$ & ع - النسيج & هدف & NIV & ع - النسيج \\
\hline هدف & rr & 0- الطباعة & هدف & $\Lambda \cdot r$ & 0- الطباعة \\
\hline هدف & M1A & ז- الأشغال الفنية & هدف & vi. & ؟- الأشغال الفنية \\
\hline هدف & rAT & V- أنشغال الخشب & هدف & TrA & V- أنشغال الخشب \\
\hline هدف & rA. & ^- الخزف & هدف & 7.1 & ג- الخزف \\
\hline هدف & rVA & 9 - المعادن & هدف & 010 & 9 - المعادن \\
\hline هدف & roo & • ا - التذوق الفنى & هدف & 070 & • 1 - التذوف الفنى \\
\hline هدف & $r \leq \Lambda$ & 11 - النحت & هدف & 011 & 11 - النحت \\
\hline هدف & rTt & r ا - التاريخ الفنى & عدف & $\varepsilon V V$ & rا - التاريخ الفنى \\
\hline هدف & vi & المجموع & 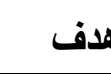 & A & المجموع \\
\hline
\end{tabular}

وبمقارنة عدد أهداف المجموعة التجريبية و المجموعــة الضــابطة

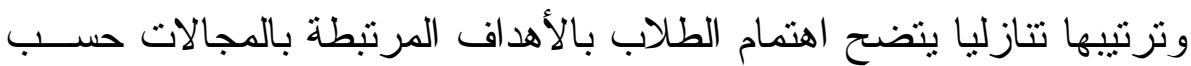

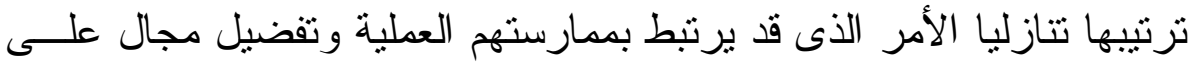

آخر وهو ما يمكن التعرض له فى دراسات أخرى قد تجيب على التســاؤل 
التالى - لماذا يفضل بعض طلاب التربية الفنية بعض المجالات النظرية أو

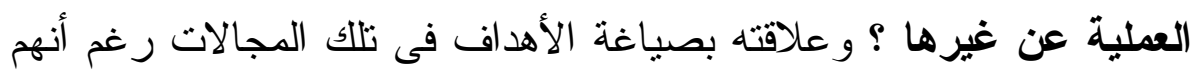
منوطين بالتمكن من تعليم وتعلم كل المجالات كونهم معلمين تربية فنية لكل

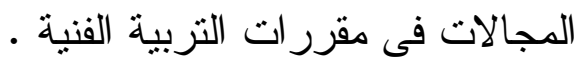
توصيات الدراسة والبحوث المقترحة - توصى الدر اسة و اضعى المناهج أن يضعو ا فى اعتبار هم فى المقام الأول

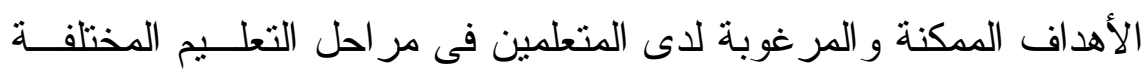

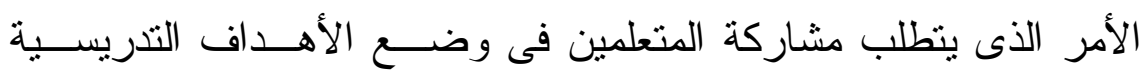
القادرين على تحقيقها تبعا لقدر اتهم الفنية .

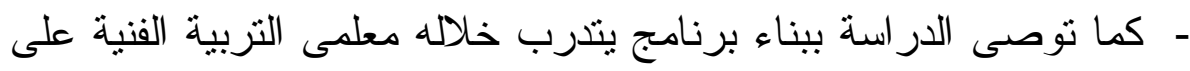

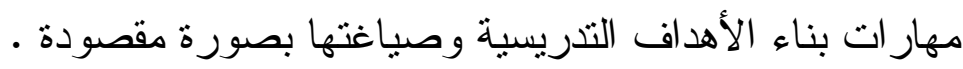

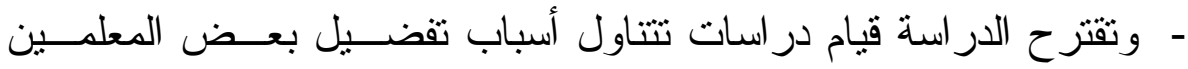

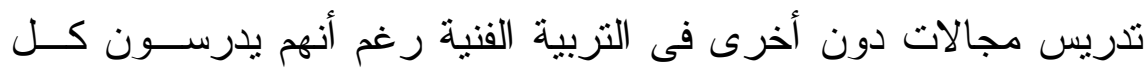

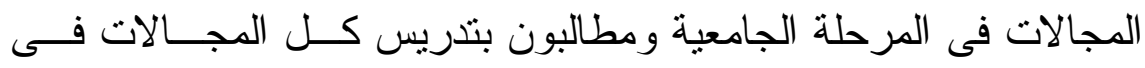

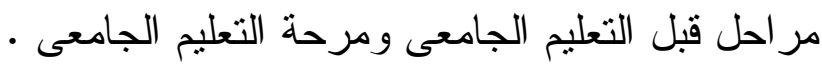

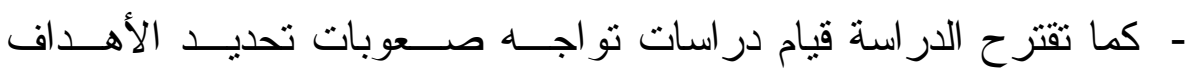

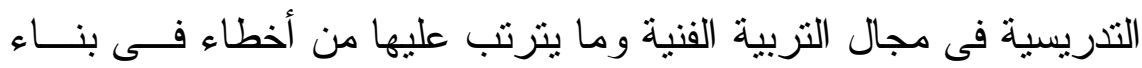

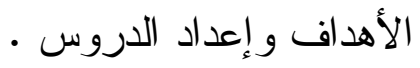
- كما تقترح الدر اسة قيام در اسات تتناول مداخل متعددة وجديدة لصـيـياغة

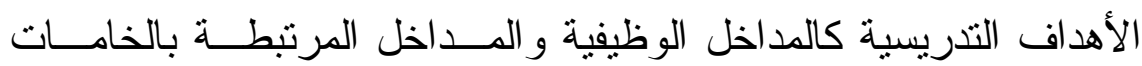

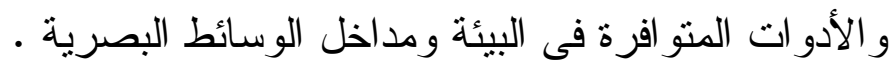




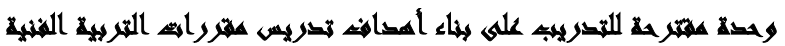

\section{ملحق رقم (1) \\ اختبّل نواتج التُطيليل}

سؤل الأتبَار :

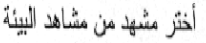

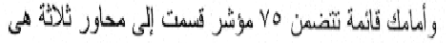

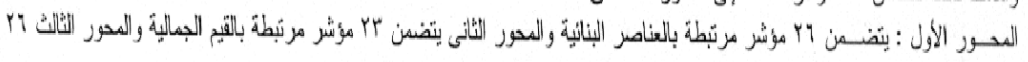

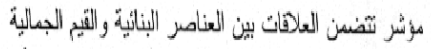

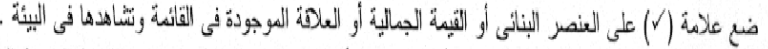

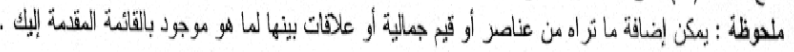

نواتج تحليل البينة

\begin{tabular}{|c|c|c|c|c|c|}
\hline المدرز الثلأل & i & العزور الثلأي & 1 & العدور الأول & P \\
\hline البلألأت & & القبم الجمالية & & 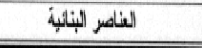 & \\
\hline 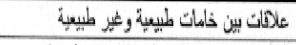 & 1 & 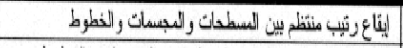 & 1 & النطوط طلفكرة: & 1 \\
\hline 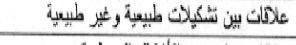 & $r$ & 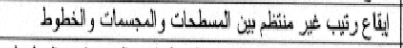 & +1 & النطوط لائرية & $r$ \\
\hline 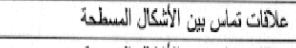 & $r$ & 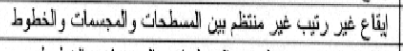 & $r$ & الخطوط المركبة & $r$ \\
\hline 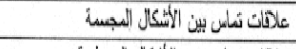 & $!$ & ليقاع غير رئب منظم بيز السطدان ولنجسات رالنطوط & 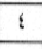 & الخطوط لليلزورنية & $i$ \\
\hline 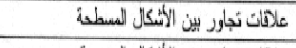 & 0 & 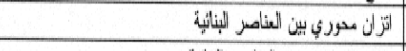 & $\cdot 0$ & الخطوط الإنبقية. & $\because$ \\
\hline علآات تجارز بين الأشكال العجسة: & 1 & اتزّان إثعاثي بين الغناهر البنائية & 1 & الخطرط لزرلبية & 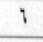 \\
\hline 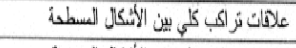 & $\begin{array}{ll} \\
\end{array}$ & التزان بركزي بين العناصز البائلية & Y & النطوط لعالثة & v \\
\hline 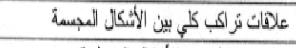 & $A$ & اتز الن وشبى بين العاهر البنائية & 1 & الخطوط لفخلة: الثنانات & A \\
\hline علاقات تألمع يين الأثكال السطدة & 4 & 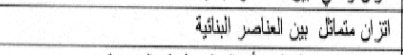 & 9 & 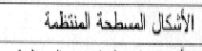 & 9 \\
\hline 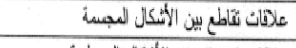 & 1. & 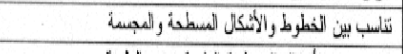 & 1. & 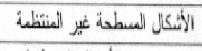 & 1. \\
\hline 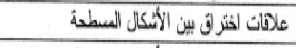 & 11 & تنأسب ين الأنكال، السطدة الملونة رغير الملونية & 11 & فز اغات بين الأشكال السطودة & 11 \\
\hline عالهات اختر أُ بين الأُشكال العجسية & 14 & 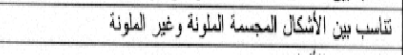 & ir & فزراغاك بين الأثكال المجسة" & 14 \\
\hline 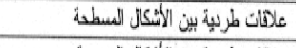 & ir & نثنّب بين الألوان & $1 \%$ & هلأسس خُشة & ir \\
\hline عالهات طرلية بينز الأئكال المبسة & $1:$ & تناسب بين لملأيس & I! & مالنس ناعiأ & is \\
\hline 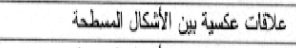 & 10 & تنتاسب بين لخطوط & 10 & تقلطة سنجسعة & 10 \\
\hline 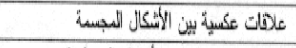 & 17 & انتاسب بين النزاغات & 11 & تقطة سترنة & 17 \\
\hline 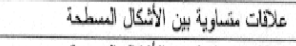 & ix & 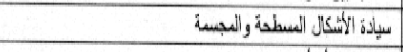 & IV & ألوان ساتئة & iv \\
\hline 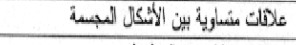 & 11 & سبيأة لون أو أكتر & $1 \mathrm{~A}$ & 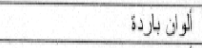 & iA \\
\hline عالهات شئك بين الخطوط & 19 & بيلاة ملمن ها & 14 & ألوان مدائٌ & 19 \\
\hline عالثات تر اكيب جزئى بين الخطوط & $r$. & 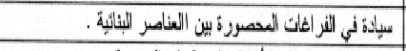 & $r_{1}$ & ألوان بركبة & r. \\
\hline عالهات ترأئيب جزئى يبين السياداث & $r$ & وحدة بين الخطوط رالأسئل المسطدئ رلبسة. & 11 & الولز مكلة & ri \\
\hline عالثات من الثز اغات بين النطوط & $r y$ & ودذة بين الألوان & $r y$ & ألوان أسلية & $\pi$ \\
\hline علاذات من القزر اغات بين الجسسات & $4 \pi$ & وحدة بين الهلانس & $r \mu$ & ألوان ثانية & $r i$ \\
\hline علآات من الفز اغات بين النطورو والمسادات & $r !$ & & & ألوان غائثة & ro \\
\hline علآثات من الفز اعات بين المشادات والمجسمات & Yo & & & الوبان مeفية & m \\
\hline عالثات لونبة بين للنئمر & 14 & & & & \\
\hline
\end{tabular}




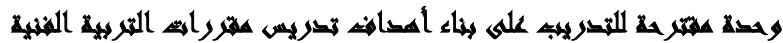

\section{ملحن رقم (Y)}

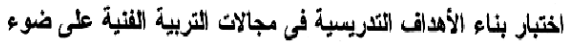

الأسس العلية ونواتج نحليل البيئة لطلاب التربية الفنبة

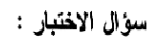

أماكك جلول ينضسن محورين :

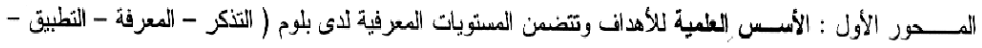

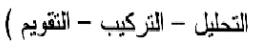

المحور الثـــانى : ويتضمن (V0) مؤشر يمثلوا نواتج تحليل البيئة

أعد الأهداف التكريسية المكنة فم مجالات التريبة الفنية على ضوء الأسس العلية ونواتج التحليل .

\begin{tabular}{|c|c|c|c|c|c|}
\hline تايع نواتئ التحليل & e & نواتئ الثطليل & , & الأسس العلفية & p \\
\hline كتاسب بين الالولن & $r 9$ & |الخطرط المكسرة & 1 & التئزي & 1 \\
\hline تناسب بين الملادس & $\varepsilon$ & الخطرط الدائزية & $r$ & المعزنة & r \\
\hline تتامب بين الخطرط & £! & الخطرط المركية & $r$ & الثطبيقي & 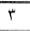 \\
\hline تتاعب بين النز اغات & $\mathbf{E}$ & الخطرط الحلزونية & $\vdots$ & 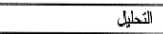 & $i$ \\
\hline سيادة الأسكال السططية والمجسية & ET & الذطرط الأنتية & $\circ$ & الثركيب & $\circ$ \\
\hline سياد: لون او أكثر & $\xi \vdots$ & الخطوط الر أسية & 1 & الثقويج & 1 \\
\hline سيادة ملعس ما & ईo & الخطرط العائلة & v & & \\
\hline سبادذّ في القراغات العصصورة بين النغاصر البنائية . & $\$ 1$ & |الخطرط الفنتلفة الثخانات & $A$ & & \\
\hline 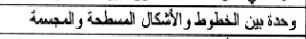 & $\xi y$ & |الأشكالن المسطدة النثظة & 9 & & \\
\hline وحدةُ بين الآلو اذن & th & 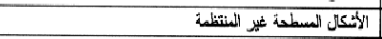 & 1. & & \\
\hline وحدثة بين الملاكس & $\$ 4$ & |الأسكال السططدة اليركية & 11 & & \\
\hline غاهات بين خامات طبيعية رغير طيعية & o. & 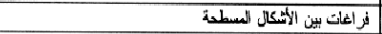 & ir & & \\
\hline علافات يين تشكيلات طبيعية وغير طبيعية & .1 & | فراغات بين الأكالال المجسة & 14 & & \\
\hline 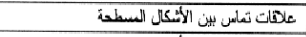 & $a^{4}$ & 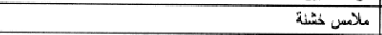 & $1 !$ & & \\
\hline 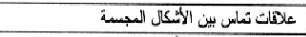 & or & ملأمس ناعثة & 10 & & \\
\hline معاذأت تجارر بين الأشكال السطقية & oi & 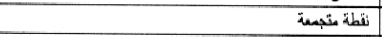 & 11 & & \\
\hline عالآثات تجاور بين الأثكال، المجسة & $\infty$ & 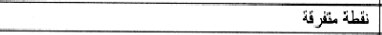 & iv & & \\
\hline 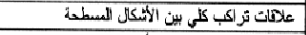 & 99 & | - أوان سافنية & in & & \\
\hline 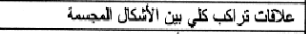 & ay & | أو ان باردة. & 19 & & \\
\hline عالهات تقاطع بين الألمكال المسطدة. & 01 & 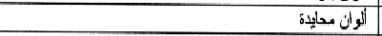 & Y. & & \\
\hline 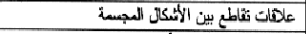 & 89 & 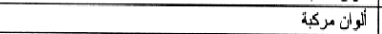 & $r_{1}$ & & \\
\hline عالهات الختر اق بين الأنسكال المسطدة & ?. & | أولان مكلة & $\pi$ & & \\
\hline 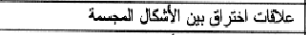 & 11 & | أوان أسياسية & $r$ & & \\
\hline 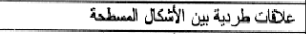 & $7 Y$ & أوإن ثتائية & Yt: & & \\
\hline علاكات طر بية بين الأسكال المجسة & $4 \pi$ & | أوان غانقة & $Y_{0}$ & & \\
\hline علاذات عكسية يين الأثكال السططدة & 74 & |ألوان معنُة & i: & & \\
\hline 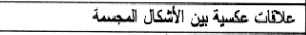 & 70 & 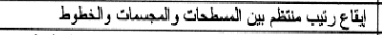 & YY & & \\
\hline إلاكات منساوية بين الأسكال السطدة: & 94 & إيتاع رتيب غير منتظم بينئ المسطحات والمجسات والخطرط & $r / 4$ & & \\
\hline 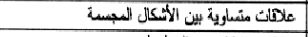 & iv & | إيتاع ثير رتيب غير منظط بيز المسطدات والتجسعات والخطوط & T! & & \\
\hline عالهاث تشابك بين الخطوط & 31 & 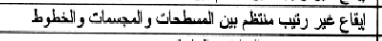 & +1 & & \\
\hline عادهات تر اكيب جزنى يين النفطوط & 19 & التزان محوري بين لعناصر البيائية & $r 1$ & & \\
\hline علادات تراكيب جزنى بين السياحات & $\mathrm{v}$, & التزان إبعاعي بين العناصبر البائية & TY & & \\
\hline علادات سن الفر اغات بين الخطرط & VI & التزان مركزي بين العنامبر البائية & $r T$ & & \\
\hline علاهات من الغراغات يبين المجسمات & VY & التزان وشي بين العنامر الينانية & $r !$ & & \\
\hline علاذات من الفزاغات بين الخطوطور المعاحات & Vr & 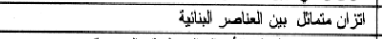 & To & & \\
\hline عالات منز الفوزاغات بين العساحات والعجسمات & $v \leqslant$ & تتاسب بين لخطرطو الأئكال المسطد: والمجسمة & TM & & \\
\hline عالآتات لونية بيئ العنامر & Yo & نتاسب بين الأئيكال المسطحدة العلونة وغير الملونية & TY & & \\
\hline 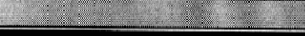 & 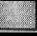 & 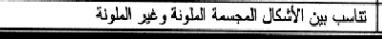 & $T \Lambda$ & & \\
\hline
\end{tabular}




\section{المراجع النغر}

(1) أنور محمد الثرقاوى (Y999 (19): علم النفس المعرفى المعاصر ، القاهرة ، الأجلو

$$
\text { المصرية . (1) }
$$

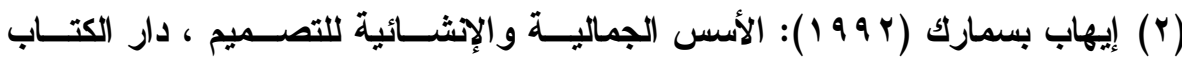

$$
\text { المصرى للطباعة و النشر ، القاهرة. }
$$

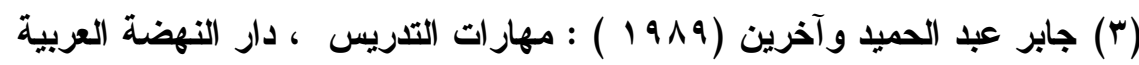

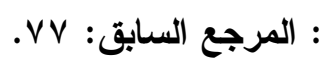

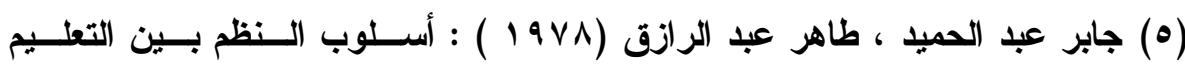

$$
\text { والتعلم، دار النهضة العربية ، القاهرة . }
$$

(†) صلاح الدين عرفة ( ب99 19 ) : " فاعلية استخدام الوحدات المصغرة ( الموديول) في إكساب الطلاب المعلمين مهارات صياغة الأهداف التعليمية ، بحث منشور مجلة

$$
\text { تكنولوجيا التعليم ، الكتاب الثالث . }
$$

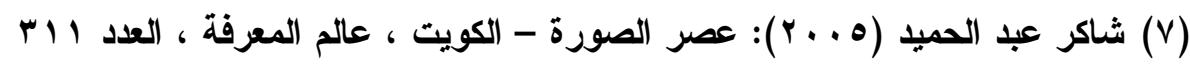

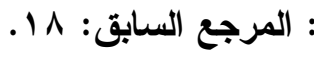

$$
\begin{aligned}
& \text { : المرجع السابق: ه } 10 \text { ، ، ب. }
\end{aligned}
$$

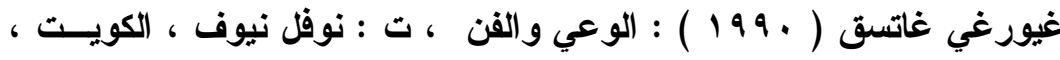

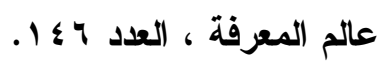

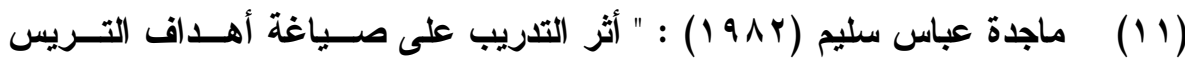

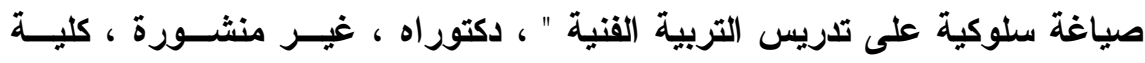

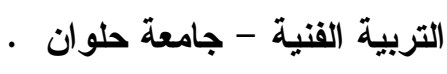

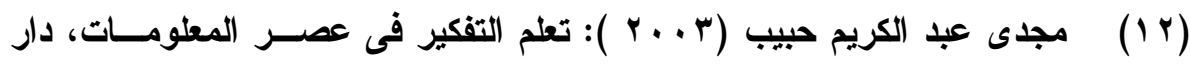

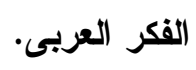

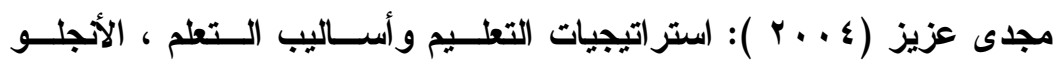

محمد عبد الكريم الأحمد (1911) : " أثر تزويد الصــف الثالــث الإعـــادي

بالأهداف السلوكية في تحصيلهم الرياضيات " ، ماجستير الأردن - جامعة اليرموك. 


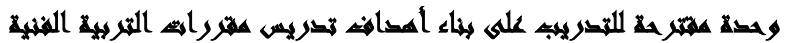

(10) محد محمد الدسوقى (911 1) ): برنامج تدريبى لممارسة التصوير ، دكتــوراه

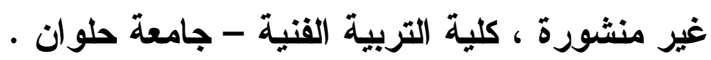

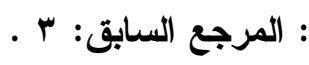

$$
\begin{aligned}
& \text { : المرجع السابق: rیr ـ ـ }
\end{aligned}
$$

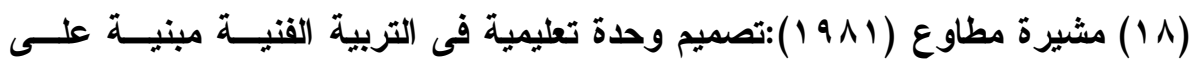

طريقة تعلم المفاهيم، رسالة ماجستير غير منشورة ، كلية التربية الفنية - جامعـة ولئة

$$
\text { حلوان. }
$$

نهاد موسى القلماوى (Y991 (1) : تصميم معيار لقياس نمو العملية التعليميـة

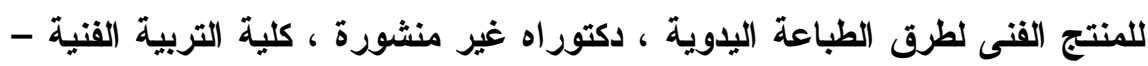

$$
\text { جامعة حلوان }
$$

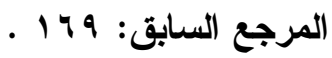

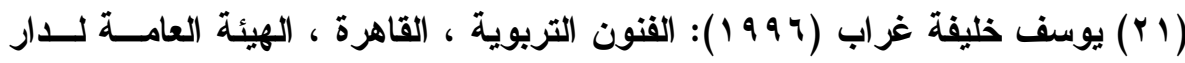

$$
\text { الكتب و الوثائق }
$$

(22) Arnon, U . (1981) : A Toxonomy Mental operational Functions . State university college at Baffalo art Education department.

(23) Bloom , B.S. et al . ( 1979 ) : Hand book on formative and summative evaluation of student learning new york, Me. - Grew - Hill, U.S.A.

(24) Doty C.R. the effect of practice and prior knowledge of education objective in performance unpublished. D. of Diss. The ohia state U. et al. Ohia . 1968 . 